HELENA LARSSON EXISTENTIELL ENSAMHET HOS SKÖRA ÄLDRE PERSONER: ETT NÄRSTÅENDEPERSPEKTIV

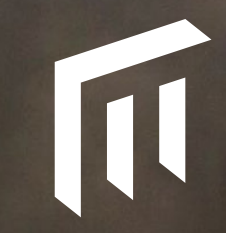



EXISTENTIELL ENSAMHET HOS SKÖRA ÄLDRE PERSONER:

ETT NÄRSTÅENDEPERSPEKTIV 
Malmö universitet, Fakulteten för hälsa och samhälle Institutionen för vårdvetenskap Doktorsavhandling 2020: 1

(C) Helena Larsson 2020

Cover: (C) Mattias Larsson Cinematography

ISBN 978-9I-7877-06I-8 (tryckt)

ISBN 978-9I-7877-062-5 (pdf)

ISSN $1653-5383$

DOI I 0.24834 isbn.9789I78770625

ISBN 978-9I-87973-46-8 Högskolan Kristianstad

Holmbergs, Malmö 2020 


\section{HELENA LARSSON}

\section{EXISTENTIELL ENSAMHET HOS SKÖRA ÄLDRE PERSONER: ETT NÄRSTÅENDEPERSPEKTIV}

Malmö universitet, 2020 Fakulteten för hälsa och samhälle

Högskolan Kristianstad, 2020 Fakulteten för hälsovetenskap 
Publikationen finns även elektroniskt:

http://dspace.mah.se/handle/2043/30658 
Till Henrik, Viktor, Ebba och Vera 



\section{INNEHÅLL}

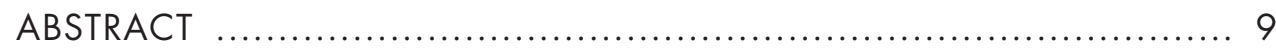

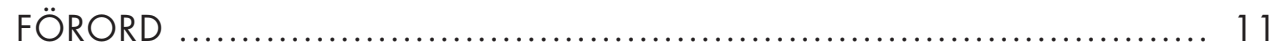

ORIGINALARTIKLAR ................................................. 13

DEFINITIONER OCH FÖRKORTNINGAR .............................. 14

INTRODUKTION ...................................................... 16

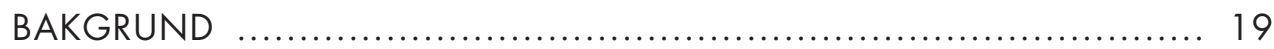

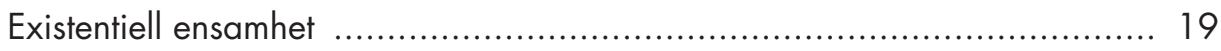

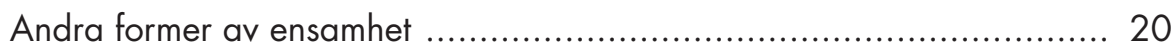

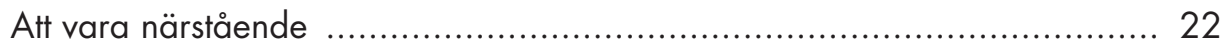

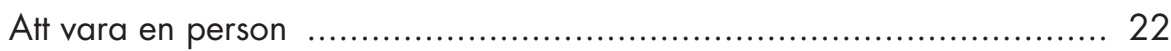

Att vara närstående till en skör äldre person ................................... 23

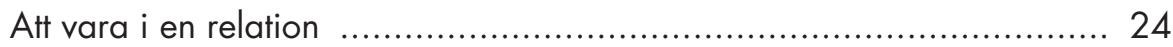

Att förhålla sig till en vårdande roll .................................................. 26

Behov av stöd och anhörigkonsulentens funktion ................................. 28

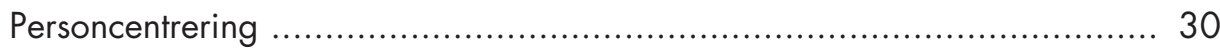

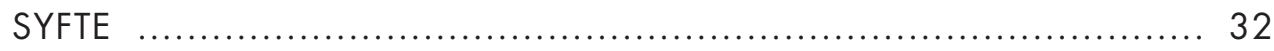

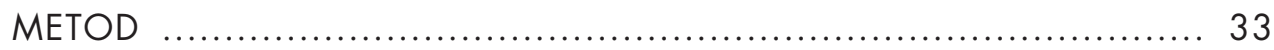

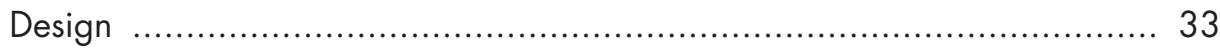

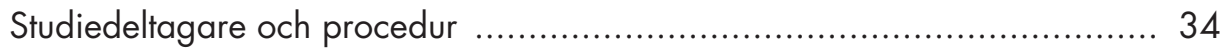

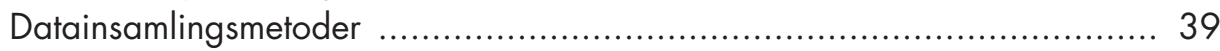

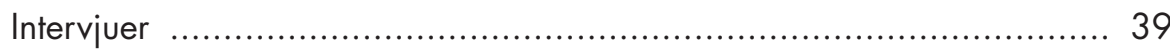

Fältanteckningar ............................................................ 42

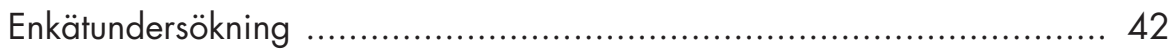

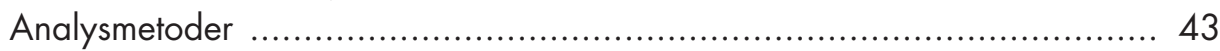

Hermeneutisk analys ............................................................ 43

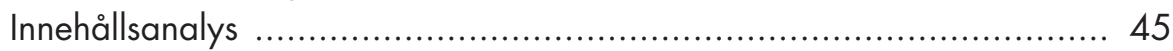

Fallstudie med tematisk analys ..................................................... 46 
Beskrivande statistisk analys ....................................................... 47

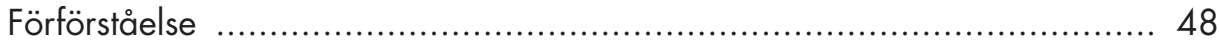

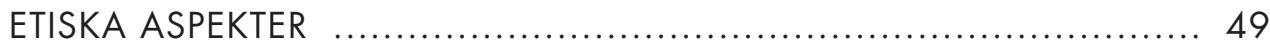

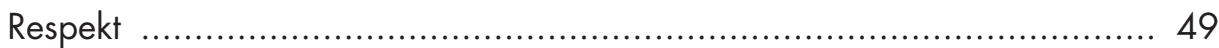

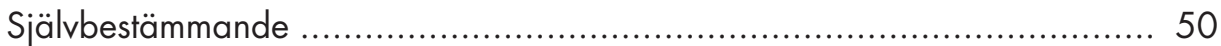

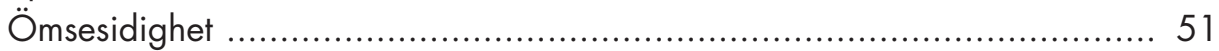

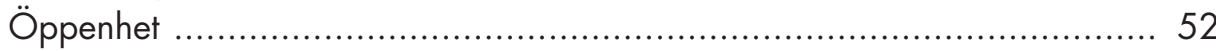

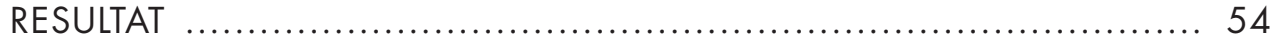

Att sakna, men också sträva efter djupare samhörighet ........................... 54

Stöd i strävan efter samhörighet ................................................ 55

Att vara i, men också uthärda en oönskad separation ............................. 56

Stöd i en oönskad separation ........................................................ 58

Att inte finna, men ändå försöka återskapa mening .............................. 59

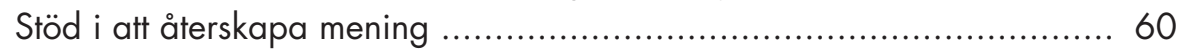

METODOLOGISKA ÖVERVÄGANDEN ............................... 62

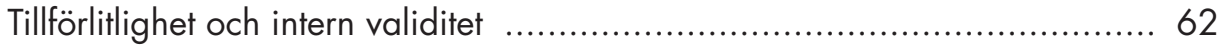

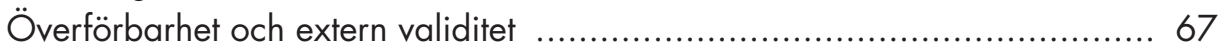

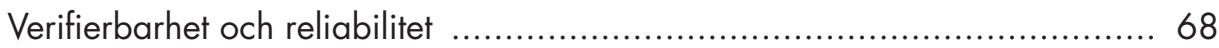

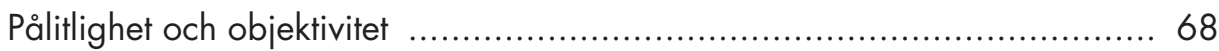

DISKUSSION …...................................................... 70

Att balansera mellan det som var och det som ska bli ............................ 70

Att längta efter gemenskap och förankring .......................................... 72

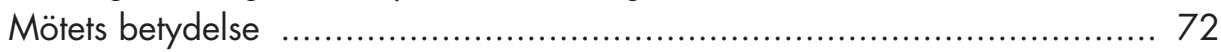

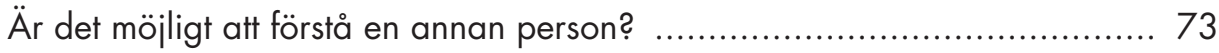

Personcentrering - ett förhållningssätt ................................................ 75

SLUTSATSER OCH KLINISK BETYDELSE ............................... 78

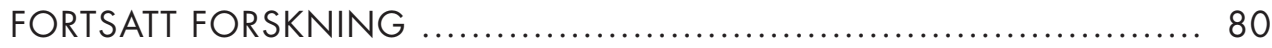

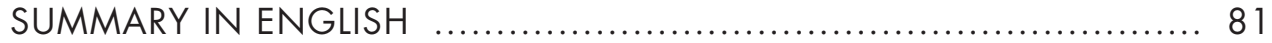

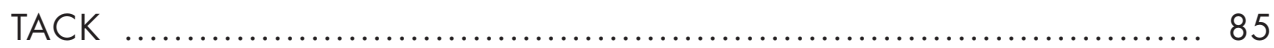

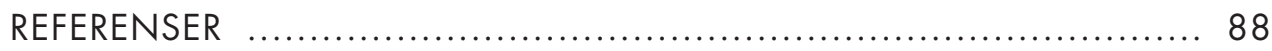

APPENDIX I. [ENKÄT] _............................................... 97

ARTIKLAR I-IV ........................................................ 99 


\section{ABSTRACT}

The aim of this thesis was to explore existential loneliness from the perspective of significant others, to contrast their perceptions with frail older people's experiences and to describe significant others' and family care advisors' views on existential support. This thesis is part of a larger research project about existential loneliness among frail older people, the LONE study. The thesis embraces three qualitative and one quantitative study. A total of 29 significant others, 15 frail older people and 120 family care advisors participated in the studies. The significant others were husbands, wives, daughters, sons, other relatives and friends to frail older people. The concept 'frail older people' was defined as older persons ( $\geq 75$ years old) dependent on long-term health- or social care. The qualitative studies were based on multistage focus-group interviews (study I) and individual interviews (studies II and III). The quantitative study (IV) had a cross-sectional design and was based on a questionnaire specifically developed for the current study. Different methods to analyse data were used; hermeneutics (study I), content analysis (study II), a case study with thematic analysis (study III) and descriptive statistics (study IV). Findings from the four studies show that existential loneliness emerges when: 1) Longing for, but also striving for, a deeper feeling of connectedness, 2) Being in, but also enduring, an unwanted separation, and 3) Not finding, but still trying to recreate meaning. This thesis also shows that existential loneliness is often experienced in so-called limit situations in life and arises in difficult choices related to close relationships, in connection with experiences of meaninglessness and in the absence of connection to something or someone. The results show that existential loneliness emerges in the process of balancing between what was and what is to come in the unknown future. Significant others navigate themselves, and sometimes together with the older person, through an unfamiliar existence that makes them feel ambivalent about the de- 
cisions they have previously made and the decisions they need to make in the future, while also doubting the meaning in their current situation. Existential support should mainly focus on transition phases and on relational aspects. Person-centredness can be a way to make the existential needs of significant others and older people visible and to provide support based on their needs. 


\section{FÖRORD}

Som nyexaminerad sjuksköterska inledde jag mitt arbete vid en geriatrisk vårdavdelning vid Dalens sjukhus i Stockholm. Jag fick möta äldre personer med skiftande livssituation, behov och önskemål. Min väg ledde vidare till arbete vid en enhet inom specialiserad palliativ vård. Åren gav mig erfarenhet av möten med svårt sjuka personer i livets slutskede, men även med deras närstående. Samtalen, både bland oss som vårdpersonal och med personerna som vi vårdade och deras närstående, berörde ofta djupa frågor om livet, mening, döende och död. Erfarenheterna ledde vidare till ett intresse för att studera dessa frågor vidare.

Vid inledningen av mina doktorandstudier hade jag ingen direkt kunskap om eller förståelse för, vad existentiell ensamhet var. Jag kunde ana att det handlade om en slags djupare, inneboende känsla av ensamhet, men inte mer än så. Som så mycket annat är sådant som är oklart för mig också det som är mest intressant att ta reda på mer om, särskilt när det är något som jag inser att andra människor också funderar över men faktiskt inte heller riktigt vet vad det är. Jag började fråga människor i min omgivning om de visste vad existentiell ensamhet var. Några började trevande förklara medan andra sa att det där lät intressant, men är det något som finns och vad är det i så fall. Så inleddes min väg in i detta filosofiska landskap.

Så här några år senare är jag medveten om att existentiell ensamhet inte låter sig förklaras eller avgränsas så enkelt. Existentiell ensamhet upplevs och kommuniceras på olika sätt, förmodligen för att vi som människor är olika, bär på olika erfarenheter och klär våra upplevelser och tankar i olika ord och uttryckssätt. I den här avhandlingen beskriver jag några av de situationer och uttryckssätt som jag har funnit som 
handlar om existentiell ensamhet. På senare tid har jag haft möjlighet att vistas i författaren Artur Lundkvists stuga i Hagstad. I en av hans böcker finns nedanstående rader som säger något om ensamhetens dimensioner.

Jaget är ensamt, menar diktaren, men dess ensamhet är befolkad.

I ett myller av människoöden rör sig människan, alltid ensam, aldrig allena.

ur 'En befolkad ensamhet' av Artur Lundkvist 


\section{ORIGINALARTIKLAR}

Avhandlingen baseras på följande studier som refereras till med romerska siffror i texten:

I Larsson, H., Rämgård, M., Kumlien, C., \& Blomqvist, K. Spouses' existential loneliness when caring for a frail partner late in life - A hermeneutical approach. Inskickad till tidskrift.

II

Larsson, H., Rämgård, M., \& Bolmsjö, I. (2017). Older persons' existential loneliness, as interpreted by their significant others - an interview study. BMC Geriatrics, 17, 138.

III

Larsson, H., Edberg, A-K., Bolmsjö, I., \& Rämgård, M. (2019). Contrasts in older persons' experiences and significant others' perceptions of existential loneliness. Nursing Ethics, 26(6), 1623-1637.

IV

Larsson, H., Blomqvist, K., Edberg, A-K., \& Kumlien, C. Family care advisors' views on existential loneliness and existential support provided to informal caregivers to older people. Manuskript.

Tillåtelse att trycka artiklarna i sin helhet i avhandlingen har erhållits av respektive utgivare. Redogörelse av insats i publikationerna: För delstudie II och III fanns design planerad inom ramen för LONE-studien medan design för studie I och IV planerades av mig tillsammans med respektive medförfattare. Jag har genomfört datainsamling, analyserat material och skrivit resultat och manus i samtliga fyra delstudier i samarbete med medförfattare för respektive publikation. 


\section{DEFINITIONER OCH FÖRKORTNINGAR}

Skör äldre person

Närstående

Anhörigkonsulent

LONE-studien

Informell vård

Formell vård
I den här avhandlingen avses en person som är 75 år och äldre samt $\mathrm{i}$ behov av varaktig vård och omsorg från hemtjänst/hemsjukvård, särskilt boende, primärvård, palliativ vård eller sjukhusvård.

I den här avhandlingen används begreppet närstående för att benämna en person som står den sköra äldre personen nära, antingen genom släktskap, som partner eller som god vän.

En person som är anställd av en kommun och vars verksamhet riktar sig till personer som hjälper, stödjer eller vårdar en släkting eller vän.

Avhandlingen är en del av ett större forskningsprojekt som förkortas 'LONE-studien'. Bokstäverna 'LON' står för loneliness (ensamhet) och 'E' står för existential (existentiell).

Vård, stöd och hjälp som ges av partner, släktingar och vänner utan ekonomisk ersättning.

Vård som ges av hälso- och sjukvårdspersonal. 
Nka

Nationellt kompetenscentrum anhöriga, startades 2008 med syfte att synliggöra anhörigas situation. Uppdraget innefattar att utveckla stöd till anhöriga.

HSL

Hälso- och Sjukvårdslagen

SoL

Socialtjänstlagen 


\section{INTRODUKTION}

En positiv utveckling, världen över, är att människor lever allt längre liv (WHO, 2019). Samtidigt medför utvecklingen att samhällen ställs inför andra utmaningar än tidigare generationer har gjort. En nutida utmaning är ensamhet som internationellt beskrivs som ett ökande folkhälsoproblem, särskilt i västerländska samhällen som är präglade av ett individualistiskt synsätt snarare än ett kollektivistiskt synsätt (Nyqvist, Victor, Forsman \& Cattan, 2016). Ensamhet tenderar att beskrivas enbart som ett och samma tillstånd, trots att litteratur och forskning menar att ensamhet kan anta flera olika former som både har likheter och olikheter mellan varandra (Tornstam, 1978/2018). Ensamhet har både positiv och negativ klang, beroende på sammanhang och individuella omständigheter. När ensamheten är efterlängtad och önskad är den positiv men när vi känner oss ensamma och utanför blir ensamheten negativ. Den existentiella dimensionen av ensamhet, existentiell ensamhet, verkar framför allt framträda i utsatta situationer, vid upplevd sårbarhet och i övergångsfaser i livet och beskrivs som en djup form av ensamhet (Yalom, 1980; Bolmsjö, Tengland \& Rämgård, 2018). Trots att existentiell ensamhet anses vara en upplevelse som tillhör mänskligt liv (Yalom, 1980) har få empiriska studier gjorts (Ettema, Derksen \& van Leeuwen, 2010) och kunskap saknas om hur denna form av ensamhet upplevs, uppfattas och kommuniceras.

Existentiella behov och existentiell ensamhet verkar starkt sammankopplade med att livet går mot sitt slut och känslan av meningslöshet uppstår. De existentiella frågorna blir allt mer centrala under åldrandet (van Wijngaarden, Leget \& Goossensen, 2015; Sjöberg, Beck, Rasmussen \& Edberg, 2018). Närstående är ofta de som möter äldre personer och ser deras existentiella behov. Socialstyrelsens lägesrapport (2019a) visar att allt fler hjälper och stödjer någon i sin närhet som är äldre. Att ge 
en annan person hjälp och stöd ger tillfredsställelse och känslor av att kunna bidra men det kan också leda till egen ohälsa (Greenwood \& Smith, 2016), utmattning, stress och isolering (Stoltz, Udén \& Willman, 2004). För att orka vara den som ger hjälp och stöd behövs det också hjälp och stöd. Oftast nämns fysiskt och socialt stöd eller praktiskt stöd (Hellström, Sandberg, Hanson \& Öhlén, 2017) men sällan nämns existentiellt stöd. Enligt lag (SoL 2001:453) är varje kommun i Sverige ålagd att ge stöd till närstående som hjälper och stödjer äldre personer. Vad detta stöd innebär, särskilt avseende existentiella behov, är sparsamt beskrivet.

För att uppmärksamma och möta existentiella behov behöver de synliggöras. Ett förhållningssätt är personcentrering som handlar om strävan efter att varje person ska bli sedd i sitt sammanhang och mött utifrån sina behov och önskemål (Dewing, Eide \& McCormack, 2017). En litteraturstudie med fokus på personcentrering inom vård av äldre lyfter fram betydelsen av att se till hela sammanhanget, där den äldre personen med sina betydelsefulla relationer är utgångspunkten för vården som ges (McCormack, 2004). Att involvera närstående i vården av sköra äldre personer och lyssna till dem har betydelse för hur vården upplevs (Søvde, Hovland, Ullebust \& Råholm, 2019). I begreppet att vara närstående finns underförstått ett budskap om att vara i relation till en annan person. För att kunna lindra lidande och öka välbefinnande för närstående, behövs forskning om, och i så fall hur, existentiell ensamhet påverkar den som lever med en person som är skör och äldre. Närstående är många gånger de som tolkar vad äldre personer ger uttryck för och förmedlar detta vidare till vårdpersonal och därför är det betydelsefullt att få kunskap om $i$ vilken mån närståendes uppfattningar överensstämmer med den äldres upplevelser. Beroende på vems röst som vanligen ges företräde $i$ vården är kunskap om skillnader i upplevelser och uppfattningar angelägen. Avhandlingen har fokus på ett närståendeperspektiv i relation till existentiell ensamhet hos sköra äldre personer. Studierna omfattar närståendes egna upplevelser av existentiell ensamhet, deras uppfattningar om äldre personers existentiella ensamhet, samt kontrasterna mellan närståendes uppfattningar och äldre personers upplevelser. Avhandlingen innefattar också en undersökning av anhörigkonsulenters syn på existentiell ensamhet och existentiellt stöd, se figur 1. 


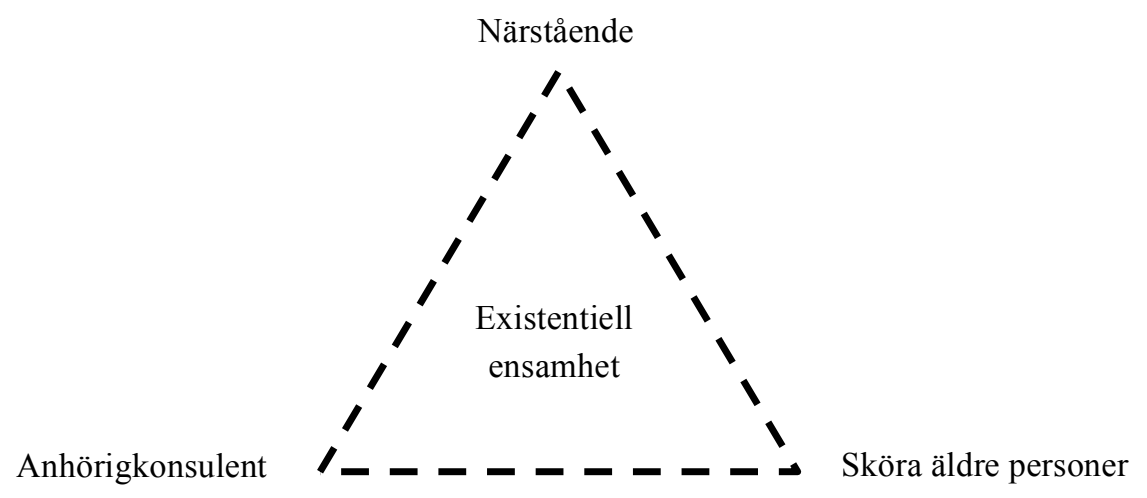

Figur 1. Centrala perspektiv i den här avhandlingen. 


\section{BAKGRUND}

\section{Existentiell ensamhet}

Existentiell ensamhet beskrivs av existenspsykologen Irvin Yalom (1980) som en djup form av ensamhet, som ett av livets villkor och som en del av att vara människa. Han menar att livet innehåller skeden då vi möter existentiell ensamhet. Skedena benämns som the ultimate concerns och handlar om den oundvikliga döden, vårt behov av frihet, vårt behov av att känna gemenskap och samhörighet, och sökandet efter mening. Att konfrontera och möta sådana skeden i livet är oundvikligt (Yalom, 1980).

Existentiell ensamhet har studerats i litteraturstudier. I Mayers och Svartbergs (2001) studie sammanställs tre olika aspekter avseende existentiell ensamhet; litteratur, möjliga mätinstrument samt utlösande faktorer för existentiell ensamhet hos kvinnor med HIV. Mayers och Svartberg (2001) beskriver existentiell ensamhet som en grundläggande känsla av ensamhet, och i likhet med Yalom (1980), som en känsla som inte går att undgå genom livet. De beskriver också existentiell ensamhet som en upplevelse som är sammanflätad, dels med andra former av ensamhet och dels med andra upplevelser som ångest och meningslöshet (Mayers \& Svartberg, 2001). En annan litteraturstudie av Ettema et al. (2010) är systematisk och beskriver existentiell ensamhet som en upplevelse och som en process som kan leda till något positivt av att växa som människa, intellektuellt och själsligt. Existentiell ensamhet verkar framträda när vi som människor inser att vi är ensamma i världen, trots att det finns människor i vår närhet (Moustakas, 1961; Yalom, 1980; Mayers \& Svartberg, 2001; Ettema et al., 2010). Applebaum (1978) beskriver att olika former av ensamhet hör samman med varandra och att en av dessa former är existentiell ensamhet. Enligt Applebaum utmärks existentiell ensamhet av att den uppkommer i övergångsfaser i livet. Ett fåtal empiriska studier är genomförda inom hälso- och sjukvården 
och visar att existentiell ensamhet uppstår vid utsatta situationer. Exempel på utsatthet är när en person drabbas av afasi efter en stroke, det vill säga förlorar sin förmåga att kommunicera verbalt (Nyström, 2006), lever med HIV (Mayers \& Svartberg, 2001) eller är i livets slutskede (Sand \& Strang, 2006). Däremot har inga studier med närståendeperspektiv identifierats.

En senare begreppsanalys (Bolmsjö et al., 2018) beskriver existentiell ensamhet som en omedelbar och ögonblicklig medvetenhet om att jag som människa är fundamentalt ensam, separerad från andra människor. Denna medvetenhet framträder framför allt i stunder då människan inser sin egen dödlighet eller vid kriser, särskilt om man inte känner sig sedd eller mött i sin situation. Som en följd av denna medvetenhet upplevs känslor som sorg, hopplöshet, ångest och meningslöshet (a.a.). En av studierna i begreppsanalysen är en kvalitativ studie om innebörden av existentiell ensamhet hos sköra äldre personer (Sjöberg et al., 2018). Studien visar att äldre personers existentiella ensamhet hörde samman med att känna sig fångad i en skör kropp, att mötas av likgiltighet, att inte ha någon att dela livet med och att sakna mål och mening i livet.

En nyligen publicerad sammanställning av 144 kvalitativa studier om ensamhet beskriver tre riktningar; social ensamhet, emotionell ensamhet och existentiell ensamhet. Existentiell ensamhet sammanfattas som en form av ensamhet som framträder, framför allt, när människor konfronteras med livshotande sjukdom, trauman, döende och död (Mansfield et al., 2019).

\section{Andra former av ensamhet}

Ensamhet benämns ibland som en upplevelse eller ett tillstånd men ensamhet är snarare ett begrepp som kan anta flera olika former (Tornstam, 1978/2018). Ensamhet beskrivs emellanåt, i negativa ordalag, som allt mer förekommande i Europa (Hombres, Schnepf, Barjakova \& Teixeira Mendonca, 2018) medan Tornstam (1978/2018) menar att ensamhet har minskat. Socialstyrelsen (2019b) redovisar att förekomsten av ensamhet bland äldre personer i Sverige har legat förhållandevis konstant de senaste åren. Ensamhet beskrivs i vissa sammanhang som ett känsligt ämne att samtala om eftersom den kan förknippas med känslor av skuld och skam (Smith, 2012). Undersökningar har gjorts av Socialstyrelsen (2019b) om vad äldre personer anser om äldreomsorgen där det framkom att 40 procent av äldre som bor i ordinärt boende med stöd av hemtjänst besväras av ofrivillig ensamhet. Av dem som 
bor på särskilt boende är motsvarande siffra 47 procent, alltså något högre trots närhet till vårdpersonal och medboende.

Ensamhet beskrivs som en tudelad känsla med både positiv och negativ innebörd, som på engelska är två olika ord; loneliness och solitude (Ettema et al., 2010; Graneheim \& Lundman, 2010). Ensamhet (loneliness) som en negativ känsla upplevs i längtan efter mänsklig kontakt och beskrivs ofta med uttryck som ledsamhet, oro, ängslan (Moustakas, 1961; Perlman \& Peplau, 1998). Ensamhet kan vara en smärtsam känsla som sätts igång av förlust av vänner och familj, känslan av att vara övergiven, inte vara betydelsefull eller av att inte vara sedd (Ettema et al., 2010; Graneheim \& Lundman, 2010; Taube, Jakobsson, Midlöv \& Kristensson, 2016). Ensamhet kan också vara självvald (solitude) och därmed vara önskad och rofylld (Ettema et al., 2010; Graneheim \& Lundman, 2010). I Broströms (2014) avhandling som är en monografi om äldre personers föreställningar om framtiden, beskrivs exempelvis äldre personer som ville vara ensamma, fick möjlighet att ta dagen som den kom och som hade en trygg förankring i sitt hem. Ibland används även det engelska begreppet alienation som en beskrivning av ensamhet. Alienation handlar om en djup känsla av utanförskap och främlingskap, både i förhållande till andra människor och/eller till omgivningen (Stokols, 1975).

Ensamhet kan vidare handla om social ensamhet, emotionell ensamhet och/eller fysisk ensamhet. Social ensamhet beskrivs som en längtan efter gemenskap med andra människor (Weiss, 1987; Perlman \& Peplau, 1998) och kan bli framträdande vid förlust av vänner, familj, partner eller arbete (Broström, 2014; Dahlberg, 2007). Strang (2014) lyfter fram att vi är skapade för gemenskap och att vi har en utmaning i en individualistisk värld, i västvärlden, som krockar med det grundläggande behovet hos varje människa att få känna tillhörighet och gemenskap. Emotionell ensamhet beskrivs som känslan av ensamhet trots människor i närheten eller när det inte går att dela sina tankar med någon annan människa (Weiss, 1987). Därtill inverkar kultur och miljö på upplevelsen av social och emotionell ensamhet (Sønderby \& Wagoner, 2013). Fysisk ensamhet handlar om längtan efter fysisk beröring och närhet och om detta behov inte blir tillgodosett upplevs en fysisk ensamhet (Sand \& Strang, 2006). De olika ensamheterna hör ofta samman och kan vara överlappande, till exempel social och fysisk ensamhet; finns det ingen kvar är det svårt att vara "fysisk" med någon. 
Ytterligare en form av ensamhet som nämns i litteratur och som ligger nära existentiell ensamhet, är den ensamhet som i det engelska språket benämns som isolation. Tre former av isolation beskrivs (Yalom, 1980). Den första benämns som interpersonal isolation och handlar om en generell upplevelse av att känna sig ensam och utanför. Den andra formen kallas intrapersonal isolation och är en inre ensamhet oavsett om det finns människor nära, eller inte. Den tredje formen av isolation benämns som existential isolation och beskrivs som en medvetenhet om att människan är ensam, separerad från andra människor (Yalom, 1980; Ettema et al., 2010). Pinel, Long, Murdoch och Helm (2017) sammanfattar existential isolation som att känna sig ensam i sin upplevelse, som att ingen förstår eller uppfattar omvärlden på ett liknande sätt som jag själv. Yalom (1980) beskriver existential isolation som en dal av ensamhet som har flera dimensioner. Att möta svåra skeden i livet såsom döende och begränsad frihet är två aspekter som oundvikligen leder människan till denna dal av ensamhet. Således finns det flera former av ensamhet som både har likheter och olikheter mellan varandra. Denna avhandling har fokus på existentiell ensamhet.

\section{Att vara närstående}

Begreppen närstående, anhörig eller familj används oftast $i$ ett vårdsammanhang för att benämna en person som vårdar eller stödjer en annan person. Enligt Socialstyrelsens termbank (2019) syftar begreppet anhörig på en person inom den närmaste familjen eller bland de närmaste släktingarna. Begreppet närstående syftar på "personer som den enskilde anser sig ha en nära relation till”. Således kan begreppet närstående även innefatta en vän eller en granne och kan därför användas i en vidare betydelse än begreppet anhörig. Närstående används i den här avhandlingen som ett samlingsbegrepp för den eller de som står den äldre personen nära oavsett om det är en partner, en vän eller en släkting.

\section{Att vara en person}

Att vara närstående är att vara en person. I en svensk kontext har begreppet "person" allt mer uppmärksammats de senaste 20 åren. Kristensson Uggla (2014), professor i filosofi, är en av dem som har riktat ljuset mot vad det innebär att vara en person. Han lutar sig mot filosofer såsom Paul Riceour och belyser att vara en person handlar om att tala om vem en person är snarare än om vad en person är. För att veta något om vem en person är blir personens berättelse central. Det som formar en människas berättelse är hennes tanke och förställningar. När en person berättar om sig själv blir det möjligt att förstå något om det som gör en människa till en person. En väsentlig aspekt är dock att det inte finns endast en berättelse utan varje person bär 
på flera berättelser som tillsammans kan forma vem personen är. Att vara en person innebär att existera som människa, ha relationella band med sin omgivning, ha förmågor som att kunna reflektera över sitt liv, sina val, sina handlingar och sina värderingar (Kristensson Uggla, 2014).

Vem jag är som person handlar om vad jag tänker om mig själv och hur jag ser på min identitet, det vill säga hur jag ser på min existens. Filosofer har genom flera århundraden försökt sätta ord på vad det är att existera. En av dem är Viktor Frankl (1946/2006) som talar om en människas existens med hjälp av tre dimensioner. Första dimensionen är det fysiska livet, alltså att finnas till vilket kanske är den dimension som är enklast att tala om eftersom den är konkret och synlig för ögat. Andra dimensionen handlar om existensens mening, varför vi lever. Tredje dimensionen handlar om en egen personlig strävan efter mening, varför vi vill leva. Frankl (1946/2006) menar att dimensionerna går in i varandra och inte kan särskiljas. Det handlar alltså om essensen, det vill säga hela upplevelsen av att existera. Människans existens kan också handla om tankar som hör samman med andlighet. Melder (2011) beskriver att andlighet och existentialism relaterar till en inre dimension som blir synlig i interaktion med omgivningen (a.a.). När existensen, oavsett dimension, är hotad eller skadad kan ett existentiellt lidande uppkomma (Sand \& Strang, 2013). Ett sådant exempel ges i en studie av Nyström (2006) som handlar om personer som drabbats av afasi och till följd av det upplever ett existentiellt lidande. Tankar om människans existens innefattar alltså de existentiella frågor som varje människa möter genom livet som handlar om meningen med livet, om val, om frihet och om döden. Tankar som formar vem jag är som person.

\section{Att vara närstående till en skör äldre person}

Att vara en person innebär att leva i relation med sin omgivning där denna avhandling fokuserar på närstående till sköra äldre personer. Det finns föreställningar om hur det är att åldras och vad åldrandet innebär. Det finns yttre föreställningar från samhället och/eller inre förställningar som kommer från personen själv. Ibland målas det upp en ganska dyster bild av åldrandet som en tid i livet som är kantad av sjukdom, förluster och ensamhet. Tornstam (1978/2018) som var svensk professor i sociologi, pekar på några av dessa föreställningar som handlar om att samhället anser att äldre personer helst vill vara för sig själva, är svaga, sjuka och ensamma. Ibland tenderar den bilden att bli rådande i samhällsdebatten, i planeringen av vård och som samhällsstruktur (Magnusson, 2014). Dessa föreställningar kan också komma från personen själv som inre förställningar om hur åldrandet är eller ska bli. 
Tornstam (1978/2018) utmanar dessa föreställningar och menar att åldrandet har sin alldeles egna mening och karaktär, att den är en egen del av livet snarare än en fortsättning på medelåldern.

Det finns många olika teorier om åldrandet och en sådan är Tornstams (1978/2018) teori om gerotranscendens som handlar om att livet ses som en process som innesluter alla erfarenheter som gjorts under livet. Processen beskrivs inte som statisk eller linjär utan snarare som ett kontinuum som både kan bromsas upp eller påskyndas beroende på yttre omständigheter såsom sjukdom eller förluster (Tornstam, 1978/2018). Oftast innebär gerotranscendens en omvärdering av tid, rum, liv och död. Saker som varit viktiga tidigare i livet blir kanske mindre viktiga och sådant som inte tagit plats förut blir allt viktigare. Den sista delen av livet kan också beskrivas med hjälp av makarna Erik och Joan Eriksons (Erikson, 1982/1997) teori om människans utveckling. Teorin delar in livet $\mathrm{i}$ åtta åldrar för att karakterisera människans utveckling genom livet. Ett nionde steg lades till av Joan, efter Eriks död. Teorin beskriver det nionde steget, livets sista del, som att vara i en balansgång mellan att känna mod men på samma gång modlöshet, känna tilltro men på samma gång misstro, känna skam och skuld men på samma gång styrka och beslutsamhet (a.a.).

\section{Skörhet}

I balansgången som Erikson (1982/1997) talar om finns skörhet. Skörhet kan bottna i en åldrande fysisk kropp som leder till beroende av andra människor för att klara av vardagen. Skörheten kan också leda till identitetskris och tvivel: "Vem är jag när jag inte längre kan?" (Fillit \& Butler, 2009). Att uppmärksamma och konkretisera vad skörhet innebär är av betydelse för att möta en person som är skör, oavsett om det är fysiskt, psykiskt eller socialt (Stow, Spiers, Matthews \& Hanratty, 2019). Ett begrepp som ligger nära skörhet är sårbarhet. Kristensson Uggla (2014) belyser åldrandet utifrån att vara kapabel och sårbar, två begrepp som särskilt hamnar i fokus när kroppen åldras och blir skör. Att vara både kapabel och sårbar tillhör mänskligt liv men hur det kommer till uttryck varierar genom livet. Genom hela livet är vi både kapabla och sårbara, kapabla att fatta beslut och göra val, sårbara genom att leva i relation till och med omgivningen i ett beroende av varandra.

\section{Att vara i en relation}

I denna avhandling är relationen mellan närstående och sköra äldre personer central. Filosofer, däribland Martin Buber (1923/2013), menar att relationen är central för människans existens och att livets mening handlar om mötet mellan dig och mig. 
Buber beskriver relationer med orden "jag", "du" och "det". När relationer består av möten mellan "jag" och "du" finns förutsättning för goda och givande möten mellan människor. I en sådan relation är jag intresserad av dig, och du är intresserad av mig. Men, i möten där "du" istället blir till ett "det", det vill säga till ett objekt snarare än ett subjekt, går relationen förlorad. Ett genuint möte uppstår när det är möjligt att dela sådant som är viktigt (Buber, 1923/2008; 1923/2013). Om vi som människor inte har, eller inte kan upprätthålla, relationer där genuina möten sker med möjlighet att dela livets väsentligheter, som till exempel vid åldrande och kroppslig skörhet, kan livets mening gå förlorad. Därför är det livsavgörande för människans existens att känna att det finns ett genuint intresse för varandra (Buber, 1923/2008; 1923/2013). Kvalitativa studier från både Sverige och andra västerländska länder visar att många närstående strävar efter att upprätthålla en relation med den äldre personen, särskilt när den äldre till exempel flyttar till ett äldreboende (Russel \& Foreman, 2002; Whitaker, 2009).

I en relation finns det olika roller. Bergum och Dossetor (2005) menar att vara närstående till en äldre skör person innebär dels att vara ett vittne, dels att vara beslutsfattare. Ett vittne är den som "vet något" och en beslutsfattare är den som "fattar beslut". Vi kan inte veta om närstående vet vad den äldre personen önskar eller vill och inte heller på vilka grunder de närstående tar beslut. Bergum och Dossetor (2005) och Tengland (2008) påtalar vikten av att följa någon nära och vara intresserad för att förstå vad den andre vill och önskar. För förståelse krävs samtal om viktiga saker, först då är det möjligt att veta vad någon vill eller behöver (Buber, 1923/2008). Norell Pejner, Ziegert och Kihlgren (2015) beskriver att äldre personer ofta söker känslomässigt stöd hos sina närstående och att de vill ha dem nära.

Relationen mellan närstående och den äldre personen har betydelse, dels eftersom närstående ofta är den som tolkar signaler som sköra äldre personer ger uttryck för, dels eftersom närstående förmedlar dessa signaler vidare till vårdpersonal. Ett exempel på hur detta ofta görs är proxyskattningar (jfr ombud, fullmakt) som blivit allt vanligare de senaste åren. Proxyskattningar innebär att någon annan, till exempel närstående eller vårdpersonal, skattar äldre personers symtom eller livskvalitet. Studier visar att det finns skillnader när skattningar som gjorts av äldre själva jämfört med de som gjorts av andra, till exempel avseende smärta (Lukas, Niederecker, Günther, Mayer \& Nikolaus, 2013) eller livskvalitet bland personer med demenssjukdom (Robertson et al., 2017). Det verkar vara så att även personer, som känner den äldre personen väl, kan ha svårigheter att till fullo uppfatta vad den äldre uttrycker. 


\section{Att förhålla sig till en vårdande roll}

Relationen mellan närstående och sköra äldre personer handlar också om att förhålla sig till en vårdande roll. Närstående beskrivs som en viktig hjälp för äldre personer, som för talan i deras ställe, när de äldre inte längre själva kan eller vill (Dyrstad, Laugaland \& Storm, 2015; Abrahamsson, Bernard, Magnabosco, Nazir \& Unroe, 2016) och vårdpersonal vänder sig många gånger till närstående när de behöver information om den som de vårdar (Caspari et al., 2014). Men närstående själva befinner sig många gånger i en komplex situation. Enligt Socialstyrelsens lägesrapport för Äldreomsorgen (2019a) är närstående som är mellan 65 och 80 år, de som har det största åtagandet och ger mest tid till någon i sin närhet som är i behov av hjälp eller stöd. Det handlar oftast om att ge stöd och hjälp till den personen som man lever tillsammans med, det vill säga i de flesta fall till sin partner. Det handlar om att både sköta hemmet och om att hjälpa sin partner med personlig omvårdnad. Närstående beskrivs som experter på den andres tillstånd och som beskyddare (James, Andershed \& Ternestedt, 2009) men situationen har många gånger konsekvenser för deras egen hälsa och välbefinnande (Erlingsson, Magnusson \& Hanson, 2012; Wester, Larsson, Olofsson \& Pennbrant, 2013). En litteraturstudie från Storbritannien visar att närstående över 75 år som vårdar någon i sin närhet upplever att det är svårt när de känner sig ensamma och har egna hälsoproblem, men på samma gång tillfredsställande när de känner sig uppmuntrade av vårdpersonal (Greenwood \& Smith, 2016). En kvantitativ studie visar att 115 av 176 äldre informella vårdare upplever utmattning såväl fysiskt som socialt och emotionellt, i samband med vård av någon som står dem nära (Neri et al., 2012).

En emotionellt krävande situation för närstående är när deras make/maka, mor/far behöver flytta till ett annat boende för att få vård. I en intervjustudie från Norge beskriver bland annat barn till äldre föräldrar sin upplevelse av föräldrarnas flytt till ett äldreboende. Studien visar att närstående upplevde flytten som omvälvande för sin förälder men också för dem själva. Närstående kände sig ansvariga för den äldre personen även efter flytten och de försökte upprätthålla värdighet och kontinuitet för den äldre (Eika, Espnes, Söderhamn \& Hvalvik, 2014). Liknande resultat återfinns i en annan intervjustudie, även den från Norge. Studien visar att det som närstående upplevde som svårast var att ta beslut i den äldre personens ställe (Bollig, Gjengedal \& Rosland, 2015). En studie från Sverige visar att närstående upplevde att de inte hade något annat val än att besluta om en flytt och att fungera som advokat i den äldre personens ställe (Sandberg, Lundh \& Nolan, 2002). Ytterligare en intervjustudie från Sverige beskriver att samma situation medförde tankar av oro inför framti- 
den och känslor som skam och skuld. Före flytten upplevde närstående att deras egna behov stod tillbaka på grund av situationen som de levde i. Efter flytten upplevde närstående en fortsatt kamp och utmattning men också att det fanns en ny känsla av frihet som gav förnyad kraft (Hogsnes, Melin-Johansson, Norbergh \& Danielsson, 2014). En annan studie visar att närstående upplevde en förändring över tid i sin relation med den äldre när denna flyttat till ett äldreboende trots att de strävade efter att upprätthålla relationen och bevara den äldres identitet (Koplow et al., 2015). Utifrån ovanstående forskning är det rimligt att dra slutsatsen att många närstående som vårdar en person i sin närhet har en krävande situation såväl fysiskt, psykiskt, socialt som emotionellt.

Att vara närstående till en skör äldre person handlar också om att se sin partner, mor, far eller vän förändras i takt med försämrad hälsa och ett ökande behov av vård. En systematisk litteraturstudie av kvalitativa studier beskriver hur roller kan skifta från att vara till exempel dotter och mor, till att dottern blir förälder till sin mor (Funck et al., 2010). Studien visar att närstående önskade vara nära sin familjemedlem, särskilt när livet gick mot sitt slut trots upplevelser av ångest, rädsla, skuld, sorg och hjälplöshet (a.a.). I en intervjustudie med närstående framgår det att de såg sig som följeslagare till den äldre intill livets slut, de anpassade sin vardag efter den äldre personens behov, de tog huvudansvaret för hemmet och för övriga familjemedlemmar och de behövde få kraft genom stöd från andra (Andersson, Ekwall, Hallberg \& Edberg, 2010). Studier visar att närstående är i en sårbar situation när relationen med den partner som de levt med under lång tid gått förlorad genom död eller genom sjukdom såsom demenssjukdom (Førsund, Skovdahl, Kiik \& Ytrehus, 2015; Pozzebon, Douglas \& Ames, 2016).

Att vara närstående och förhålla sig till en vårdande roll kan också te sig olika för män och kvinnor. Studier som har antagit ett genusperspektiv i synen på äldre personer som vårdar sin make eller maka visar till exempel att äldre kvinnor som vårdar sina män ofta satte sina egna behov åt sidan och att de upplevde att det fanns en föreställning både hos dem själva och från samhället att de skulle vårda sina män (Eriksson, Sandberg \& Hellström, 2012). Andra studier har undersökt äldre mäns upplevelser av att vårda sin maka och fann att förändringen i rollerna var framträdande. Rollen förändrades från att vara make till att vara vårdare och att det var svårt att identifiera sig med en vårdande roll (Sandberg \& Eriksson, 2007; Greenwood \& Smith, 2015). I en kvantitativ studie av 171 äldre informella vårdares tillfredställelse av att vårda någon i sin närhet visar resultatet att männen överlag var 
mer nöjda än kvinnorna. För männen gav vårdandet mening och nya insikter medan kvinnorna, som ofta skött hem och hushåll tidigare, i högre grad skattade att vardagen fortsatte men med en ökad arbetsbörda (Kristensson Ekwall \& Rahm Hallberg, 2007).

\section{Behov av stöd och anhörigkonsulentens funktion}

För att kunna vara ett stöd är det troligt att närstående själva behöver stöd. I Sverige regleras stöd till närstående via ett tillägg som gjordes 2009 (2009:549) i Socialtjänstlagen $(2001: 453$, kap 5, §10) som handlar om att kommunerna ska erbjuda stöd till personer som vårdar eller stödjer någon som är långvarigt sjuk, äldre eller har funktionshinder. Tillägget kom till efter flera års strävande efter att förbättra situationen för informella vårdare (Johansson, Long \& Parker, 2011). Denna så kallade informella vård involverar ungefär var femte vuxen person i Sverige (Socialstyrelsen, 2012). Stödet till närstående kan vara indirekt, det vill säga riktat till personen i behov av vård såsom hälso- och sjukvård i det egna hemmet eller dagliga aktiviteter. Stödet kan också vara direkt, det vill säga stödjande insatser som är direkt riktade till närstående som ger informell vård. Exempel på stödinsatser är samtalsgrupper, studiecirklar och att till exempel ha avsedda fysiska mötesplatser för närstående. Varje kommun ansvarar själva för hur stödet organiseras och följs upp (Johansson, Long \& Parker, 2011; Winqvist, 2016:4). I de flesta kommuner finns en person utsedd som har hand om frågor som rör närstående. Denna roll benämns oftast som anhörigstödjare, anhörigstrateg, anhörigkonsulent eller anhörigsamordnare. I denna avhandling används benämningen anhörigkonsulent.

Två rapporter som berör anhörigkonsulentens funktion har getts ut av Nationellt kompetenscentrum anhöriga (Nka). Den ena är en enkätundersökning om anhörigkonsulentens arbete och yrkesroll (Winqvist, 2014:1). Rapporten visar att anhörigkonsulenterna ser sin roll som viktig i kommunens arbete med stöd till anhöriga och de upplever att de gör skillnad för anhörigas välmående. Den andra rapporten är en övergripande utvärdering av arbetet med stöd till anhöriga där åtta kommuner har utvärderats genom intervjuer och samtal med anhöriga, personal och chefer (Winqvist et al., 2016:2). Båda rapporterna visar att uppdraget som anhörigkonsulent och stödet som erbjuds ser olika ut och utförs på olika sätt, samt att uppbyggnaden av stödfunktioner varierar. Funktioner som har likheter med den svenska anhörigkonsulenten finns även i andra länder. Bland annat visar en intervjustudie från Kanada att anhörigkonsulenterna såg sig som en länk mellan familjen/närstående 
och hälso- och sjukvården, de samarbetade med flera andra professioner och deras fokus var familjen/närståendes behov (Goodridge, Isinger \& Rotter, 2018).

Forskning visar sedan ett tjugotal år tillbaka att det finns behov av ett direkt stöd som specifikt riktas till närstående, särskilt när livet går mot sitt slut. Ett sådant exempel är studien av Bolmsjö och Hermerén (2001) som belyser att närstående behövde stöd för att vara nära sin anhörige när livets sista tid närmade sig. Ett annat exempel är Andershed och Ternestedts (2001) forskning som utifrån fyra tidigare studier utvecklat ett teoretiskt ramverk som handlar om vad som främjar respektive hindrar närstående att vara delaktiga och involverade $\mathrm{i}$ vården som ges. Ramverket handlar om att, som närstående, befinna sig i ljuset eller i mörkret där vårdpersonal har en viktig uppgift $i$ att uppmärksamma närståendes behov. Att vara i ljuset innebar att närståendes behov av stöd och information var uppmärksammat och tillgodosett vilket gjorde att de upplevde sin situation som meningsfull och hanterbar. Att vara i mörkret innebar att närståendes behov av information och stöd inte blev uppmärksammat och tillgodosett vilket gjorde att de famlade i mörker. Eftersom de saknade information och kunskap kunde de inte vara det stöd som de skulle kunna varit om de hade haft information och kunskap (a.a.).

Andra exempel på forskning som visar behovet av stöd återfinns i en systematisk litteraturstudie som har fokus på närståendes situation och behov i palliativ vård. Resultatet beskriver att en aspekt av stöd är att få anpassad information och en annan aspekt är att det finns vårdpersonal som visar intresse och lyssnar (Andershed, 2006). Liknande resultat visar en intervjustudie med 20 informella vårdare till äldre personer (Stoltz, Willman \& Udén, 2006). Ett ytterligare exempel återfinns i en systematisk litteraturstudie som bygger på 16 empiriska studier. Resultatet visar att närstående till äldre personer som bodde hemma hade kontinuerliga behov som inte uppmärksammades och därför fallerade även stödet (Anker-Hansen, Skovdahl, McCormack \& Tønnessen, 2018). Andra studier efterlyser forskning om hur närstående kan göras delaktiga och på så sätt känna att de har stöd (Boise \& White, 2004; Irving, 2015; Wallerstedt et al., 2018; Ris, Schnepp \& Imhof, 2019).

Slutsatsen från en integrativ litteraturstudie baserad på 17 empiriska studier är att närstående som lever nära en person i livets slut behöver kontinuerligt existentiellt stöd. Situationen beskrivs som att leva i dödens närhet - en situation då närstående behövde bli sedda och mötta i sin ovisshet och ångest. Endast ett fåtal av de ingående studierna fokuserade på hur närståendes existentiella behov kunde mötas och hanteras (Melin-Johansson, Henoch, Strang \& Browall, 2012). En annan integrativ 
litteraturstudie visar att närstående som vårdar en skör äldre person hemma behövde emotionellt stöd från personal och att det finns ett behov av att utveckla strategier som en hjälp för närstående att hantera emotionell påfrestning (Silva, Teixeira, Teixeira \& Freitas, 2013). Liknande resultat visar en systematisk litteraturstudie från Sydkorea (Oh \& Han, 2019).

En systematisk litteraturstudie av 44 studier som handlar om informella vårdare som vårdar en skör äldre person hemma visar att det finns behov av att utveckla stödstrukturer som riktas till närstående. Det handlar om att ha struktur för att ge information och stöd (Plöthner, Schmidt, de Jong, Zeidler \& Damm, 2019). Forskning visar också behov av stöd som riktas specifikt till män (Greenwood \& Smith, 2015; Sandberg \& Eriksson, 2007) eller till kvinnor (Eriksson et al., 2012) som vårdar en skör äldre partner. Likaså finns det studier som belyser betydelsen av riktat stöd beroende på ålder, det vill säga om man är yngre eller äldre som vårdar och vilken betydelse det har för stödet som behövs (Greenwood \& Smith, 2016). Således visar studier inom området att stöd till närstående är angeläget och bör vara kontinuerligt. Anhörigkonsulentens uppdrag borde även omfatta existentiellt stöd men i dagsläget är det sparsamt beskrivet hur de ser på, vad de gör, samt vad de önskar göra för att ge stöd i existentiella frågor.

\section{Personcentrering}

För att bättre förstå, närma sig och förmedla stöd till sköra äldre personer och deras närstående är ett sätt att handla och tänka utifrån ett personcentrerat förhållningssätt. I mitt avhandlingsarbete har personcentrering varit vägledande i mötet med närstående, i forskningsetiska val som gjorts och i resultat som förmedlats. Värdegrunden för personcentrering, och således också i mitt avhandlingsarbete, har sin utgångspunkt $\mathrm{i}$ en humanistisk människosyn och handlar om respekt för varje person (alla människors lika värde), rätten till självbestämmande (alla människors rätt att bestämma över sitt eget liv), ömsesidig respekt och förståelse (alla människors rätt att bli sedda och mötta) (McCormack \& McCance, 2017).

Personcentrering är bland annat grundad i psykologen Carl Rogers (1961/2003) och Bubers (1923/2013) syn på mötet mellan människor. Ett möte som bör präglas av äkthet, acceptans och förståelse (Rogers, 1961/2003). En nutida beskrivning av personcentrering är ett förhållningssätt som har sin grund i att se varje person som en unik individ och att främja hälsosamma relationer mellan personer som befinner sig i ett sammanhang (McCormack \& McCance, 2017). Personcentrering beskriver 
en människas personliga sfär utifrån att den inrymmer: tillvaron, relationerna, omvärlden, platsen och tiden. Genom dessa fem delar blir vår person till (becoming), upprätthålls (being) och omformas (transform) (a.a.). Människan är alltså inte "bestämd" utan formas genom livet (Dahlberg \& Ekman, 2017).

Personcentrering syftar till att stärka en person att känna tillit till sina val, sin förmåga samt känsla av kontroll i sin situation, något som oftast benämns som empowerment (McCormack \& McCance, 2017). För att ett möte ska ge en sådan styrka, empowerment, behövs genuina möten där intresset för varandra är avgörande (Rogers, 1961/2003; Buber, 1923/2013). Ett sådant exempel är att involvera närstående och lyssna till dem genom hela vårdkedjan (Dahlberg \& Ekman, 2017; Søvde et al., 2019). Vårdens uppgift är att verka för hälsa och välbefinnande hos hela befolkningen (HSL, 2017:30). Att ha hälsa handlar, förutom att få fysiska, sociala och emotionella behov tillgodosedda, också om att bli sedd och mött i sina existentiella behov och i sin existentiella ensamhet. Att aktivt rikta tanken mot en helhetsbild, det vill säga att utgå från personens livsvärld (Dewing et al., 2017), innebär att även närståendes perspektiv uppmärksammas, tillvaratas och tillgodoses. För att nå en närmare förståelse för existentiell ensamhet är det av betydelse att undersöka olika aktörers upplevelser och uppfattningar, kontraster mellan dessa samt vilket existentiellt stöd som ges. 


\section{SYFTE}

Det övergripande syftet var att utforska existentiell ensamhet ur ett närståendeperspektiv, kontrastera detta mot äldre personers upplevelser samt beskriva närståendes och anhörigkonsulenters syn på existentiellt stöd.

De specifika syftena var:

- Att utforska existentiell ensamhet hos makar som vårdar, eller har vårdat, sin sköra partner sent $\mathrm{i}$ livet (I).

- Att utforska sköra äldre personers existentiella ensamhet, så som den tolkas av deras närstående (II).

- Att kontrastera sköra äldre personers upplevelse av existentiell ensamhet mot närståendes uppfattningar (III).

- Att undersöka anhörigkonsulenters syn på existentiell ensamhet och existentiellt stöd till närstående till äldre personer (IV).

- Att beskriva närståendes syn på existentiellt stöd (ramberättelse). 


\section{METOD}

\section{Design}

Avhandlingen är en del av ett större forskningsprojekt, LONE-studien, RR210.2196/1307 (Edberg \& Bolmsjö, 2019). LONE-studien är i utvecklingsfasen av en komplex intervention i linje med Medical Research Councils ramverk (MRC, 2008). Forskningsprojektets övergripande syfte var att undersöka existentiell ensamhet utifrån tre olika perspektiv; sköra äldre personer, deras närstående samt vård- och omsorgspersonal. Denna avhandling har antagit ett närståendeperspektiv.

Avhandlingen består av fyra delarbeten, tre är kvalitativa studier (I, II, III) och en är kvantitativ (IV). Därtill har nya resultat lyfts in i ramberättelsen. För en översikt av studierna se tabell 1. Eftersom existentiell ensamhet var sparsamt utforskat var kunskapen begränsad. Därför var det viktigt att vara öppen för det som studierna visade. De kvalitativa studierna antog därför en explorativ design som innebär att ha ett öppet och utforskande förhållningssätt till det som undersöks (Polit \& Beck, 2017). I kvantitativa studier är designen många gånger förutbestämd som i studie IV där en tvärsnittsstudie valdes med en undersökning vid en given tidpunkt $i$ en förutbestämd population (a.a.). Studie I, II och III gjorde det möjligt att utforska existentiell ensamhet ur ett närståendeperspektiv på djupet genom intervjuer och textanalyser medan studie IV gjorde det möjligt att undersöka bredd avseende existentiell ensamhet och existentiellt stöd via en enkät och statistisk analys.

Ungefär en miljon personer av Sveriges befolkning är över 75 år (SCB, 2018). Den formella vården av äldre personer ges till största del av anställda i de 290 kommunerna. Den informella vården ges av släktingar, partner och vänner och är den vård, det stöd och den hjälp som ges utan ekonomisk ersättning. I studie I kom informanterna från två olika kommuner i södra Sverige. Studie II och III genomfördes inom olika vårdkontexter såsom hemtjänst/hemsjukvård, särskilt boende, primärvård, spe- 
cialiserad palliativ vård och sjukhus i södra Sverige. I studie IV skickades enkäten ut till samtliga identifierade anhörigkonsulenter med en anställning inriktad på att erbjuda stöd till närstående till äldre personer i Sveriges 290 kommuner.

Tabell 1. Översikt av studierna: syfte, deltagare, datakälla och dataanalys.

\begin{tabular}{|c|c|c|c|c|}
\hline Studie & Syftet var att: & Deltagare & Datakälla & Dataanalys \\
\hline $\mathbf{I}$ & $\begin{array}{l}\text { utforska existentiell } \\
\text { ensamhet hos makar som } \\
\text { vårdar eller har vårdat sin } \\
\text { sköra partner sent i livet }\end{array}$ & $10 \mathrm{Make} / \mathrm{maka}$ & $\begin{array}{l}\text { Fokusgrupps- } \\
\text { intervjuer } \\
\text { i flera steg }\end{array}$ & $\begin{array}{l}\text { Hermeneutisk } \\
\text { analys med } \\
\text { poem }\end{array}$ \\
\hline II & $\begin{array}{l}\text { utforska sköra äldre per- } \\
\text { soners existentiella en- } \\
\text { samhet, så som den tolkas } \\
\text { av deras närstående }\end{array}$ & 19 Närstående & $\begin{array}{l}\text { Individuella } \\
\text { intervjuer }\end{array}$ & $\begin{array}{l}\text { Innehålls- } \\
\text { analys }\end{array}$ \\
\hline III & $\begin{array}{l}\text { kontrastera sköra äldre } \\
\text { personers upplevelse av } \\
\text { existentiell ensamhet mot } \\
\text { närståendes uppfattningar }\end{array}$ & $\begin{array}{l}19 \text { Närstående } \\
15 \text { Äldre } \\
\text { personer* } \\
\text { Fält- } \\
\text { anteckningar* }\end{array}$ & $\begin{array}{l}\text { Individuella } \\
\text { intervjuer } \\
\text { (samma som i } \\
\text { studie II) }\end{array}$ & $\begin{array}{l}\text { Fallstudie } \\
\text { med tematisk } \\
\text { analys }\end{array}$ \\
\hline IV & $\begin{array}{l}\text { undersöka anhörigkonsul- } \\
\text { enters syn på existentiell } \\
\text { ensamhet och existentiellt } \\
\text { stöd till närstående till } \\
\text { äldre personer }\end{array}$ & $\begin{array}{l}120 \text { Anhörig- } \\
\text { konsulenter }\end{array}$ & Enkät & $\begin{array}{l}\text { Beskrivande } \\
\text { statistisk } \\
\text { analys }\end{array}$ \\
\hline $\begin{array}{l}\text { Ram- } \\
\text { berättelse }\end{array}$ & $\begin{array}{l}\text { beskriva närståendes syn } \\
\text { på existentiellt stöd }\end{array}$ & $10 \mathrm{Make} / \mathrm{maka}$ & $\begin{array}{l}\text { Fokusgrupps- } \\
\text { intervjuer } \\
\text { i flera steg } \\
\text { (samma som i } \\
\text { studie I) }\end{array}$ & $\begin{array}{l}\text { Innehålls- } \\
\text { analys }\end{array}$ \\
\hline
\end{tabular}

*intervjuer med äldre personer samt fältanteckningar genomfördes av Marina Sjöberg (MS), doktorand och Ingela Beck (IB), senior forskare, inom ramen för LONE-studien.

\section{Studiedeltagare och procedur}

Totalt har 164 personer deltagit i studierna varav 29 närstående, 15 sköra äldre personer och 120 anhörigkonsulenter. När det gäller närstående och sköra äldre personer har variation avseende ålder, kön och vårdkontext i urvalet eftersträvats. Att sträva efter variation var viktigt för att få olika erfarenheter och på så sätt fånga flera karakteristika (Polit \& Beck, 2017) samt fler upplevelser och uppfattningar om existentiell ensamhet. Gällande anhörigkonsulenter har en totalundersökning (a.a.) gjorts som innebär att samtliga identifierade elektroniska postadresser till anhörigkonsulenter vilkas tjänster, helt eller delvis, var utformade för att ge stöd till närstående till äldre personer har fått en enkät. Proceduren att nå presumtiva deltagare har präglats av ett nära samarbete med företrädare för olika vårdkontexter. 
Deltagarna i studie I och i ramberättelsen bestod av tio makar varav fem var män och fem var kvinnor. De var mellan 67 och 89 år gamla, med en median på 79,5 år. De hade levt tillsammans med sin partner mellan 46 och 65 år, med en median på 51,5 år. Inklusionskriterier var att ha erfarenhet av att leva tillsammans med och vårda sin sköra äldre partner, att se sig som ett par under lång tid samt att se sig som huvudansvarig för sin partner. För att få variation i upplevelser var strävan att nå både män och kvinnor, de som levde tillsammans och de som hade blivit änka/änkling. Deltagarna delades in i två grupper. Den första gruppen bestod av fem make/maka som levde tillsammans, medan den andra gruppen bestod av fem make/maka vars partner hade dött. De hade förlorat sin partner för mellan ett och fyra år sedan, med en median av två år. För beskrivning av partnerns huvudsakliga sjukdom, boende och vårdform se tabell 2.

Tabell 2. Beskrivning av partnerns huvudsakliga sjukdom, boende, vårdform (I)

\begin{tabular}{cl}
\hline Make/maka & $\mathrm{n}=10$ \\
\hline Partnerns huvudsakliga sjukdom & 6 \\
Demens & 3 \\
Cancer & 1 \\
Annan & 5 \\
Partnerns boende och vårdform* & 5 \\
Bor/bodde i ordinärt boende & 3 \\
Särskilt boende & 3 \\
Hemsjukvård & 3 \\
Hemtjänst & 47 år (5-86 år) \\
Palliativ vård & Alla svarade ja \\
Bott i samma kommun, median (variationsvidd) & 5 \\
Om något händer, har du någon att kontakta? & 1 \\
Har du någon som kan avlasta dig? & 4 \\
Ja &
\end{tabular}

*Flera alternativ möjliga

En anhörigkonsulent i två olika kommuner i södra Sverige kontaktades och informerades om studien genom ett fysiskt möte med mig. Konsulenten agerade därefter som en länk mellan mig och presumtiva deltagare, till exempel genom att tillfråga makar om det var möjligt att lämna deras namn och telefonnummer till mig. Anhörigkonsulenten gav även ett informationsbrev till intresserade makar. Brevet innehöll information om syftet med studien, en beskrivning av existentiell ensamhet som en djupare känsla av ensamhet och en garanti om konfidentialitet. Målet var att varje grupp skulle bestå av fyra till sex deltagare (Krueger \& Casey, 2015). Det var viktigt 
att gruppen blev lagom stor, dels för att alla skulle få möjlighet att komma till tals och dels för att, med tanke på ämnets karaktär, få en trygg atmosfär och möjlighet till givande samtal i gruppen. Totalt kommunicerades 15 namn och telefonnummer varav tio makar tackade ja till att delta i studien. De som tackade nej gjorde det på grund av hälsoskäl, en önskan om att slippa tala om ett sådant ämne eller genom att inte svara i telefonen trots upprepade försök. Det kommunicerades inte vidare till anhörigkonsulenten vilka makar som hade tackat ja respektive nej.

Deltagarna i studie II var närstående till sköra äldre personer. De närstående var sex män och 13 kvinnor mellan 49 och 86 år, med en median av 63 år. Inklusionskriterier var att inte ha kognitiv nedsättning samt bedömas orka med en intervju. För beskrivning av närståendes relation till den sköra äldre personen, se tabell 3.

Tabell 3. Beskrivning av närståendes relation till den sköra äldre personen (II, III)

\begin{tabular}{ll}
\hline Närstående & $\mathrm{n}=19$ \\
\hline Söner/döttrar & $5 / 4$ \\
Syskon & 1 \\
Vän & 1 \\
Svärdotter & 1 \\
Hustrur & 4 \\
Avlägsen släkting & 1 \\
Syskonbarn & 2 \\
\hline
\end{tabular}

De närstående identifierades via intervjuer med äldre personer. En annan doktorand och en forskare (MS och IB) inom ramen för LONE-studien genomförde intervjuerna med de äldre personerna. Även om strävan var att nå variation i närståendes uppfattningar om existentiell ensamhet fanns det ingen möjlighet att påverka urvalet eftersom närstående identifierades via den äldre personen. Efter intervjun med de äldre ställdes frågan om de hade någon i sin närhet som vi fick tillåtelse att tillfråga om en intervju. Om den äldre uppgav ett eller flera namn förmedlades detta/dessa vidare tillsammans med telefonnummer till mig. Totalt uppgavs 20 närstående varav en avböjde att delta. Någon vecka efter intervjun med den äldre personen kontaktades närstående via telefon. Vid telefonsamtalet beskrevs studien i korthet med förfrågan om att få skicka ett informationsbrev. Brevet innehöll information om syftet med studien, en beskrivning av existentiell ensamhet som en djupare känsla av ensamhet samt uppgifter om forskningsetiska aspekter som rätten att avsluta sitt deltagande och konfidentialitet. Några dagar efter att informationsbrevet skickats ut kontaktades 
närstående på nytt via telefon med förfrågan om att delta i studien. Om närstående ville delta avtalades en tid och plats för intervjun.

Deltagarna i studie III var sköra äldre personer, samt deras närstående som också ingick i studie II (se beskrivning ovan). Inklusionskriterier avseende de äldre personerna var att vara över 75 år, inte ha kognitiv nedsättning, vara i behov av varaktig vård och omsorg samt bedömas orka med en intervju. Totalt ingick 23 äldre personer men endast 16 av dem hade uppgett namn på en eller två närstående. En närstående avböjde att delta vilket resulterade i att det fanns närstående till 15 av de äldre personerna. Eftersom intervjuerna med äldre personer skulle paras samman med intervjuerna med närstående, var det endast möjligt att använda dessa 15 intervjuer med äldre personer. De äldre som således fanns med i urvalet var åtta kvinnor och sju män i en ålder mellan 76 år och 101 år, med en median av 86 år. Fyra av dem bodde på ett särskilt boende och 11 av dem i ordinärt boende. För beskrivning av deras vårdkontexter se tabell 4 .

Tabell 4. Beskrivning av sköra äldre personers vårdkontext (III)

\begin{tabular}{ll}
\hline Äldre personer & $\mathrm{n}=15$ \\
\hline Vårdkontext & \\
Primärvård & 4 \\
Hemsjukvård & 2 \\
Särskilt boende & 4 \\
Sjukhusvård & 1 \\
Palliativ vårdavdelning & 1 \\
Palliativ vård i hemmet & 3 \\
\hline
\end{tabular}

De äldre personerna identifierades via vårdenhetens kontaktperson, som tillfrågade de äldre om det var möjligt att lämna vidare deras namn samt gav dem ett informationsbrev. Brevet innehöll information om syftet med studien, en beskrivning av existentiell ensamhet som en djupare känsla av ensamhet samt uppgifter om forskningsetiska aspekter som rätten att avsluta sitt deltagande och konfidentialitet. Om den äldre gav sin tillåtelse förmedlades namnet vidare till MS och IB. De äldre kontaktades därefter med en förfrågan om att delta i studien. Om den äldre ville delta avtalades dag, tid och plats för intervjun.

Deltagarna i studie IV var anhörigkonsulenter i Sveriges 290 kommuner. Konsulenternas uppdrag var att stödja närstående till äldre personer. En enkät som var utvecklad specifikt för denna studie skickades ut via elektronisk post. Totalt identifierades 349 adresser till anhörigkonsulenter via kommunernas hemsidor. Åtta enkäter nådde 
ingen fungerande adress, sju enkäter exkluderades eftersom respondenterna angett att deras tjänst inte var riktad till närstående till äldre personer. Den totala svarsfrekvensen var $\mathrm{n}=120$ (36\%). Respondenterna var fem män och 115 kvinnor, i åldern 34-66 år (median 55 år). De hade arbetat som anhörigkonsulenter mellan tre månader och 27 år, med en median på sju år. Övervägande del av dem arbetade ensamma i sin roll som anhörigkonsulenter. De hade varierande utbildningar för sitt uppdrag; sjuksköterska (13\%), socionom (9\%), arbetsterapeut (7\%), beteendevetare (8\%) och andra utbildningar (63\%). Andra utbildningar eller kurser som de angav var; gerontologi (43\%), kommunikation och stöd (34\%), ledarskap (9\%), psykologi och socialpsykologi (9\%) samt filosofi och själavård (5\%). För beskrivning av anhörigkonsulenterna som besvarat enkäten se tabell 5 .

Tabell 5. Beskrivning av anhörigkonsulenterna som besvarat enkäten (IV)

\begin{tabular}{|c|c|c|}
\hline Respondenter & $\mathrm{n}=120$ & $\%$ \\
\hline \multicolumn{3}{|l|}{ Den nivå som du är verksam på är: } \\
\hline Både operativ och strategisk & 65 & 54 \\
\hline Endast operativ & 44 & 37 \\
\hline Endast strategisk & 7 & 6 \\
\hline Inget svar & 4 & 3 \\
\hline \multicolumn{3}{|l|}{ Antal invånare i kommunen där du tjänstgör: } \\
\hline Färre än 50000 & 82 & 68 \\
\hline $50000-300000$ & 30 & 25 \\
\hline $300000-500000$ & 1 & 1 \\
\hline Fler än 500000 & 3 & 3 \\
\hline Vet inte & 2 & 2 \\
\hline Inget svar & 2 & 2 \\
\hline \multicolumn{3}{|l|}{ Din tjänst är riktad till anhöriga till äldre personer: } \\
\hline Delvis & 73 & 61 \\
\hline $\mathrm{Ja}$ & 47 & 39 \\
\hline \multicolumn{3}{|l|}{ Det finns en arbetsbeskrivning för din tjänst: } \\
\hline $\mathrm{Ja}$ & 55 & 46 \\
\hline Nej & 33 & 28 \\
\hline Delvis & 30 & 25 \\
\hline Inget svar & 2 & 2 \\
\hline \multicolumn{3}{|l|}{ Din arbetstitel är: } \\
\hline Konsulent & 51 & 43 \\
\hline Samordnare & 46 & 38 \\
\hline Stödjare & 15 & 13 \\
\hline Chef & 4 & 3 \\
\hline Demenssjuksköterska & 2 & 2 \\
\hline Inget svar & 2 & 2 \\
\hline
\end{tabular}




\section{Datainsamlingsmetoder}

I avhandlingen har olika datakällor använts. Fokusgruppsintervjuer i flera steg användes för att undersöka närståendes upplevelser (I, ramberättelse) och individuella intervjuer användes för att belysa närståendes uppfattningar (II) och för att kontrastera dessa mot äldre personers upplevelser (III). Slutligen användes en enkät för att undersöka anhörigkonsulenters syn på existentiell ensamhet och existentiellt stöd (IV).

Samtliga intervjuer, både fokusgrupper och individuella, inleddes med att muntligt upprepa informationen som de hade fått skriftligt $\mathrm{i}$ brevet. I brevet introducerades existentiell ensamhet enligt följande:

...Många människor har ett behov av att prata med andra om existentiella frågor och de tankar man har kring sitt eget liv och sin egen död. Existentiell ensamhet, det vill säga en djupare känsla av ensamhet, som att stå ensam och utlämnad åt sig själv, verkar uppträda när hotande händelser såsom förluster av olika slag drabbar oss...

Därefter ställdes en övergripande fråga om ensamhet generellt och sedan om existentiell ensamhet specifikt. Frågan rörande existentiell ensamhet introducerades så här:

...Ensam kan man vara på många olika sätt. Man kan känna sig ensam tillsammans med andra. Man kan vilja vara ensam och kanske till och med längta efter att vara ensam. I vårt forskningsprojekt är vi särskilt intresserade av en djupare känsla av att vara ensam i livet det som ibland kallas existentiell ensamhet, en känsla som kan komma och gå...

\section{Intervjuer}

\section{Fokusgruppsintervjuer}

För studie I och analysen i ramberättelsen samlades data in via fokusgruppsintervjuer i flera steg (Hummelvoll, 2008). Eftersom studie I har en hermeneutisk ansats var det av betydelse att nå ett djup i intervjuerna. Hummelvoll (2008) beskriver fokusgruppsintervjuer i flera steg som en datainsamlingsmetod som möjliggör att fånga ett djup eftersom en och samma grupp träffas vid upprepade tillfällen. Dels gör de upprepade tillfällena att informanterna kan känna trygghet och därför berätta om sina upplevelser, dels möjliggör det för forskaren/na att återkomma med frågor som uppkommer efter intervjun (a.a.). 
Två grupper med fem deltagare i varje grupp träffades vid tre tillfällen vardera. Varje fokusgruppsintervju varade i två timmar och genomfördes mellan augusti och oktober 2018. Mellan fokusgruppsintervju ett och två gick det två veckor, och mellan intervju två och tre gick det tre veckor. Tiden mellan sammankomsterna var betydelsefull för att kunna sammanställa vad som sagts under intervjun och baserat på sammanställningen kunna planera för vad som kunde fördjupas under nästkommande intervju. Varje fokusgruppsintervju spelades in för att därefter transkriberas. Transkriberingen genomfördes av en person utanför forskargruppen med vana av transkribering. Samtliga fokusgruppsintervjuer genomfördes i en lokal som tillhandahölls av kommunen. Tidpunkt för intervjuerna beslutades i samråd med deltagarna. Båda fokusgrupperna hölls intakta genom samtliga tre sammankomster och alla deltagarna, med ett undantag för en person i respektive grupp, deltog vid samtliga fokusgruppsintervjuer.

Under fokusgruppsintervjun hade jag rollen som moderator med en senior forskare i rollen som observatör. Moderatorns roll är att leda intervjun medan observatörens roll är att observera vad som sker i samtalet och föra anteckningar (Polit \& Beck, 2017). Varje sammankomst med fokusgruppen inleddes med en kort sammanfattning av studiens syfte. Enligt Hummelvoll (2008) bör det första tillfället ägnas åt att skapa en god atmosfär i gruppen. Detta gjordes genom att alla i gruppen presenterade sig för varandra och berättade om sin situation som närstående till en skör äldre partner. Därefter inleddes fokusgruppen med att samtala om ensamhet generellt för att därefter introducera och fokusera på existentiell ensamhet. Frågor som deltagarna fick reflektera över var: Hur upplever du ensamhet i din situation just nu? I relation till det, vad skulle du kunna berätta om existentiell ensamhet? I den grupp vars deltagare hade förlorat sin make/maka, ombads deltagarna att berätta om hur de upplevde existentiell ensamhet när deras partner levde i relation till hur det var nu. I båda grupperna uppmuntrades deltagarna att berätta om sina upplevelser och att reflektera över både sina egna och varandras berättelser. Några dagar efter varje fokusgruppsintervju träffades jag och den seniora forskaren för att lyssna igenom intervjun, diskutera vad som hade berättats om existentiell ensamhet och sammanställa det som bedömdes som viktigt att fördjupa vid nästkommande fokusgruppsintervju.

\section{Individuella intervjuer}

För studie II samlades data in via 18 intervjuer med totalt 19 närstående. Två pilotintervjuer gjordes för att testa intervjuguiden och några mindre justeringar gjordes. Intervjuerna var individuella med undantag för en intervju som var med ett par. Intervju- 
erna varade mellan 40 och 90 minuter (median 51 minuter) och genomfördes mellan februari 2015 och augusti 2016. Med tanke på ämnets karaktär och för att säkerställa att så mycket som möjligt fångades upp under intervjun (Thomson, 2010) gjordes samtliga intervjuer av mig och, med något undantag, medverkade även en senior forskare. Samtliga närstående karakteriserade sin relation till den äldre personen som nära eller mycket nära. De närstående såg sig i första hand som närstående till den äldre personen snarare än deras informella vårdare. Intervjuerna utformades som ett samtal där vi efterfrågade berättelser. En intervjuguide användes med två övergripande öppna frågor och därefter uppföljande frågor (Polit \& Beck, 2017). Intervjun inleddes med att muntligt upprepa informationen som deltagarna hade fått skriftligt i brevet. Därefter fick närstående den första övergripande frågan som handlade om hur de uppfattade den äldres situation rent allmänt och därefter fortsatte intervjun med att samtala om ensamhet generellt och sedan om existentiell ensamhet specifikt. Frågan rörande existentiell ensamhet introducerades med ett tillägg som gjordes så här:

...Vi har intervjuat ett antal äldre personer om en djupare känsla av att vara ensam i livet. Vi är nu intresserade av närståendes perspektiv. Kan du dra dig till minnes ett tillfälle då din ... gett uttryck för en känsla av en djupare ensamhet?

När något kom upp som bedömdes som viktigt i relation till existentiell ensamhet ställdes fördjupande frågor såsom: Hur märkte du det? Hur var det? Kommer du ihåg vad du tänkte? Vad var det som gjorde det? Vid intervjutillfället tillfrågades närstående även om demografiska uppgifter såsom ålder, relation och hur ofta de hade kontakt. Intervjuerna spelades in digitalt och transkriberades av en person utanför forskargruppen som var förtrogen med transkribering av intervjuer.

Som datakälla i studie III användes dels intervjuerna med närstående, som beskrivits ovan, dels individuella intervjuer med sköra äldre personer som hade gjorts av en annan doktorand och en forskare inom LONE-studien. Intervjuerna med de äldre personerna varade mellan 46 och 147 minuter (median 72 minuter) och genomfördes mellan februari 2015 och juli 2016. Intervjun inleddes med att muntligt upprepa informationen som de hade fått skriftligt i brevet. Intervjuerna med de äldre personerna var i likhet med intervjuerna med närstående, av berättande karaktär och efter ett inledande samtal om vilka intervjuarna var och varför de var där påbörjades intervjun med att samtala om ensamhet generellt. Därefter introducerades frågan om existentiell ensamhet, på samma sätt som i fokusgruppsintervjuer och i intervjuer med närstående. Fördjupande frågor ställdes när något framkom som bedömdes viktigt $\mathrm{i}$ relation till existentiell ensamhet såsom: Hur var det? Skulle du kunna berätta lite 
mer? Eftersom de äldre personerna var sköra var det viktigt att vara lyhörda för när de inte längre orkade samtala. Vid intervjutillfället tillfrågades de även om demografiska uppgifter såsom ålder och om de bodde ensamma eller tillsammans med någon. Intervjuerna spelades in digitalt och transkriberades av en person utanför forskargruppen som var förtrogen med transkribering av intervjuer.

\section{Fältanteckningar}

Fältanteckningar skrevs i samband med intervjuerna med de äldre personerna och inkluderades som en datakälla i studie III. Eftersom jag själv inte deltagit i dessa intervjuer var anteckningarna viktiga för att förstå intervjusituationen. Eftersom en fallstudie intresserar sig för hur ett fenomen blir synligt i sitt sammanhang (Yin, 2009) blev fältanteckningarna viktiga för att förstå den kontext som den äldre personen befann sig i. Anteckningarna handlade om framför allt tre aspekter: 1) Den äldre personens fysiska miljö, som till exempel att de bodde i ett äldre hus med högt i tak nära centrum, i ett mindre hus på landet eller vid ett äldreboende med materiella ägodelar som påminde om hur livet varit tidigare; 2) Atmosfären vid intervjun, till exempel hur situationen var arrangerad och hur intervjupersonen mådde, som att fikabordet var dukat när intervjuarna kom, att de drack kaffe tillsammans eller om den äldre personen knappt orkade samtala; 3) Tankar och intryck av intervjusituationen, om den äldre personen hade svårt att göra sin röst hörd eller att finna ord för att beskriva sina upplevelser.

\section{Enkätundersökning}

Som datakälla i studie IV användes en enkät. Enkäten togs fram enbart för denna studie utifrån kunskap från tidigare forskningsresultat i LONE-studien (Edberg \& Bolmsjö, 2019) och från tillgänglig information från Nka (Winqvist, 2014:1; Winqvist et al., 2016:2; Winqvist, 2016:4). Enkäten distribuerades i februari 2019 och stängdes efter sju veckor. Två påminnelser skickades ut till dem som inte hade besvarat enkäten. Den andra påminnelsen distribuerades på en annan veckodag och vid en annan tid än den första påminnelsen för att se om det kunde ge fler svar.

Strävan var att skapa en enkät med tydlig struktur (Wenemark, 2017) och därför delades enkäten in i fem delar. Den första delen innehöll demografiska frågor såsom anhörigkonsulenternas ålder, kön, antal år i tjänsten, antal invånare i kommunen och så vidare. För beskrivning av respondenterna se tabell 5. Den andra delen i enkäten innehöll påståenden om existentiell ensamhet och den tredje delen bestod av påståenden om vilka personer som anhörigkonsulenten gav stöd. Den fjärde delen inne- 
höll påstående om vad anhörigkonsulenten gjorde för att ge existentiellt stöd och den femte, och därmed sista delen, bestod av påståenden rörande vilka förutsättningar anhörigkonsulenterna hade i sitt arbete för att ge existentiellt stöd. Anhörigkonsulenterna ombads att svara på ett påstående genom att gradera sin uppfattning på en flergradig Likertskala (Streiner \& Norman, 2008) från instämmer inte alls (1) till instämmer helt (4). I anslutning till varje del av enkäten fanns möjligheten att fritt skriva andra aspekter som respondenterna ville föra fram. För frågor och påstående i enkäten se Appendix I. I samma utskick som enkäten fanns ett informationsbrev bifogat. Brevet innehöll information om pågående projekt inom LONE-studien (Edberg \& Bolmsjö, 2019) samt etiska aspekter såsom att deras svar inte gick att spåra.

Innan enkät och informationsbrev distribuerades till samtliga anhörigkonsulenter var det viktigt att pilottesta utskicket i sin helhet (Wenemark, 2017). Testet gjordes med inspiration från "Think-aloud-method" ("tänka högt-metod") (Polit \& Beck, 2017). En anhörigkonsulent tillfrågades, utskicket distribuerades till konsulenten samtidigt som jag var närvarande. Anhörigkonsulenten läste informationsbrevet högt, delgav sina reflektioner och öppnade därefter enkäten, fortsatte att läsa högt och graderade sina påståenden. Att anhörigkonsulenten läste materielat högt var viktigt för att få en förståelse för om språket vid något tillfälle var svårt att förstå och att lyssna till reflektionerna över frågor och påståenden. Enkäten diskuterades även i forskargruppen och några mindre justeringar och förtydliganden gjordes. Enkäten skickades därefter ut via ett elektroniskt system som tillhandahölls av Högskolan Kristianstad.

\section{Analysmetoder}

I avhandlingen har olika analysmetoder använts. Att använda olika analysmetoder gör det möjligt att utforska data på flera sätt (Polit \& Beck, 2017). Tre olika metoder användes för att analysera intervjudata; hermeneutisk analys (Gadamer, 1960/1990), innehållsanalys (Hsieh \& Shannon, 2005) samt en fallstudie (Yin, 2009) med tematisk analys (Braun \& Clarke, 2006). Beskrivande statistisk analys användes för att analysera enkätundersökningen (Polit \& Beck, 2017).

\section{Hermeneutisk analys}

I studie I användes hermeneutisk analys eftersom strävan var att utforska existentiell ensamhet när man lever i en relation och att nå ett djup i tolkningen av intervjuerna. Hermeneutik intresserar sig för tolkning av mänskliga erfarenheter och syftar till att förstå och förklara (Gadamer, 1960/1990). Tolkningen ses som en cirkulär process som går fram och tillbaka mellan delar och helhet. Mötet med den transkriberade in- 
tervjutexten syftar till att nå ett samförstånd, en horisontsammansmältning, mellan vad texten vill säga och hur texten tolkas. Tolkningen präglas av tolkarens förförståelse och att medvetandegöra förförståelsen är därför avgörande för att förstå tolkningen i sitt sammanhang (a.a.).

Analysarbetet inleddes med att läsa samtliga transkriberade fokusgruppsintervjuer för att få en preliminär förståelse för texten som helhet. Under läsningen framkom tentativa teman som handlade om att vara i en process av förändring, att bli lämnad kvar, att ifrågasätta sig själv och andra samt saknaden av att, som tidigare, leva i en tvåsamhet. De tentativa temana diskuterades tillsammans med samtliga forskare i studien. När teman var klargjorda började meningsenheter från materialet identifieras och lyftas ut. Meningsenheterna som extraherades var snarare hela berättelser än korta enskilda meningar (Dahlberg, Dahlberg \& Nyström, 2008). För att ha en dialog med texten (Gadamer, 1960/1990) anammades Schusters (2006) och Edvardsson, Sandman och Rasmussens (2006) sätt att bearbeta text. Sättet att arbeta handlar om att bearbeta text språkligt genom att omarbeta text till poem (Gee, 1985; Gee, 1991).

Poemen konstruerades genom att använda en central berättelse, dela upp berättelsen genom att göra radbrytning vid en paus, dela in texten i mindre stycken, fundera på meningen bakom varje ord och rad, ta bort falska starter och tvekanden. Allt för att essensen i texten ska tydliggöras (Gee, 1985; Gee, 1991; Schuster, 2006). Att bearbeta texten med hjälp av poem främjar tolkningen eftersom ett poem oftast läses saktare och med en annan känsla. Till exempel finns det belägg för att andningen blir lugnare när man läser poesi (Rämgård, Nieminen Kristoffersson, 2010). Syftet med att använda denna särskilda teknik var också att synliggöra sådant som kan vara svårt att beskriva och på så sätt ge läsaren en känsla för vad existentiell ensamhet är. När poem hade valts ut och bearbetats för respektive tema påbörjades framskrivningen av analysen med målet att få läsaren att förstå hur analysen hade vuxit fram (Schuster, 2006). Slutligen gjordes en övergripande tolkning för att skapa en förståelse för helheten (Gadamer, 1960/1990; Dahlberg et al., 2008). Nedan följer ett exempel på hur text bearbetades: 
Det kommer inte frivilligt där får man tänka sig för jag vill också gärna säga vi och tänkandet

Tänka

jag

istället för $v i$

ja

och alltid detta med $v i$ längst inne i huvudet
Alltså påtvingat

Alltså behövs en medveten, riktad tanke

Texten talar om att en förändring tar tid och att den inte kommer frivilligt när man har levt tillsammans under lång tid. Två kvinnor som förlorat sina makar pratar om att förändras från att leva i ett $v i$ till att vara bara jag.

\section{Innehållsanalys}

Studie II och nya resultat i ramberättelsen analyserades med innehållsanalys enligt Hsieh och Shannon (2005) som beskriver tre olika sätt att förhålla sig till innehållsanalys; konventionell (induktiv ansats), summerande (räkna vissa ord/begrepp) och riktad (teoriknuten, deduktiv ansats). I studie II och i ramberättelse har konventionell innehållsanalys använts, den analysmetod som används för att beskriva ett fenomen som det finns begränsad kunskap om. Analysförfarandet karakteriseras av att hålla sig nära texten och att knyta an till teori i diskussionsavsnittet (a.a.).

Analysen i studie II inleddes med att de transkriberade individuella intervjuerna lästes i sin helhet. Syftet var att få en känsla av vad texten ville säga och när något verkade framträda som bedömdes handla om existentiell ensamhet gjordes en markering i kanten. Noteringarna ledde vidare till två frågor; "Vilka situationer gör att existentiell ensamhet väcks?" och "Hur uttrycks existentiell ensamhet?". Andra steget i analysen handlade om att gå igenom texten på nytt, i sin helhet, utifrån de två frågeställningarna. Meningsbärande enheter från texten identifierades. I det tredje steget kondenserades varje meningsbärande enhet och gavs en kod som fortfarande var textnära. I det fjärde steget tog tolkning vid och koderna gavs en djupare innebörd. I det femte och därmed sista steget, sammanfördes tolkningarna till kluster beroende på hur de kunde tolkas höra samman med varandra. Detta steg mynnade ut i tre kategorier som svarar på frågan "Enligt närstående, vilka omständigheter verkar göra att existentiell ensamhet väcks hos sköra äldre personer?”. 
Avseende resultat om närståendes syn på stöd som presenteras i ramberättelsen inleddes analysen med att samtliga fokusgruppsintervjuer lästes igenom i sin helhet. All text som handlade om sådant som de närstående beskrev som hjälp och stöd i deras situation markerades. Dessa markeringar lyftes därefter över i ett eget dokument och granskades utifrån vad texten talade om. Två riktningar fanns - dels talade närstående om stöd som de ger sig själva såsom att hålla sig aktiva och att ge sig själva tid, dels talade de om behovet av stöd från andra såsom att bli inbjuden till en formell samtalsgrupp. Texterna fördes samman med varandra beroende på hur de hörde ihop (klustrades) och när det arbetet bedömdes färdigt skrevs en text som presenteras i ramberättelsens resultat.

\section{Fallstudie med tematisk analys}

Studie III genomfördes som en "case study" (Yin, 2009) som i det svenska språket kan översättas till fallstudie (Jakobsson, 2011). En fallstudie gjordes eftersom strävan var att beskriva både hur existentiell ensamhet upplevdes av de äldre och uppfattades av deras närstående, kontrasterna där emellan och att se på dessa kontraster i sitt sammanhang. En fallstudie intresserar sig för och söker efter att förstå och förklara likheter såväl som skillnader av hur ett fenomen eller ett beteende framträder i sitt specifika sammanhang. Denna typ av studie söker djup och är lämplig att använda för fenomen och beteenden som inte är väl beforskade (Yin, 2009). Inom fallstudieområdet används flera olika begrepp. Studien kan vara utforskande, förklarande och beskrivande samt delas in i "singel" (en) eller "multipel" (flera). En fallstudie bör vara inbäddad (embedded) i sitt sammanhang och sträva efter att ge en helhetsbild (holistic) (a.a.). I studie III har en "singel" fallstudie använts eftersom de äldre personerna inte delades in utifrån till exempel vårdkontext eller relation till närstående. Om så hade gjorts hade studien varit en "multipel" fallstudie. Strävan genom studien var att presentera en helhetsbild, det vill säga kontrasterna av existentiell ensamhet i sitt sammanhang.

Ett fall bestod av intervjun med en äldre person, intervjun/erna med hennes/hans närstående samt tillhörande fältanteckningar. Av dessa datakällor gjordes en sekundär analys som innebär att re-analysera data med syfte att besvara nya frågor (Polit \& Beck, 2017). Ett första steg var att gemensamt med seniora forskare sätta samman ett protokoll (Yin, 2009) för att avgöra vad som skulle fokuseras på vid genomläsning och vid lyssnandet på varje intervju. Eftersom jag inte själv hade gjort intervjuerna med de äldre och för att inte ge tolkningsföreträde till några intervjuer var det viktigt att lyssna till intervjuerna med de äldre, läsa transkriberingarna och fältan- 
teckningarna flera gånger. Protokollet var en hjälp för att lyssna och läsa igenom varje intervju på ett liknande sätt. Protokollet innehöll frågor som: Vilken kontext (sammanhang, relationer, situation, organisering, fysisk miljö) befinner sig den äldre i? Vilka fenomen är framträdande i deras (närståendes och sköra äldres) berättelser? Vad uttrycks? Hur kommuniceras det? Hur hanteras det? Finns det avgörande skeden? När varje intervju var genomgången enligt protokollet sammanfattades den äldres och dennes närståendes berättelser samt fältanteckningarna till en mindre berättelse på två till tre sidor med fokus på den äldre personens kontext, hennes/hans upplevelser av existentiell ensamhet och hennes/hans närståendes uppfattningar om detsamma. Tillvägagångssättet ledde fram till 15 konstruerade berättelser som var textnära och totalt omfattade ca 40 sidor.

Nästa steg handlade om att dra slutsatser utifrån de 15 berättelserna genom att identifiera genomgående mönster, det som Yin (2009) benämner som "cross-case conclusions" det vill säga att inte längre titta på berättelserna var för sig utan tillsammans. I detta skede användes tematisk analys (Braun \& Clarke, 2006) som ett verktyg för att på ett metodiskt sätt finna genomgående mönster i de 15 berättelserna. Tematisk analys är lämplig att använda när mönster i texter eftersöks (a.a.). På nytt lästes de 15 berättelserna av mig och seniora forskare oberoende av varandra och därefter diskuterades gemensamt våra intryck av berättelserna. Tre teman av genomgående mönster framkom som handlade om synen på vad som ger mening i livet och vad som gör att en person känner frihet samt vad och hur samhörighet upplevs med andra människor. Analysen gick fram och tillbaka mellan de 15 konstruerade berättelserna och de tre identifierade temana. När inget nytt längre framkom, konstruerades ett typfall per tema för att illustrera kontrasterna mellan äldre personers upplevelser och deras närståendes uppfattningar om existentiell ensamhet.

\section{Beskrivande statistisk analys}

I studie IV gjordes en tvärsnittsstudie som innebär att ett nedslag görs vid ett tillfälle i en viss population (Polit \& Beck, 2017). Att göra en undersökning via en enkät gjorde det möjligt att undersöka många personers uppfattningar om ett givet påstående vid en förutbestämd tidpunkt (a.a.). Deskriptiv statistik (a.a.) användes för att beskriva urvalet och för att beräkna median, spridning och andel procent av de graderade påståendena $\mathrm{i}$ enkäten. Som verktyg för att göra beräkningarna användes SPSS $^{\odot}$ version 24.0. Fritextsvaren strukturerades och sorterades under respektive del av enkäten. Citat valdes ut för att ge exempel på respondenternas fritextsvar. 


\section{Förförståelse}

Min förförståelse i förhållande till mitt avhandlingsarbete handlar om arbetet som sjuksköterska. Mina erfarenheter kommer dels från mitt tidigare arbete inom geriatrisk vård vid äldreboende och sjukhus och dels inom specialiserad palliativ vård. I arbetet med palliativ vård var filosofin att se människan som en helhet i sitt sammanhang. Det har varit en strävan att genom studierna, både avseende hur frågor ställs vid intervjuer och i analysarbetet att vara medveten om min förförståelse för att undvika att förförståelsen fått tolkningsföreträde. Jag har ansträngt mig för att göra förförståelsen synlig för mig själv genom att skriva ner den och i dialog med seniora forskare. En hjälp har också varit att i forskargruppen för LONE-studien finns det forskare inom andra fält än vårdvetenskap såsom teologi och kulturgeografi som tillfört andra perspektiv. Till LONE-studien har även en referensgrupp varit knuten där resultaten från studierna presenterats och därefter diskuterats. På så vis har mina förgivettagna antaganden synliggjorts. 


\section{ETISKA ASPEKTER}

Personcentrering kan användas för att reflektera över forskning som genomförts. Avhandlingens etiska aspekter beskrivs därför utifrån fyra grundläggande värden som personcentrering har som utgångspunkt i synen på forskning: respekt, ömsesidighet, öppenhet och självbestämmande (Jacobs, van Lieshout, Borg \& Ness, 2017). Att ställas inför val ingår i forskningsprocessen (Vetenskapsrådet, 2011). Val har gjorts före, under och efter studierna. Att väga nytta i förhållande till skada är centralt i all forskning (WMA, 2013). Nyttan med studierna bedömdes vara att öka förståelsen för vad existentiell ensamhet är, hur den uttrycks och kommuniceras, kan mötas och hanteras. Att arbeta för en god planering före datainsamling, för ett gott förhållningssätt $\mathrm{i}$ intervjusituationen samt att forskningens resultat kommer samhället till del och gagn tillhör god forskningssed (Vetenskapsrådet, 2011). Studierna är etiskt godkända av Regionala Etikprövningsnämnden i Lund, för studie II och III med Dnr 2014/652 och för studie I, IV och ramberättelse med Dnr 2018/422.

\section{Respekt}

Före intervjuerna, både de i grupp (I, ramberättelse) och de individuella (II, III), fanns det forskningsetiska val att ta ställning till för att värna respekten för de personer som deltog i studierna. För att komma i kontakt med närstående inför studie II identifierades de via intervjuer med äldre personer som genomfördes av en annan doktorand och en forskare inom LONE-studien. Att olika personer genomförde intervjuerna med de äldre och de närstående gjorde det möjligt att värna konfidentialitet och respektera autonomin (Vetenskapsrådet, 2011). Det skulle kunna vara svårt att hålla en öppenhet gentemot det som närstående berättade utan att vara färgad av det som den äldre personen hade talat om. Med detta förfaringssätt kunde vi ärligt säga, om närstående frågade vad den äldre hade berättat om, att vi inte visste. 
Avseende intervjuerna, både de som skedde i grupp (I, ramberättelse) och de som genomfördes individuellt (II, III), fanns risker med att närma sig ett ämne som existentiell ensamhet genom att ämnet kunde vara svårt att samtala om. En annan risk var att ämnet berörde och väckte känslor (Sand \& Strang, 2013) som personen sedan lämnades ensam med. Risken fanns också att någon närstående kände sig utlämnad eller upplevde att de delgett för mycket om den äldre personen eller om sig själva. Några dagar efter intervjuerna (II, III) gjordes därför valet att närstående och de äldre personerna kontaktades på nytt. Avseende intervjuerna i grupp (I) träffades gruppen vid tre tillfällen vilket gjorde det möjligt att följa upp tankar som hade väckts. Detta kan ses som ett sätt att säkerställa att intervjun medförde så liten skada som möjligt och också få veta om intervjun gjort gott eller skadat. Närstående har i telefonsamtalet samt i anslutning till fokusgrupperna uttryckt att det kändes "gott" att få berätta, att någon lyssnade och visade intresse för deras berättelse.

Bergum och Dossetor (2005) beskriver att respekt härstammar från vetskapen om att vi är beroende av varandra. Under intervjun fanns en strävan efter att skapa balans mellan forskare och informant. Bergum och Dossetor (2005), Buber (1962/2013) och McCormack et al. (2017) menar att genom medvetenhet om påverkan åt båda hållen, uppstår ömsesidig respekt. God forskningssed innebär att vara medveten om hur det jag gör påverkar en annan person. Min uppfattning är att intervjuerna, framför allt de i fokusgrupperna (I, ramberättelse), gjorde nytta eftersom deltagarna uttryckte att det var betydelsefullt för dem att få prata med andra som var i en liknande situation.

\section{Självbestämmande}

I studie I fick makar frågan om deltagande samt informationsbrev via en anhörigkonsulent. Om makarna godkände att jag kontaktade dem lämnades namn och telefonnummer ut. Fem personer avböjde medverkan vilket kan ses som ett tecken på att de kände att de själva kunde välja om de ville delta eller ej (I, ramberättelse). En annan risk kan vara att någon av makarna kände sig tvingade att medverka i studien på grund av lojalitet gentemot anhörigkonsulenten. Att garantera att så inte har skett är svårt men vid varje telefonkontakt och inledningsvis vid varje fokusgruppssamtal påmindes om frivilligheten att delta i studien. För att värna de äldre personernas integritet (II, III) förmedlades endast deras namn, samt namn och telefonnummer till deras närstående vidare till mig. Först någon vecka efter att intervjun med den äldre personen hade ägt rum, kontaktades närstående via telefon. Tanken var att de äldre skulle ha möjlighet att berätta för närstående att de blivit intervjuade och att de upp- 
gett deras namn. Vid telefonsamtalet beskrevs studien i korthet med förfrågan om att skicka ett informationsbrev, och därefter skickades informationsbrevet ut. Under telefonsamtalet kunde jag välja hur frågan ställdes (I, II). Enklast var att fråga efter deltagande i en studie om ensamhet istället för att fråga om existentiell ensamhet. Ur forskningsetisk aspekt bör frågan å ena sidan formuleras så korrekt som möjligt men personen ska å andra sidan också kunna förstå vad som efterfrågas (Vetenskapsrådet, 2011). En grundhållning som forskare är att tala sanning (Beauchamp \& Childress, 2013). Därför beskrevs att syftet med intervjun var att få ta del av erfarenheter om en djupare form av ensamhet som ibland benämns som existentiell ensamhet. I varje telefonkontakt gjordes ett val att förmedla frågan så äligt, korrekt och begripligt som möjligt utan att förminska eller förstora ämnet för intervjun. En etisk aspekt är om de närstående skulle kunna känna sig tvingade att delta eftersom de blivit rekommenderade av en annan person (II). Att en tillfrågad närstående (II) valde att inte delta kan anses styrka att frågor om deltagande har ställts på ett sådant sätt att det var möjligt att avböja medverkan.

I samband med intervjun tog närstående (I, II, III, ramberättelse) och de äldre personerna (III) del av och skrev under informerat samtycke. I studie IV där en enkät användes gjordes antagandet att om de besvarade enkäten var det ett godkännande att delta i studien. Denna information fanns även beskriven i informationsbrevet. Ambitionen var att deltagare i samtliga fyra studier skulle veta vad intervjun och enkäten skulle handla om och vad som förväntades av dem. Det är inte enkelt att garantera att så alltid har skett eftersom ett informerat samtycke innehåller flera aspekter. Beauchamp och Childress (2013) delar in informerat samtycke i flera delar. Det handlar först och främst om att personen ska ha kompetens att förstå informationen. Avgörande var att informationsbrevet var formulerat på ett sådant sätt att det var tydligt och enkelt skrivet, utan att utelämna något. Därtill handlar informerat samtycke om att förmedla till deltagaren att de när som helst har rätt att avbryta sin medverkan utan vidare förklaring. Studien byggde på frivilligt deltagande med Helsingforsdeklarationens etiska principer i beaktande (WMA, 2013). Slutligen ingår i informerat samtycke att ge sitt medgivande, det vill säga att samtycka genom sin underskrift (Beauchamp \& Childress, 2013; Vetenskapsrådet, 2011).

\section{Ömsesidighet}

När informerat samtycke hade getts inleddes intervjun (I, II, III, ramberättelse). Att värna om att inte utöva påtryckning under intervjuerna var ett sätt att sträva mot en ömsesidighet som är att ha ett gott etiskt förhållningssätt som forskare för att värna 
deltagarna och för att inte skada (Vetenskapsrådet, 2011). Thornquist (2012) beskriver att $\mathrm{i}$ intervjusituationen finns en ständig avvägning närvarande. Å ena sidan har jag ett ansvar som forskare att få veta något, å andra sidan ska jag verka för en god forskningssed genom att inte utöva påtryckning. Helsingforsdeklarationen (WMA, 2013) beskriver vikten av att ta tid för intervjun, både före, under och efter som ett redskap för att åstadkomma en god intervjusituation.

Under tiden som intervjuerna pågick, både de i grupp (I, ramberättelse) och de individuella (II, III), fanns forskningsetiska val att ta ställning till. De individuella intervjuerna gjordes i par tillsammans med en senior forskare. Thomson (2010) påtalar vikten av att ha en tydlig rollfördelning för att reducera risken för otydlighet i intervjusituationen. Därför berättade vi både inledningsvis under intervjuerna i grupp (I, ramberättelse) och de individuella intervjuerna (II, III) vilka vi var och vilka roller vi hade. Thomson (2010) menar att två intervjuare kan möjliggöra att mer av det som den intervjuade ger uttryck för kan tas tillvara. Ur ett etiskt perspektiv är det väsentligt att inte behöva komma tillbaka för att ställa frågor igen då detta på nytt upptar tid (Vetenskapsrådet, 2011).

Ytterligare en viktig aspekt ur ett etiskt perspektiv var att under intervjun ha i åtanke att de närstående berättade $o m$ en annan person (II). Rimligen fanns det ett och annat tvivel hos den närstående om vad som borde delas, vad som delades och vad som valdes bort att berätta om. Forskaren har ansvar för att vara lyhörd och inte utöva påtryckning (Vetenskapsrådet, 2011). I informationsbrevet för samtliga fyra studier fanns även uppgifter om hur närstående och anhörigkonsulenter kunde komma i kontakt med mig som en möjlighet till uppföljning om behov uppstod.

\section{Öppenhet}

Allt material i en forskningsstudie måste förvaras på ett sådant sätt att inga utanför forskargruppen kan ta del av det och materialet ska presenteras på ett sådant sätt att de äldre personerna, närstående och anhörigkonsulenter inte ska gå att identifiera av en läsare. Materialet hanterades konfidentiellt bland annat genom att kodlistan förvarades skild från intervjuerna och genom att allt material förvarades inlåst. Som forskare är ansvaret att skydda materialet likaså att hålla god ordning på materialet (Beauchamp \& Childress, 2013; Vetenskapsrådet, 2011).

Till god forskningssed hör även att vara öppen med det som studierna visar genom att presentera resultaten i vetenskapliga sammanhang och på andra sätt sprida forsk- 
ningens resultat i samhället. Resultaten från studierna har presenterats vid konferenser så väl nationellt som internationellt. Studierna har publicerats (II, III) samt skickats in för publicering (I) i internationella vetenskapliga tidskrifter med granskningsförfarande. För att nå ut till övriga samhället har besök vid vårdenheter och forum för anhöriga genomförts där resultat har presenterats och diskuterats. En populärvetenskaplig sammanfattning har gjorts av publicerade studier som förmedlats till de enheter som varit med i LONE-studien samt till andra som visat intresse. 


\section{RESULTAT}

Resultatet presenteras i tre delar med fokus på existentiell ensamhet hos sköra äldre personer - ett närståendeperspektiv: 1) Att sakna, men också sträva efter djupare samhörighet, 2) Att vara i, men också uthärda en oönskad separation och 3) Att inte finna, men ändå försöka återskapa mening. Först $\mathrm{i}$ texten presenteras ett inifrånperspektiv, alltså de upplevelser som närstående och äldre berättat om i studie I och III. Därefter presenteras ett utifrånperspektiv där närstående ger sin bild av existentiell ensamhet hos de äldre personerna som står dem nära (II) och de bilder anhörigkonsulenter har av existentiell ensamhet hos de personer de har som uppdrag att stödja (IV). Slutligen presenteras det behov och de önskemål om stöd som framkommer och det stöd som ges (IV, ramberättelse).

\section{Att sakna, men också sträva efter djupare samhörighet}

När närstående berättade om sina egna upplevelser av existentiell ensamhet som make/maka talade de om att de under många år känt en nära samhörighet med en annan person som nu var förändrad eller inte längre levde. Det var svårt att finna nya sammanhang och samtidigt var det svårt att vara kvar i gamla där de alltid hade varit ett par. I sina berättelser uttryckte de en önskan och en vilja att känna samhörighet men samtidigt uttryckte de att de inte mentalt orkade söka sig till nya människor. De beskrev existentiell ensamhet som att längta efter samhörighet men inte orka möta andra människor. De gav exempel på hur de besökt mötesplatser för att försöka träffa andra människor och samtidigt hur de smitit ut bakvägen, eller hur de inte ville vara hemma och vanka, men samtidigt inte orkade vara borta och komma hem för att bli påminda om tomheten (I). Att sakna samhörighet fanns också i sköra äldres upplevelser av existentiell ensamhet. De äldre uttryckte en längtan efter att känna djupare samhörighet och berättade att de kände sig utanför av att vara bland 
människor som de inte delade något med. Sådana situationer gjorde att de kände sig existentiellt ensamma (III).

När närstående beskrev hur de uppfattade existentiell ensamhet hos sin förälder, släkting eller vän handlade det om att de uppfattade att den äldre personen allt mer drog sig undan och avskärmade sig från sin omgivning och därför upplevde existentiell ensamhet (II). Nedan beskriver en närstående till en skör äldre person hur hon uppfattade avsaknad av samhörighet hos sin släkting:

...jag tror det var kyrkan nu angående hennes nittioårsdag, då skulle dom hämta henne, hon skulle komma någonstans...och det var ju inte...hon kände ju inte dom, hon visste ju inte vad det är för något och sen tror jag att det är att hon tror inte att hon passar in. Och sen är hon lite rädd att dom ska prata om sina barnbarn, för det har hon ju inga...(II).

När äldres upplevelser av existentiell ensamhet kontrasterades mot deras närståendes uppfattningar handlade kontrasten om att medan äldre personer uttryckte att de kände sig utanför av att vara bland människor som de inte delade något med försökte närstående på olika sätt, i all välmening, att konstruera ett nytt socialt sammanhang för den äldre personen att tillgå. De äldre uttryckte dock att det var svårt att känna samhörighet med nya människor i ett nytt sammanhang och att de snarare kände sig mer utanför i sådana sammanhang, medan detta inte var synligt för närstående (III).

När anhörigkonsulenterna ombads att skatta vad de bedömde hörde samman med existentiell ensamhet menade 63 procent att "ensamhet" och att "sakna relationer" hörde samman med existentiell ensamhet och i fritextsvaren uppgav de att "känna sig ensam trots människor i sin närhet" hörde samman med existentiell ensamhet (IV).

\section{Stöd i strävan efter samhörighet}

När närstående som var makar berättade om hur de sökte sig till sammanhang för att känna samhörighet på nytt efter sin partners död var närhet ett centralt ord. Berättelserna handlade om att ha familj eller någon vän fysiskt nära såsom att bo nära varandra för att enkelt kunna gå inom och prata en stund. Närhet handlade också om att ha någon som det var enkelt att ringa till för att samtala med en stund när sorg eller tunga tankar kom över. Även sociala medier och olika nätbaserade spel, som "Wordfeud", var sätt att känna närhet och samhörighet med vänner och familj. När närstående istället berättade om existentiellt stöd som de behövde få från andra 
handlade det om att erbjudas samtal. De beskrev att de var viktigt att få prata om det som de varit med om både under tiden som deras partner levde men även efter partnerns död. Makarna berättade att formella samtalsgrupper arrangerade av anhörigkonsulenten eller en organisation som Svenska kyrkan var betydelsefulla. Att gruppen inte bestod av vilka närstående som helst utan av människor som hade liknande erfarenheter som de själva, där de kunde känna igen sig i varandras berättelser, uttryckte de som värdefullt och stödjande. Närstående lyfte också fram de informella samtalen med vänner och familj som betydelsefulla. Närstående upplevde stöd från andra när de kände sig bekräftade och sedda av andra människor i sin omgivning, när andra visade sin omtanke som när någon sa "hej" när de möttes $i$ affären, när de fann ett kort med en hälsning i brevlådan eller när någon gav dem en kram. Att känna sig sedda av människor som stod dem nära, men även från andra människor som de inte hade förväntat sig omtanke ifrån hade betydelse (ramberättelse).

Anhörigkonsulenterna uppgav i enkäten att de gav existentiellt stöd genom att samtala med närstående (87\%) och genom att göra hembesök hos dem (75\%), de organiserade samtalsgrupper för närstående (78\%) och förmedlade kontakt till samtalsgrupper $(73 \%)$. I fritextsvaren uppgav anhörigkonsulenterna att de organiserade samtalsgrupper utifrån specifika ämnen som kunde handla om existentiella behov och att de hade uppsökande verksamhet. De uppgav också att de gav stöd till närstående som behövde det, oavsett relation till en annan person, och de önskade att de kunde nå ut till fler närstående och att de hade mer tid och kunskap. För att kunna ge fler närstående stöd ville de samarbeta mer med andra och de önskade att de inte var ensamma i sin roll som anhörigkonsulenter (IV).

\section{Att vara i, men också uthärda en oönskad separation}

När närstående berättade om sina egna upplevelser av existentiell ensamhet som make/maka till en skör äldre partner talade de om hur det var att förlora sin livskamrat. De hade levt tillsammans under många år och nu gick de igenom en oåterkallelig och oundviklig separation från en person som under många år varit en stor del av deras liv. De berättade om att de förlorade sin partner stegvis, från att känna sig tvungen att ta beslut för sin partner till att partnern slutligen dog. Besluten som närstående refererade till handlade om att besluta om annat boende eller om att de själva inte längre orkade ha sin partner hemma. Existentiell ensamhet väcktes av att känna sig tvingad att ta beslut utan att involvera sin partner, trots att de önskade slippa välja eftersom inget val kändes tillfredsställande. Berättelserna handlade också om att det var partnern som valde att lämna hemmet genom att flytta till ett 
annat boende och hur de närstående då upplevde existentiell ensamhet av att bli övergivna och lämnade ensamma kvar. Närstående berättade om längtan efter livet tillsammans, sådant som livet en gång var och samtidigt en vetskap om att förändringen som skedde var oåterkallelig och beständig. De berättade om hur de förut levt i ett $v i$ men nu måste de istället börja tänka jag. Att tänka jag istället för vi var inget som kom spontant utan en riktad, medveten tanke krävdes. Närståendes berättelser handlade om hur det var att uppleva sig som en halv människa när de inte längre kände sig hela och att det tog tid att vänja sig vid att livskamraten var förändrad eller inte längre fanns. I förändringen från att vara ett vi till att vara endast ett jag framträdde existentiell ensamhet (I). Nedan beskriver en make om hur det var när han förlorade sin hustru:

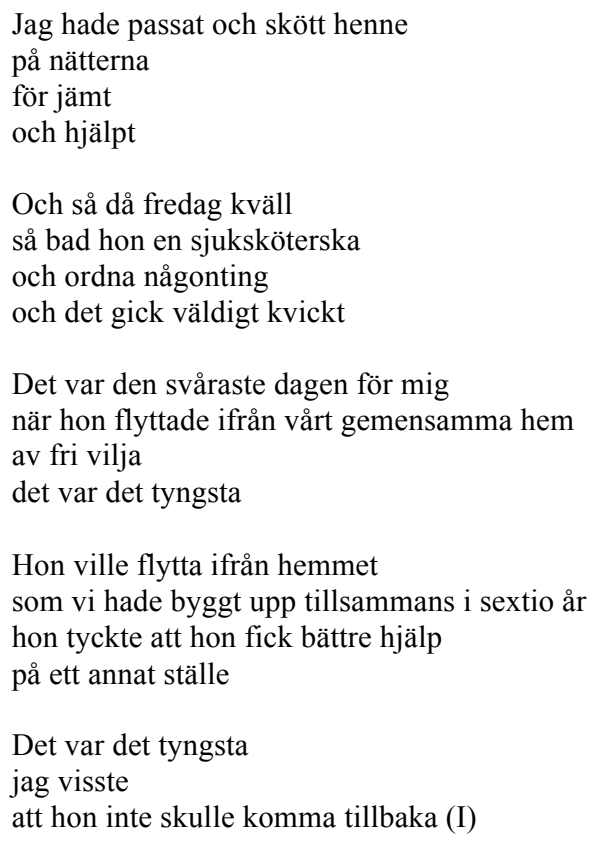

Att vara i en oönskad separation fanns också i sköra äldre personers upplevelser av existentiell ensamhet som handlade om att separeras från sitt eget välkända jag. De äldre uttryckte att $\mathrm{i}$ takt med att deras fysiska kropp blev allt mer försämrad förlorade de förmågan att själva bestämma och att kunna göra sådant som de själva ville och hade kunnat göra tidigare i livet (III). 
Separationen från sitt eget välkända jag var även synligt när närstående beskrev hur de uppfattade existentiell ensamhet hos sin förälder, släkting eller vän. De uppfattade att i takt med att den äldre blev allt mer försämrad i sin fysiska kropp begränsades möjligheten att vara självständig och oberoende. Försämringen i kroppen innebar också minskad möjlighet att kunna välja vilken plats de ville vara på. Att vara begränsad i sin kropp, beroende av andra och hänvisad till en viss plats handlar om förlust av frihet som leder till existentiell ensamhet. Närstående uppfattade vidare att förluster handlade om att vara i en process av att släppa taget om långvariga relationer med livskamrater och vänner eller att släppa taget om en särskild plats, som att flytta från sitt hem. Det handlade också om att släppa taget om minnessaker. De närstående uppfattade att den äldre upplevde existentiell ensamhet när förlusten av sådant som var viktigt skapade en känsla av tomhet (II).

Sextiotvå procent av anhörigkonsulenterna angav att existentiell ensamhet hörde samman med "döende", "död" och "förluster". I fritextsvaren beskrevs att "sorg" och "hopplöshet" hörde samman med existentiell ensamhet (IV).

\section{Stöd i en oönskad separation}

När närstående som var makar berättade om hur de var i, men också uthärdade, en oönskad separation talade de om behovet av att möta andra som var i en liknande situation genom att söka sig till föreningar och organiserade sammankomster vid anhörigcentra eller via pensionärsorganisationer. Närstående berättade också om hur de såg, talade med och kände doften av sin partner även om den andre inte längre levde eller hade flyttat till ett annat boende och att de i dessa förnimmelser fann stöd, tröst och ro. Förnimmelserna kunde beskrivas såhär:

\footnotetext{
... förvånande och ibland känns det lite trösterikt...//...trösterikt, ja, när inte allt klipps av...//...min man möter jag ju många, många gånger i landet mellan vakenhet och dröm...//...Så hör jag ju honom...(ramberättelse)
}

Ordet tid var centralt när närstående berättade om existentiellt stöd som de behövde få från andra. De talade om tid att tänka, tid att vara ifred, men inte för länge, och tid att vänja sig vid förlusten (ramberättelse) men endast 30 procent av anhörigkonsulenterna uppgav att de gav stöd till närstående vars partner var död. Fyrtiofem procent angav att de hade tid i sin tjänst för att ge existentiellt stöd och fyra procent angav att de gav stöd till närstående utanför sin arbetstid (IV). 


\section{Att inte finna, men ändå försöka återskapa mening}

När närstående berättade om sina egna upplevelser av existentiell ensamhet som make/maka till en skör äldre person talade de om att befinna sig i en okänd situation som de hade svårt att finna mening i. De beskrev det som att navigera i en okänd situation och samtidigt ifrågasätta sig själva. De refererade till att andra människor kan säga att de förstår, och även att de själva hade tänkt eller sagt så till andra tidigare, men nu menade de att det inte går att förstå, inte förrän de själva varit med om något liknande. De berättade också att sådana här känslor och situationer går det inte att värja sig ifrån. Strävan genom livet kan vara att skydda sig, att bli immun, men det är omöjligt att bli immun mot svåra situationer. Upplevelsen beskrevs som att vara instängd i en bubbla, avgränsad i ett vakuum. Att vara i en situation där både livet och självet ifrågasätts (I). Nedan beskriver en kvinna sin upplevelse av existentiell ensamhet som att vara instängd $i$ en bubbla:

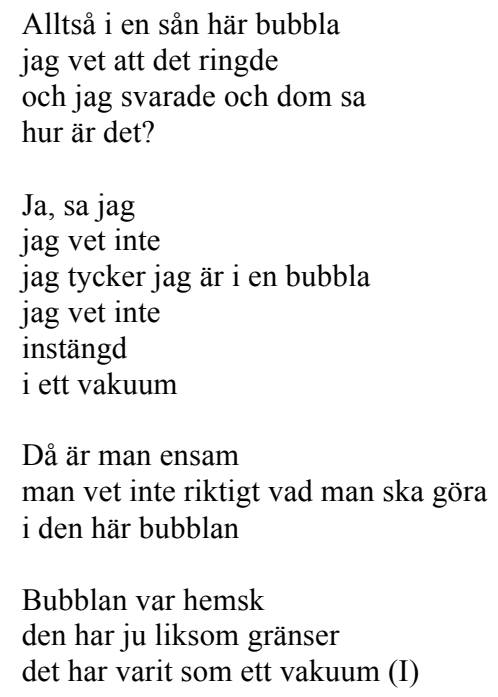

Att inte finna mening fanns även i sköra äldre personers upplevelser av existentiell ensamhet. De äldre uttryckte att de hade ett minskat inflytande över sitt eget liv när de inte längre gavs möjlighet att uttrycka sina önskemål eller att göra val i sin vardag (III).

När närstående istället beskrev hur de uppfattade existentiell ensamhet hos sin förälder, släkting eller vän handlade det om att de såg hur den äldre blev allt mer avskärmad från sin omgivning. Gemenskapen med andra människor avtog och att det 
var svårt för den äldre att känna sig förstådd av vårdpersonalen som kom för att ge vård. De uppfattade att livet blev allt mer avskärmat för den äldre och att livet på grund av det blev allt mer meningslöst (II).

När äldres upplevelser av existentiell ensamhet kontrasterades mot deras närståendes uppfattningar handlade kontrasterna om att de äldre upplevde att beslut togs $a t$ dem snarare än tillsammans med dem medan närstående relaterade äldres existentiella ensamhet till att de gav upp och slutade att kämpa, som om ingenting var viktigt för dem längre. Närstående försökte på olika sätt att uppmuntra, kompensera och underlätta för den äldre genom att hjälpa till mer än tidigare, till exempel genom att hjälpa dem att fatta beslut. Kontrasterna handlade också om väntan. De äldre upplevde att dagarna handlade om att vänta på vårdpersonal, vänta på närstående, vänta på att äta, vänta på att få hjälp till toaletten, vänta på möjlighet att komma ut. Närstående försökte på olika sätt att återskapa mening i den äldres liv genom att föreslå aktiviteter och sysselsättning. I de äldres berättelser var det inte aktiviteter i största allmänhet som efterfrågades utan en längtan efter att vara av betydelse för någon annan. De äldre uttryckte att få gjorde saker tillsammans med dem utan endast för dem (III).

Sjuttioåtta procent av anhörigkonsulenterna angav att existentiell ensamhet hörde samman med "livet" och "mening". I fritextsvaren uppgav de att "tankar om existensen" hörde samman med existentiell ensamhet (IV).

\section{Stöd i att återskapa mening}

När närstående som var makar berättade om hur de inte fann mening i sin situation men hur de ändå försökte återskapa ett meningsfullt liv talade de om betydelsen av att skingra sina tankar genom att ha meningsfulla och roliga aktiviteter att göra och att se fram emot. Det handlade om att ha fysiska aktiviteter för att bli trött i kroppen och på så sätt kunna sova gott, känna sig duktig och för att få ur sig det som kändes tungt inombords. De berättade också om aktiviteter som handlade om att kunna göra något för någon annan för att känna att de bidrog och att vardagen fick mening. Aktiviteterna kunde vara formella såsom att vara volontär vid ett äldreboende eller vid ett sjukhus. Aktiviteterna kunde också vara informella såsom att hjälpa till med barnbarn eller att vara hundvakt. De sökte även mening från en annan dimension. Några fann stöd i en tro, av att be, läsa i Bibeln, fira gudstjänst och av att sjunga välkända psalmer. Medan andra fann ett sådant stöd genom att vistas i naturen, ge- 
nom att lyssna till musik eller av att ta del av litteratur. Såhär kunde ett sådant stöd beskrivas:

...jag får vara överlämnad och tro på en gudomlig kraft...//...att liksom att ha en tro och bottna i kan vara någonting som hjälper oss människor...//...mmm...//...och sen har vi ju inte alla det, så är det ju också...men att det kan vara naturen för någon annan...och litteraturen...(ramberättelse)

Närstående berättade vidare om betydelsen av att se på foton som påminde om minnen från livet. De beskrev även att de kände en slags mening i sin tillvaro och över de beslut som de tagit när de kände att deras partner mådde väl och hade det bra oavsett om han/hon bodde hemma eller vid ett äldreboende (ramberättelse).

Anhörigkonsulenterna uppgav i enkäten att de gav stöd till vårdpersonal (27\%) eller till volontärer (18\%) som mötte närstående. Anhörigkonsulenterna skattade att de gav stöd till närstående vars partner bodde hemma (75\%), vid ett äldreboende (71\%) eller ett avlastningsboende (69\%). Det var inte så vanligt att de arrangerade föreläsningar för närstående om existentiella behov (37\%) eller utbildning till vårdpersonal om existentiellt stöd till närstående (12\%). Fyrtiofyra procent av dem hade erfarenhet av att möta existentiell ensamhet och 27 procent uppgav att de hade tillräcklig kunskap för att möta existentiell ensamhet (IV). 


\section{METODOLOGISKA ÖVERVÄGANDEN}

Syftet med forskning är att generera ny kunskap, nya insikter och utökad förståelse men det finns alltid en risk för felkällor och tolkningar som kan leda till alltför långtgående slutsatser. Så även i denna avhandling. Därför är det viktigt att kritiskt granska den forskning som genomförs och att diskutera dess kvalitet utifrån trovärdighet, det som Guba (1981) benämner som trustworthiness. Kvalitativa studier granskas oftast utifrån begreppen tillförlitlighet (credibility), överförbarhet (transferability), verifierbarhet (dependability) och pålitlighet (confirmability). Kvantitativa studier granskas oftast utifrån intern validitet (internal validity), extern validitet (external validity), reliabilitet (reliability) och objektivitet (objectivity) (Guba, 1981; Polit \& Beck, 2017). Kvalitetsbegreppen har översatts från engelska till svenska på olika sätt av olika författare. I den här avhandlingen har jag i huvudsak använt Gubas begrepp (1981) och därför anges utöver det svenska begreppet även vilket engelskt begrepp som avses. Guba (1981) beskriver fyra aspekter som bör vara vägledande i granskning av forskning oavsett om studierna är av kvalitativ eller kvantitativ art som handlar om studiers äkthet - truth value (tillförlitlighet respektive intern objektivitet), användbarhet - applicability (överförbarhet respektive extern validitet), noggrannhet consistency (verifierbarhet respektive reliabilitet) och neutralitet - neutrality (pålitlighet respektive objektivitet). Kvalitetsaspekterna diskuteras gemensamt för de kvalitativa studierna (I, II, III, ramberättelse) och den kvantitativa studien (IV). Guba (1981) menar att tillförlitlighet är den viktigaste kvalitetsaspekten i studier. Således ges den delen av kvalitetsgranskningen mest utrymme.

\section{Tillförlitlighet och intern validitet}

Tillförlitlighet (credibility) avseende de kvalitativa studierna (I, II, III, ramberättelse) och intern validitet (internal validity) i den kvantitativa studien (IV) handlar om att avgöra om resultaten kan anses vara sanna, riktiga och äkta (Guba, 1981), om 
det som avsågs att studeras verkligen har undersökts (Shenton, 2004) och om resultaten ger en trovärdig bild av deltagarnas verklighet och av det som de har delgett (Polit \& Beck, 2017).

Ett hot mot tillförlitligheten i de studier som ingår i avhandlingen är om det verkligen är fenomenet existentiell ensamhet som har studerats eftersom existentiell ensamhet beskrivs som sammanflätad med andra former av ensamhet och med andra mänskliga känslor och fenomen som sorg, ångest eller depression (Applebaum, 1978). En strävan att fokusera på existentiell ensamhet har varit genomgående $i$ hela avhandlingsarbetet. Risken fanns dock att berättelserna från närstående och äldre personer skulle komma att handla om andra former av ensamhet än om existentiell ensamhet. För att reducera denna risk har flera åtgärder vidtagits i datainsamling och i analysförfarande. När studierna som ligger till grund för avhandlingen inleddes fanns det sparsamt med empiriska studier om existentiell ensamhet och därför valdes en explorativ design. Med ett induktivt förhållningssätt har öppenhet präglat såväl val av intervju- som analysmetoder (Polit \& Beck, 2017).

Studierna inleddes med att gemensamt i forskargruppen för LONE-studien arbeta fram informationsbrev till informanter och intervjuguider. Det finns en risk att deltagarna i respektive studie (I-IV) inte förstod vad existentiell ensamhet innebar i informationsbreven, intervjufrågorna eller påståendena i enkäten till fullo. Forskargruppen lade därför särskilt stort vikt vid att utforma informationsbrevet och ingångsfrågan i intervjuerna. I samtliga informationsbrev beskrevs existentiell ensamhet som en djupare känsla av ensamhet, som att stå ensam och utlämnad åt sig själv och som en känsla som verkar uppträda när hotande händelser såsom förluster av olika slag drabbar oss. Därtill testades intervjuguiden genom pilotintervjuer. Eftersom samma intervjuguide användes i studie I och II testades den enbart inför de första intervjuerna. Enkäten (IV) utvecklades enbart för denna studie då inga vedertagna befintliga enkäter fanns tillgängliga. Intern validitet, det vill säga om enkäten bedömdes undersöka det som avsågs, testades dels genom att medlemmar i forskargruppen för LONE- studien besvarade enkäten, en form av "face validity", och dels genom att en anhörigkonsulent besvarade den med hjälp av "think-aloud-method". Samtliga dokument för studie I-IV har diskuterats i forskargruppen för LONEstudien.

Tillförlitlighet handlar också om urvalet i studierna. Strävan har varit att söka variation i de kvalitativa studierna för att fånga flera aspekter av fenomenet som under- 
söks (Polit \& Beck, 2017), i detta fall existentiell ensamhet. I studie I var strävan att nå både makor och makar från två olika kommuner, både de som levde tillsammans med en skör äldre partner och de som tidigare hade tagit hand om en skör äldre partner men blivit änka eller änkling. Det fanns en risk att de som lever tillsammans med en skör äldre partner i nuet står inför flera situationer med existentiella utmaningar som tankar om att den äldre behöver flytta från det gemensamma hemmet och sorg över att vara på väg att förlora sin livskamrat. För att reducera denna risk och för att få variation i urvalet var strävan att inkludera informanter som både levde tillsammans med sin partner samt informanter vars partner inte längre levde. Målet var att nå de som varit änka/änkling i minst ett år men max i fem år. Tidsaspekten handlade om att det inte skulle vara för nära i tid som partnern hade dött men inte heller att det skulle ha gått allt för lång tid. Vid intervjuerna blev det tydligt att de närstående kunde berätta i detalj om den sista tiden tillsammans och särskilt om dagen när deras partner hade flyttat eller dött. I studie II och III nåddes närstående via den äldre personen som ombads att lämna uppgifter på någon eller några som stod dem nära som vi fick intervjua. Eftersom de äldre själva bestämde vem som skulle intervjuas fanns det därmed inte samma möjlighet att påverka variationen i urvalet. Ytterligare en aspekt avseende tillförlitlighet (II, III) var att även om det var de äldre som uppgav en eller flera personer som stod dem nära fanns det en risk att de som vi intervjuade inte stod den äldre tillräckligt nära för att ha kunnat uppfatta den äldres existentiella ensamhet. För att reducera denna risk tillfrågades närstående om hur nära deras relation till den äldre var. Samtliga närstående karakteriserade sin relation till den äldre personen som nära eller mycket nära (II, III). Ett hot mot intern validitet i studie IV handlar om hur tillförlitliga enkätsvaren var. Det kan finnas en risk att respondenterna missförstod frågorna. För att försöka reducera den risken beskrevs existentiell ensamhet $\mathrm{i}$ informationsbrevet. I enkäten gavs även utrymme för fritextsvar. Via dessa svar hade vi också möjlighet att bedöma om anhörigkonsulenterna hade förstått frågorna på det sätt som avsågs. För att reducera risken att deras svar avsåg någon annan åldersgrupp än just äldre personer, användes endast de enkäter där anhörigkonsulenterna angett att de helt eller delvis hade en tjänst som var inriktad på att ge stöd till närstående till äldre personer.

Genom studierna har olika datainsamlingsmetoder använts. Detta sätt kan ses som triangulering, det vill säga att utforska ett och samma fenomen på flera olika sätt och med olika perspektiv (Guba, 1981). Detta var viktigt eftersom existentiell ensamhet ur ett närståendeperspektiv är sparsamt utforskat. Intervjuerna i grupp gav insikt om närståendes egna upplevelser (I). I studie I genomfördes intervjuerna vid tre uppre- 
pade tillfällen vilket gjorde det möjligt att följa en och samma grupp över tid. Guba (1981) rekommenderar detta tillvägagångssätt, så kallat "prolonged engagement", vilket gör det möjligt att följa upp oklarheter och fördjupa samtal. De individuella intervjuerna i studie II gav ett andrahandsperspektiv där närstående delgav sina uppfattningar om de äldres existentiella ensamhet. Slutligen gav enkäten ytterligare ett perspektiv genom att fånga in anhörigkonsulenters syn på existentiell ensamhet och närståendestöd i existentiella frågor (IV). En av vinsterna med triangulering är att flera aspekter av existentiell ensamhet har belysts.

Ett annat hot mot tillförlitligheten i studierna är ämnet för intervjuerna. Existentiell ensamhet är ett komplext fenomen som kan vara svårt att dela med andra (Bolmsjö et al., 2018). På grund av ämnets karaktär genomfördes merparten av de individuella intervjuerna och samtliga fokusgruppsintervjuer av mig tillsammans med en senior forskare som var väl förtrogen med intervjuer och att samtala om existentiella frågor. I fokusgrupper är rekommendationen att det ska vara två personer som genomför intervjun, en som leder och en som observerar (Krueger \& Casey, 2015). Det finns dock en risk att ett maktförhållande kan uppkomma när två personer genomför individuella intervjuer (Thomson, 2010). För att reducera denna risk berättade vi inledningsvis vilka vi var och vilka roller vi hade. Vi tänkte också på att placera oss på ett sådant sätt att det skulle främja dialog och samtal. Det fanns en farhåga att informanterna skulle berätta om social eller emotionell ensamhet snarare än om existentiell ensamhet. För att reducera risken för detta inleddes intervjuerna, både de individuella och de i grupp, med en fråga om hur informanterna såg på ensamhet generellt och först där ställdes frågor om existentiell ensamhet, alltså en djupare form av ensamhet. I intervjuerna efterfrågades och uppmuntrades till svar i form av berättelser för att försöka förstå hela sammanhanget när närstående upplevde egen existentiell ensamhet, eller uppfattade existentiell ensamhet hos den äldre i deras närhet. I studie III blev fältanteckningarna betydelsefulla för att förstå sammanhanget som den äldre personen befann sig i. I intervjuerna var det också viktigt att nå ett djup. Längden på intervjun är en viktig förutsättning för att kunna nå ett djup i de frågor som diskuteras. De individuella intervjuerna i studie II och III varade i ungefär en timme och fokusgrupperna i studie I varade i ungefär två timmar. Ett annat mått på tillförlitlighet är om antalet deltagare i en fokusgrupp är tillräckligt många för att åstadkomma interaktion i gruppen, men inte fler än att samtliga deltagare får utrymme att delge sin upplevelse av det undersökta fenomenet. Krueger och Casey (2015) menar att när djup eftersträvas är det önskvärt att gruppen består av fyra till sex personer. I studie I kom varje grupp slutligen att bestå av fem personer. 
Vidare handlar tillförlitlighet om i vad mån resultatet är trovärdigt (Guba, 1981). Olika metoder har använts för att analysera data. Det finns alltid en avvägning avseende vilken analysmetod som ska, bör och kan användas (Polit \& Beck, 2017). Att använda tre olika sätt att analysera intervjutext har varit viktigt för att kunna undersöka ett relativt outforskat fenomen men också ett sätt att belysa upplevelser, uppfattningar och kontraster. Valet av analysmetod diskuterades i forskargruppen redan i designfasen men även inför att analysen skulle påbörjas. Hermeneutisk analys (Gadamer, 1960/1990; Schuster, 2006) valdes för att ge möjlighet att tolka och förstå närståendes egna upplevelser av existentiell ensamhet och poem användes för att tydliggöra resultatens innebörd för läsaren (I). Tolkningen var viktig för att nå närståendes subjektiva upplevelse. I studie II och i analysen av närståendes behov av stöd (ramberättelse) användes innehållsanalys (Hsieh \& Shannon, 2005) för att på ett utforskande och öppet sätt analysera närståendes upplevelser och uppfattningar. Både innehållsanalys (II, ramberättelse) och tematisk analys (III) är analysmetoder som håller sig nära texten, är utforskande till sin natur och saknar krav på teorianknytning (Hsieh \& Shannon, 2005; Braun \& Clarke, 2006). Därtill har citat lyfts ut för att ge exempel på närståendes upplevelser och uppfattningar (I, II) och berättelser i form av fallbeskrivningar (III) för att belysa kontraster mellan upplevelser och uppfattningar. Studie III genomfördes som en fallstudie då case-metodik syftar till att undersöka hur ett fenomen framträder i sitt sammanhang (Yin, 2009). Eftersom syftet var att kontrastera äldres upplevelser mot närståendes uppfattningar var det viktigt att se uppfattningarna och upplevelserna i sitt sammanhang. Här var fältanteckningarna viktiga för att få en förståelse för just sammanhanget. I analysen av enkätsvaren i studie IV fanns tankar om att göra subgruppsanalyser till exempel mellan utbildning och syn på existentiellt stöd. Det visade sig dock vara omöjligt då svarsfrekvensen var för låg. På grund av den låga svarsfrekvensen (36\%) blev grupperna små och beslutet blev därför att avstå från att göra subgruppsanalyser.

För att öka tillförlitligheten involverades flera personer i analysarbetet i de kvalitativa studierna (I, II, III, ramberättelse). Att vara flera personer i analysprocessen reducerar risken för att endast ett perspektiv ska bli rådande (Polit \& Beck, 2017). Analysarbetet har i första hand drivits av mig med seniora forskares involvering $\mathrm{i}$ olika skeden av analysen. I studie I användes det som Guba (1981) benämner som "member checks" som innebär att deltagarna ges möjlighet att verifiera tolkningen. Eftersom studien genomfördes som fokusgrupper i flera steg fanns möjlighet att börja nästkommande träff med en sammanställning av vad som diskuterats vid tillfället innan och därmed fick deltagarna möjlighet att verifiera en preliminär tolkning 
av föregående sammankomst. Ett hot mot intern validitet i den kvantitativa studien (IV) handlar om korrekthet i data. För att säkerställa att det var korrekt information som "matades in" automatiskt via enkätverktyget till SPSS granskades data manuellt av mig tillsammans med en senior forskare.

Därtill är en referensgrupp knuten till LONE-studien. Referensgruppen består av både män och kvinnor i varierande ålder från ca 50 till drygt 90 år. Medlemmarna $i$ referensgruppen har olika yrken eller yrkesbakgrund. I referensgruppen har resultaten från studierna presenterats och diskuterats och deltagarna har uttryckt att de känner igen resultaten utifrån sina egna erfarenheter av att uppleva och möta existentiell ensamhet och att ge och få existentiellt stöd.

\section{Överförbarhet och extern validitet}

Överförbarhet (transferability) avseende de kvalitativa studierna (I, II, III, ramberättelse) och extern validitet (external validity) i den kvantitativa studien (IV) handlar om att bedöma resultatens användbarhet och tillämpbarhet $i$ ett annat sammanhang och bland andra personer eller grupper än där studien genomfördes (Guba, 1981; Polit \& Beck, 2017). Extern validitet kan också benämnas som en studies generaliserbarhet (Guba, 1981).

Studierna är uteslutande genomförda i en svensk kontext. Även om variation i urvalet eftersträvades var det endast en informant med annan bakgrund än svensk (II, III). I studie I hade makarna levt tillsammans under lång tid, i genomsnitt 50 år, och i studie II och III var en övervägande del av informanterna söner eller döttrar till en skör äldre person. Det är därför svårt att veta om resultaten kan överföras till att gälla personer där relationerna ser annorlunda ut. Vidare är de äldre personerna som de närstående berättar om sköra, det vill säga i behov av varaktig vård och omsorg, vilket kan ha medfört större fokus på det fysiska hälsotillståndets betydelse för existentiell ensamhet (II), än vad det hade haft om andra grupper studerats.

Svarsfrekvensen i studie IV var låg (36\%) vilket är ett hot mot den externa validiteten (Denscombe, 2009) då det finns en risk att urvalet inte var representativt för hela gruppen anhörigkonsulenter. För att försöka få en högre svarsfrekvens skickades två påminnelser ut varav den andra påminnelsen skickades ut på en annan veckodag och vid en annan tidpunkt än den första. Sammansättningen av anhörigkonsulenter avseende ålder, kön och andel mindre och större kommuner överensstämmer dock med 
en rapport från Nka (Winquist, 2014:1) vilket indikerar att ett representativt urval av anhörigkonsulenter besvarat enkäten.

\section{Verifierbarhet och reliabilitet}

Verifierbarhet (dependability) avseende de kvalitativa studierna (I, II, III, ramberättelse) och reliabilitet (reliability) i den kvantitativa studien (IV) handlar om noggrannhet, det vill säga att avgöra om studiens genomförande är tillräckligt väl beskriven för att kunna genomföras på nytt av någon annan och då komma fram till ett liknande resultat eller utfall (Guba, 1981; Polit \& Beck, 2017).

Strävan genom studierna har varit att återge tillvägagångssätt via beskrivning $i$ text och i figurer. Därtill finns citat återgivna för att kunna följa vad informanterna delgett under intervjuerna och hur tolkningen vuxit fram. Avseende reliabilitet i studie IV finns enkäten beskriven samt sammanfattningar av svaren på enkätens fritextsvar. Därtill presenteras enkätens frågor och påståenden i Appendix I.

\section{Pålitlighet och objektivitet}

Pålitlighet (confirmability) i de kvalitativa studierna (I, II, III, ramberättelse) och objektivitet (objectivity) i den kvantitativa studien (IV) handlar om studiens neutralitet genom att läsaren ska ges möjlighet att avgöra om resultaten speglar det som deltagarna har berättat eller skattat eller om resultaten är präglade av forskarens förförståelse (Guba, 1981; Polit \& Beck, 2017).

Pålitlighet i samband med de individuella intervjuerna handlar om att inte frågorna förändras i takt med att forskaren utökar sin förståelse för fenomenet som undersöks (Guba, 1981). För att reducera denna risk användes en intervjuguide (I, II, III). Kristensson Uggla (2019) menar att som forskare är man ofrånkomligen sammanflätad med den verklighet som man försöker förstå. Inom hermeneutiken (I) ska förförståelsen användas och tas tillvara men med varsamhet och medvetenhet (Gadamer, 1960/1990). I innehållsanalys (Hsieh \& Shannon, 2005) (II, ramberättelse) och tematisk analys (Braun \& Clarke, 2006) (III) beskrivs förförståelsen som viktig att medvetandegöra och på så sätt försöka hålla i bakgrunden. Jag har arbetat med min förförståelse genom att redogöra för den genom studierna. Likaså har seniora forskare som varit med i intervjuer och i analysarbete uppmärksammat mig på när förförståelse eller förgivettagna föreställningar varit framträdande. Det finns fynd som gjort mig förvånad som att existentiell ensamhet hör samman med relationer. Likaså finns det fynd som i viss mån gjort mig besviken som att existentiell ensamhet inte 
låter sig avgränsas. Analysarbetet har präglats av det som Kristensson Uggla (2019) skriver om som att vara ömsom deltagare ömsom åskådare i en strävan efter att både ha närhet och distans till materialet som analyseras. Ytterligare en risk som kan påverka neutraliteten $i$ analysen är det som benämns som socialkonstruktion som handlar om de föreställningar som finns om hur vi som personer förhåller oss till varandra beroende på vilken roll vi har (Kristensson Uggla, 2019). Till exempel kan det finnas föreställningar om hur en son ska tala om sin far eller en dotter om sin mor som var viktigt att vara medveten om, särskilt i studie II och III.

Eftersom jag gjorde intervjuerna med de närstående men inte med de äldre personerna finns det en risk att det påverkade analysen i studie III. En senior forskare som inte hade varit med vid intervjuer vare sig med de äldre eller med närstående var viktig för pålitligheten i analysarbetet. För att reducera risken för att ett synsätt ska ges tolkningsföreträde har de seniora forskarna erfarenheter från olika kunskapsområden som omvårdnad av äldre, sjukhusvård, teologi och kulturgeografi, vilket har varit en tillgång i avhandlingsarbetet.

Avseende objektivitet i studie IV fanns det en risk att enkäten innehöll frågor om sådant som inte var relevant att fråga anhörigkonsulenterna om. För att reducera denna risk byggde enkäten på den kunskap som erhållits i tidigare studier och utgick från den information som fanns tillgänglig via $\mathrm{Nka}$ om anhörigkonsulentens funktion. Enkäten pilottestades och diskuterades gemensamt med seniora forskare. Möjligheten till öppna svar bidrog också till att anhörigkonsulenterna kunde framföra egna åsikter och tankar. Det var också viktigt att vara flera personer som granskade skattningar och svar i enkäten. 


\section{DISKUSSION}

Denna avhandling fokuserar på existentiell ensamhet hos sköra äldre personer och har ett närståendeperspektiv. Närståendeperspektivet omfattar ett inifrånperspektiv via närståendes egna upplevelser av existentiell ensamhet (I). Närståendeperspektivet omfattar också ett utifrånperspektiv på de äldre genom att belysa närståendes uppfattningar om de äldre personernas existentiella ensamhet (II). Därutöver har närståendes uppfattningar kontrasterats mot äldres upplevelser (III) och närståendes och anhörigkonsulenters syn på stöd i existentiella frågor undersökts (IV, ramberättelse). Avhandlingens resultat visar att existentiell ensamhet framträder särskilt i situationer av att vara i en oönskad separation, att sakna samhörighet och att inte finna mening. Samtidigt visar resultatet att närstående strävar efter att finna nya sammanhang där de kan känna samhörighet och efter att på nytt finna mening med livet. Resultaten kommer att diskuteras med utgångspunkt från filosofer och på slutet vävas samman med det personcentrerade förhållningssättet som presenterades inledningsvis i denna avhandling. Förhållningssättet handlar om en strävan efter att se varje persons behov och önskemål i sitt sammanhang och att tillgodose dessa behov och önskemål (McCormack \& McCance, 2017; Dewing et al., 2017).

\section{Att balansera mellan det som var och det som ska bli}

Existentiell ensamhet upplevs ofta i en övergångsfas i livet när människor befinner sig i en process mellan det som varit, det som är okänt och det som kommer i framtiden. Ett sådant exempel är närstående som befinner sig i en oundviklig separation från sin partner (I). Studiernas resultat visar att de närstående navigerar, själva men också tillsammans med den äldre, i en okänd tillvaro. Situationen gör att de känner ambivalens över beslut som de tidigare tagit och beslut som de behöver ta i framtiden, samtidigt som de tvivlar på meningen i sin nuvarande situation (I). Detta gör att de upplever existentiell ensamhet. Ett annat exempel är närståendes uppfattningar 
om äldres existentiella ensamhet vid försämring av den äldres fysiska förmågor. Förändringen gör det svårt för närstående att göra sådant som de tidigare brukade göra, och nu är det svårt att hitta nya sätt att vara tillsammans (II). Resultaten är i linje med begreppsanalysen av Bolmsjö, Tengland och Rämgård (2018) som beskriver att existentiell ensamhet kan framträda mer tydligt $i$ övergångsfaser i livet. Filosofen Karl Jaspers (1971/1995) menar att människan genom livet befinner sig i ständig transition mellan det som varit, det som är och det som ska komma i framtiden. I rörelsen mellan dessa olika faser finns ångest men också frihet. Jaspers menar också att allt som existerar genomgår övergångsfaser och att detta tillhör livet. Han benämner denna övergång från en fas till en annan som att människan transcenderas genom att försättas i en gränssituation för att kunna växa och mogna. Gränssituationen beskrivs inte som ett statiskt och bestämt tillstånd utan snarare som en process i att balansera mellan olika val och ställningstaganden. Bakom detta antagande ligger människans förmåga att själv kunna göra fria val. Filosofer som Sören Kierkegaard (1844/1997) och Jean-Paul Sartre (1947/2007) menar att livet består av situationer som innebär val. Val som är existensens villkor. Att vara i en gränssituation handlar om att ställas inför existentiella val (Jaspers, 1971/1995) och Sartre menar att de svåra valen ger ångest. Resultaten från studierna visar att närstående upplever existentiell ensamhet i de val som de måste göra i gränsövergångar som förändrar deras tidigare relationer.

Att vara i en gränssituation handlar alltså om val och ställningstaganden men också om strävan efter mening (Jaspers, 1971/1995). Människans sökande efter mening beskrivs som en kraft i livet och även om meningen förändras genom livet upphör strävan efter mening aldrig att finnas (Frankl, 1946/2006). Frankl menar att meningen med livet kan uppnås genom att utföra en handling, som när närstående ger livet en mening genom att hjälpa till med barnbarn (ramberättelse). Frankl menar också att mening kan uppnås genom att känna värde av att uppleva något eller någon, som då närstående berättar om hur betydelsefullt det är att få möjlighet att möta andra människor i en liknande situation som de själva befinner sig i (ramberättelse). Samtidigt uttrycker närstående hur svårt det kan vara att finna mening i sin situation (I) eller hur de ser att den person som de står nära inte finner mening och på så vis upplever existentiell ensamhet (II). Resultaten i denna avhandling visar att anhörigkonsulenter arrangerar samtalsgrupper där närstående kan träffas och dela erfarenheter (IV). Denna aktivitet är ett sätt att få veta vad närstående behöver för att känna mening i sin situation. 


\section{Att längta efter gemenskap och förankring}

Existentiell ensamhet verkar framträda i längtan efter gemenskap och förankring med någon eller något. Resultaten visar att när närstående berättade om en äldre förälder, vän eller ett syskon som stod dem nära och om dennes existentiella ensamhet, så uppfattade de existentiell ensamhet som att livet blev allt mer tomt för den äldre (II). Detta var också synligt i de äldre personernas egna upplevelser (III). Samtidigt visar resultaten kontraster mellan närståendes uppfattningar om äldres existentiella ensamhet, och de äldre personernas egna upplevelser. Kontrasterna handlade om att närstående, som såg de äldres längtan och behov av gemenskap, försökte förmå dem att delta i aktiviteter, medan de äldre personerna själva inte ville delta i aktiviteter i största allmänhet utan istället längtade efter meningsfulla aktiviteter där de kände att de kunde bidra med sin kunskap (III). Frankl (1946/2006) menar att den förankring en person har till något eller till någon är central för att känna att livet är meningsfullt och att valen man ställs inför är möjliga att hantera. En metasyntes av elva kvalitativa studier om ensamhet bland äldre personer, visar att en djupare form av ensamhet kan uppkomma av att nära och meningsfulla relationer blir allt färre i takt med högre ålder (Kitzmüller, Clancy, Vaismoradi, Wegener \& Bondas, 2018). Dahlberg, Stolt och Dahlberg (2015) beskriver att ensamhet och gemenskap kan ses som varandras motpoler, men är samtidigt sammanflätade med varandra, och att relationer kan ses som en del av människans existentiella villkor. Enligt Buber $(1962 / 2013)$ är det i våra relationer som vi finns till och existerar. Att vara förankrad till något såsom betydelsefulla ting eller en plats, eller till någon, såsom en vän eller partner handlar om att uppleva ett möte. Buber menar att vi kan ha relation till och uppleva ett möte med: naturen, där relationen är ordlös och inte kan anta språkets form, människor, där relationen är uppenbar och kan anta språkets form samt den andliga världen, där relationen innehåller ett språk av tankar och handlingar. Att lyckas skapa en relationell förankring till något eller någon skulle därmed kunna innebära att ge förutsättningar för möten inte bara med andra människor utan även med naturen och en andlig dimension.

\section{Mötets betydelse}

För att möta en annan person i existentiell ensamhet, i balansgången mellan det som var och det som ska bli och i en längtan efter förankring, har själva mötet och vad som sker i mötet betydelse för att bryta existentiell ensamhet. För att kunna mötas på ett djupare plan behöver man bygga en relation. Ett möte kan skapa en känsla av gemenskap och samhörighet, men ett möte kan också upplevas som tomt och innehållslöst om det har formen av ett "jag" och ett "det", istället för ett "jag" och ett 
"du" (Buber, 1923/2013) eller som Buber uttrycker det: Allt verkligt liv är möte (sid 18 , a.a.).

En del i ett möte handlar om vad det är som är drivkraften, det vill säga varför jag vill (eller inte vill) möta en person. Motivet präglas av sådant som finns med in i ett möte såsom föreställningar om vad som förväntas av närstående eller om hur det är att åldras. Föreställningarna kan te sig olika beroende på var vi befinner oss i livet. Tornstam (1978/2018) menar att det finns tre viktiga delar som präglar de föreställningar som vi har i mötet med andra människor. Föreställningarna formas av kunskap, det vill säga de föreställningar eller vanföreställningar vi har. Denna avhandling visar att det finns diskrepans mellan närståendes uppfattningar och äldre personers upplevelser av existentiell ensamhet (III) som tyder på olika föreställningar om vad som ger mening, samhörighet och frihet. Det handlar om känsla, det vill säga de positiva eller negativa känslor som vi har, samt handling som innefattar den förställning vi har som leder oss till att agera på ett visst sätt (Tornstam, 1978/2018). Vilken roll personen antar kan påverka förställningen om ett möte. Flera närstående (II, III) är söner eller döttrar till en skör äldre far eller mor. Hur närstående tidigare sett på sig själv i relation till sin far eller mor kan påverka möten som sker senare i livet.

I mötet med en annan person behövs lyhördhet såsom att närma sig en annan person i rätt tid (Dahlberg \& Ekman, 2017). Resultaten visar att närstående talade om betydelsen av att få berätta sin historia, sin version, vid upprepade tillfällen (ramberättelse). Det verkar som om det finns ett behov av att få berätta om samma sak vid flera tillfällen, det som ibland i vardagligt språkbruk benämns som att få "älta", det vill säga tid att få berätta och återberätta det man står i, det som har hänt, om sitt liv med någon som lyssnar (I-IV, ramberättelse). En kvalitativ studie om vad som fick sköra äldre personers existentiella ensamhet att lindras eller skingras visar att det är betydelsefullt att känna sig sedd och bekräftad av andra och att känna att andra människor visar omsorg (Sjöberg, Edberg, Rasmussen \& Beck, 2019). Liknande resultat visar den här avhandlingen (ramberättelsen).

\section{Är det möjligt att förstå en annan person?}

En central fråga i ett möte och därmed i denna avhandling är om det är möjligt att förstå en annan person. Kontrasterna som framträder i studie III mellan äldres upplevelser och deras närståendes uppfattningar gör att frågan bör ställas om det är möjligt att någonsin till fullo förstå en annan person - utan att ha egen erfarenhet av en liknande situation. Redan tidigt i designfasen uppstod frågan om vilken insikt de 
närstående hade om de äldre personernas existentiella ensamhet. I studie III kontrasterades därför närståendes uppfattningar mot de äldres upplevelser av existentiell ensamhet. Även om närstående berättade om sina, ofta frekventa, besök hos den äldre personen så upplevde den äldre att livet var tomt och tyst (III) vilket kan förstås som att den äldre inte kände sig mött på djupet. Joan Erikson (1982/1997) beskriver i boken Life cycle completed - extended version, sin sista tid i livet och att hon insåg att det var först då, när hon själv befann sig i den sista fasen av livet, som hon förstod hur andra hade haft det före henne (Erikson, 1982/1997). Samma fynd återfinns i denna avhandling när närstående berättar om sin egen existentiella ensamhet när deras partner antingen förändrats på grund av sjukdom, har flyttat till ett annat boende eller dött. De närstående uttrycker att det är först nu, när de själva är i situationen, som de förstår hur andra har haft det före dem (I).

Resultatet från studie III kan förstås som att närstående och den äldre personen lever sin vardag i olika realiteter och i olika tempo, och kanske därför också hamnar i otakt med varandra och kan ha svårt att riktigt mötas. Sådan kunskap har betydelse i planering av vården som ges till sköra äldre personer och för det stöd som ges till närstående. Det kan vara så att de äldre personerna inte alltid ger närstående eller vårdpersonal tillgång till hela sina berättelser utan endast delger fragment. Då är det inte enkelt att skapa en helhetsbild. En studie av Norell Pejner, Ziegert och Kihlgren (2015) visar att när äldre personer upplevde att något var allt för känslosamt valde de att inte prata med någon i sitt sociala nätverk i första hand, utan valde aktivt att istället samtala med vårdpersonal eftersom de inte ville belasta personer i sin närhet. Det kan också vara så att närstående inte har tillgång till tillräcklig information från hälso- och sjukvårdspersonal för att kunna möta sin familjemedlem med rätt förutsättningar (Andershed \& Ternestedt, 2001). Kristensson Uggla (2014) menar att en person inte endast bär på en berättelse utan snarare på flera som när de berättas för olika personer i olika sammanhang kan anta olika form. Med Jaspers (1971/1995), Kristensson Uggla (2014) och Buber (1923/2008) i åtanke är varje sådan berättelse av betydelse för att förstå helheten, det vill säga närstående eller den äldre personen i sitt sammanhang med sina relationer och behov. Ett äkta möte enligt Buber (1923/2008) handlar om ömsesidighet. Således involverar ett möte både den som möter och den som blir mött. I möten handlar det också om att, som Dahlberg och Ekman (2017) beskriver, erkänna en annan persons behov. Det omfattar inte enbart de synligt uppenbara behoven som kan visa sig som fysiska symtom, utan även de subtila och osynliga, som existentiella behov. 


\section{Personcentrering - ett förhållningssätt}

För att förstå en annan person är ett sätt att handla och tänka utifrån ett personcentrerat förhållningssätt som innebär att: vara personcentrerad (person-centred), vara medveten (being intentional), vara främjande (being facilitative), vara närvarande (being present) (Williams \& McCormack, 2017). Personcentrering använder begreppen "shared decision making" och "shared understanding" (McCormack \& McCance, 2017; Buckley, 2017) som handlar om ömsesidighet och delaktighet som kan uttryckas som: inte $d u$, inte jag utan vi tillsammans. En metasyntes om "shared decision making" visar att det inte är enkelt att få till möten som upplevs som "shared" (delade) (Joseph-Williams, Elwyn \& Edwards, 2014). Ofta nämns kunskap som viktig $\mathrm{i}$ ett möte mellan vårdgivare och mottagare men metasyntesen visar att det inte är tillräckligt för att känna delaktighet. För att ett möte verkligen ska bli ett möte menar forskarna att maktförhållande behöver utjämnas genom att ha liknande uppfattning om situationen och genom att ha tillgång till samma information (a.a.). Kristensson Uggla (2014) beskriver situationen som det trefaldiga underläget som handlar om att personen, i behov av vård, är i ett institutionellt underläge, det vill säga är längst ner i en vårdhierarki, i ett kognitivt underläge, det vill säga är $\mathrm{i}$ ett kunskapsunderläge jämfört med vård- och omsorgspersonal och i ett existentiellt underläge, det vill säga är i en utsatt situation som innebär rädsla och ovisshet. Personcentrering riktar ljuset mot att vara medveten om maktförhållanden och att arbeta för att utjämna makt (McCormack \& McCance, 2017).

Denna avhandling visar att som människor går vi igenom processer i livet som närstående och som äldre där vi utsätts för svåra existentiella val som är knutna till våra nära relationer och att i detta uppstår existentiell ensamhet. Även om Sartre (1947/2007) menar att varje person har ett val, oavsett situation, så berättar närstående att de känner sig tvingade till obekväma, och något som ibland känns som omöjliga, val. Val som de helst vill slippa (I) medan sköra äldre personer upplever att beslut tas åt dem istället för med dem (III). Resultaten visar att sådana val kan göra att människor upplever existentiell ensamhet. Teorin säger att om människan klarar av valen kan hon växa som människa (Yalom, 1980) och lindras i sin existentiella ensamhet. Det fria valet är inte alltid fritt utan beror på hur människan förhåller sig till att stå helt ensam, det vill säga hur vi kan uthärda att vara i existentiell ensamhet. I transitionsprocessen behöver både närstående och äldre stöd för att uthärda existentiell ensamhet. Att bli sedd i sina svåra val är betydelsefullt för att lindra ångest (Sartre, 1947/2007). Med ett personcentrerat förhållningssätt är strävan att stärka personen i att känna tillit till sina val och att främja varje persons möjlighet att själv 
välja (McCormack \& McCance, 2017). Stödet skulle kunna vara att i mötet med äldre personer och närstående, genom berättelser, få dem själva att berätta och på så sätt understödja processerna i de svåra valen.

Vårdpersonal har en viktig roll i mötet med närstående och sköra äldre personer. Studier visar att vårdpersonal upplever att det är utmanande att möta existentiella behov (Sundström, Edberg, Rämgård \& Blomqvist, 2018; Udo, 2014) och att även vårdkontexten har betydelse för hur existentiella behov uppmärksammas (Sundström, Blomqvist, Edberg \& Rämgård, 2019). En möjlighet för att överbrygga utmaningar är kunskap. Det är viktigt att ha kunskap och vara välinformerad för att kunna göra övervägda val, de val man gör för sin egen skull men också de val och de beslut som tas i en annan persons ställe (Andershed \& Ternestedt, 2001). För att överbrygga kunskapsluckor när det gäller stöd till anhöriga i samband med palliativ vård $\mathrm{i}$ hemmet, har en kunskapsöversikt $\mathrm{i}$ en svensk kontext tagits fram av Nka (Hellström, Sandberg, Hanson \& Öhlén, 2017). Kunskapsöversikten kan ses som hjälp och stöd till anhöriga, till professionella och till beslutsfattare. Kunskapsöversikten belyser dock att forskningen i större utsträckning har fokus på vad som ger stöd än hur stödet kan ges, och att stöd till anhöriga fokuserar på praktiska aspekter medan det saknas kunskap om stöd i existentiellt utmanande situationer som vid dödsfall och vid efterlevandesamtal.

Det finns också olika modeller för stöd i mötet med en annan person som i första hand riktar sig till hälso- och sjukvårdspersonal. En sådan är personcentrerad kommunikation som handlar om mötet med samtalet i centrum. Modellen bygger på att närma sig både konkreta behov såsom fysiska symtom men också abstrakta behov som existentiella tankar och att samtalet behöver pendla mellan dessa två olika, men ibland sammanflätade, behov. Modellen inrymmer personen som har behov, personer som finns i närheten samt professionella som ska kunna möta behoven som personen har. Oftast är de konkreta frågorna enklast att samtala om medan de abstrakta hamnar i skymundan (Öhlén, Carlsson, Jepsen, Lindberg \& Friberg, 2015). Att använda en modell att utgå ifrån i ett samtal kan därför vara ett sätt att uppmärksamma såväl konkreta som abstrakta behov och frågor hos närstående, och de personer som finns i deras närhet. Med ett personcentrerat förhållningssätt är en relation där kommunikationen, som kan vara verbal och anta språkets form, viktig men McCormack och McCance (2017) belyser även betydelsen av det ordlösa mötets betydelse, att våga mötas även i tystnaden. I studie IV är det företrädelsevis samtal, enskilda och i grupp, som anhörigkonsulenterna beskriver. Ett stöd i existentiella behov skulle 
kunna innefatta även annat stöd som relaterar till exempelvis natur och andlighet. Denna avhandling visar att ett sådant stöd är betydelsefullt för närstående (ramberättelse).

Avhandlingen visar sammanfattningsvis att mötet med andra människor och de erfarenheter och relationer vi har, är avgörande för hur vi kan förstå och möta våra medmänniskors existentiella ensamhet. Avhandlingen visar också att existentiell ensamhet kan vara svår att uttrycka och möta med ord (jfr Buber 1962/2013). Därför kan mötet med naturen och den andliga dimensionen liksom poesi, musik och litteratur uppmärksammas och användas i större omfattning för att förstå och möta existentiella behov.

«Ord over grind»

Du går fram til mi inste grind

og eg går òg fram til di.

Innanfor den er kvar av oss einsam,

og det skal vi alltid bli.

Aldri trenge seg lenger fram, var lova som gjaldt oss to.

Anten vi møttest titt eller sjeldan var møtet tillit og ro.

Står du der ikkje ein dag eg kjem fell det meg lett å snu når eg har stått litt og sett mot huset og tenkt på at der bur du.

Så lenge eg veit du vil kome iblant som no over knastrande grus og smile glad når du ser meg stå her, skal eg ha ein heim i mitt hus.

Halldis Moren Vesaas 


\section{SLUTSATSER OCH KLINISK BETYDELSE}

- Den här avhandlingen visar att existentiell ensamhet ofta upplevs i övergångsfaser i livet som är kantade av svåra val som i sin tur är knutna till våra nära relationer, $i$ en känsla av meningslöshet och i avsaknad av förankring till något eller någon. Sådan insikt har betydelse i planering och val av stöd i existentiella behov $i$ rätt tid till närstående och till sköra äldre personer. Stödinsatserna bör huvudsakligen vara riktade mot dessa övergångsfaser och fokusera relationella aspekter.

- Avhandlingen visar att det finns skillnader mellan äldre personers upplevelser och närståendes uppfattningar om existentiell ensamhet. Att vara medveten om att dessa skillnader finns har betydelse för den vård och omsorg som planeras och ges.

- Avhandlingen visar att det är viktigt att se en person i sitt sammanhang med sina betydelsefulla relationer och att det är viktigt att lyssna för att försöka förstå en annan persons behov. Oftast finns det flera berättelser som tillsammans kan ge en djupare förståelse än om endast en berättelse blir hörd. Därtill är det angeläget att fundera över vems berättelse som ges tolkningsföreträde $\mathrm{i}$ vård och omsorg. Därför är det viktigt att skapa utrymme för människor att reflektera tillsammans med andra för att höra sina egna och andras tankar och på så sätt kunna sätta ord på sina känslor och upplevelser. 
- Anhörigkonsulenter har en väsentlig roll i mötet och samtalet med närstående till sköra äldre personer. Resultaten visar att de erbjuder närstående samtalsgrupper som närstående också beskriver som viktiga. Men anhörigkonsulenter önskar mer tid och mer kunskap om existentiellt stöd bland annat för att även kunna stödja närstående som förlorat en livskamrat. Att förmedla stöd i upplevelsen av existentiell ensamhet har betydelse för närståendes och sköra äldre personers existentiella välbefinnande. 


\section{FORTSATT FORSKNING}

Det är troligt att i takt med en åldrande befolkning blir allt fler närstående i anspråkstagna för att hjälpa och stödja sköra äldre personer i sin närhet. För att kunna vara ett stöd för en annan person är det viktigt att själv få både stöd och kunskap. Vi behöver mer kunskap om hur existentiellt stöd för närstående skulle kunna vara utformat och fungera. Avhandlingen visar att berättelsen är central både för närstående och för sköra äldre personer. Att utveckla fler forum där berättelserna får vara i centrum kan vara ett sätt att ge existentiellt stöd. Att fă mötas i andra samtalsformer än genom mötet där språket är centralt, som genom musik, litteratur och konst, kan vara andra former. Anhörigkonsulenter är en tillgång och en resurs men uppdraget ser olika ut i olika kommuner. Vi behöver fördjupad kunskap om deras erfarenheter av stöd till närstående i existentiella frågor och hur efterlevandestöd skulle kunna utvecklas. Existentiell ensamhet är sammanflätad med andra former av ensamhet men även med andra tillstånd som depression eller ångest. Det behövs mer kunskap om överlappningar mellan dessa tillstånd. Det är också angeläget med mer kunskap om existentiell ensamhet $i$ andra delar av livet som tonårstid eller som nybliven förälder vilket är skeden som innebär övergångsfaser i livet. 


\title{
SUMMARY IN ENGLISH
}

\author{
Existential loneliness among frail older people \\ from the perspective of significant others
}

\section{Background}

Existential loneliness is described as a deeper feeling of loneliness, as intertwined with other forms of loneliness and as a human condition. However, there are few empirical studies and knowledge is scarce regarding how this form of loneliness is expressed and communicated. To be ageing and becoming frail due to physical impairments can be seen as a time in life that involves existential thoughts, where existential loneliness can be one such thought. It is likely that at such times, significant others become increasingly important for the older person. However, in order to be supportive, it is important that significant others get the support they need. Therefore, every municipality in Sweden has an obligation to support significant others who help someone else, often through a family care advisor. In order to gain a deeper understanding of existential loneliness, it is important to explore different actors' experiences and perceptions, contrasts between them, and what existential support is required and provided.

\section{Aims}

The overall aim of this thesis was to explore existential loneliness from the perspective of significant others, to contrast their perceptions with the experiences of frail older people and to describe significant others' and family care advisors' views on existential support. The specific aims were to: I) explore spouses' existential loneliness when caring for a frail partner late in life, II) explore frail older people's existential loneliness, as interpreted by their significant others, III) contrast frail older people's experiences with their significant others' perceptions of existential loneli- 
ness, and IV) investigate the family care advisors' views on existential loneliness, and of the existential support provided to those who care for older relatives.

\section{Methods}

This thesis is part of a larger research project about existential loneliness among frail older people, the LONE study, and focuses on the perspective of significant others. The significant others were husbands, wives, daughters, sons, other relatives and friends to frail older people. The concept 'frail older people' was defined as older persons ( $\geq 75$ years old) dependent on long-term health- or social care. The care was provided by primary health care, municipal home care, residential care, hospital and specialized palliative care. The family care advisors worked in one of Sweden's 290 municipalities.

The thesis includes three qualitative and one quantitative study. A total of 29 significant others, 15 frail older people and 120 family care advisors participated in the studies. The qualitative studies were based on multistage focus-group interviews (study I) with significant others, and individual interviews (studies II and III) with significant others and older people. The quantitative study (IV) had a cross-sectional design and was based on a questionnaire specifically developed to examine family care advisors' views. Different methods of analysing data were used: hermeneutics to interpret significant others' own experiences of existential loneliness (study I), content analysis to analyse their perceptions (study II) and a case study with thematic analysis to contrast experiences and perceptions of existential loneliness (study III). The questionnaire was analysed using descriptive statistics, processed in SPSS (study IV).

\section{Findings}

Findings from the four studies show that existential loneliness emerges when: 1) Longing for, but also striving for, a deeper feeling of connectedness, 2) Being in, but also enduring an unwanted separation, and 3) Not finding, but still trying to recreate meaning. When significant others who were husbands and wives talked about their own experiences of existential loneliness they referred to moments of inner struggle, when they felt forced to make impossible choices for their partner rather than together with him/her, when they felt like they were navigating an unfamiliar situation and questioned themselves, and when they experienced the endless loss of the other (study I). When significant others instead talked about their perceptions of older people's existential loneliness, they referred to how the older person became in- 
creasingly limited in body and space, which, in turn, made them dependent on others and restricted their freedom. Significant others also referred to how they noticed that the older people were in a process of disconnecting from families and friends and becoming increasingly disconnected from the outside world (study II). When older people's experiences were contrasted with their significant others' perceptions of existential loneliness, the findings showed that the older people experienced existential loneliness in meaningless waiting, though significant others tried to engage them in activities. The older people longed for a deeper connectedness, though significant others tried to encourage them to participate in a social environment, and the older people experienced existential loneliness as a restricted freedom, though the significant others perceived that the older person had given up on life (study III). The family care advisors provided existential support mainly by talking to and by visiting significant others. They also provided contact to organized discussion groups. A total of 45 percent reported that they had time in their work to provide existential support and 27 percent reported that they had necessary skills for supporting those with existential loneliness (study IV).

\section{Discussion}

This thesis shows that existential loneliness is often experienced in so-called limit situations in life. Existential loneliness arises in difficult choices related to close relationships, in connection with experiences of meaninglessness and in the absence of connection to something or someone. The results show that existential loneliness emerges in the process of balancing between what was and what is to come in the unknown future. Significant others navigate themselves, and sometimes together with the older person, through an unfamiliar existence that makes them feel ambivalent about the decisions they have made and the decisions they need to make in the future, while also doubting the meaning in their current situation (study I). Further, existential loneliness seems to emerge in a longing for a deeper connectedness. The results show that significant others perceive that existential loneliness emerges in older people's lives as life becomes increasingly empty - when former friends or relatives have died, when cherished material belongings have been dispersed or when illness and disability have forced the older person to move away from their home (study II). Existential support should mainly focus on transition phases in significant others' lives and focus on relational aspects. The thesis shows that it is important to see people in their context with their important relationships and that it is essential to listen to and try to understand the other person's needs. However, a central question in this thesis is whether it is possible to understand another person. The 
results show differences between older people's experiences and significant others' perceptions of existential loneliness (study III). It is important that health care professionals and researchers listen to both frail older people and their significant other(s) and are aware of whose voice is given priority. The results show that family care advisors may lack skills and time to work with existential needs and existential loneliness. To have the necessary time and knowledge are important prerequisites for embracing a holistic view that includes acknowledging people's physical, social, emotional and existential needs. Person-centredness can be a way to make the existential needs of significant others and older people visible and to provide support based on those needs.

\section{Conclusions, clinical implications and future research}

We need more knowledge about how existential support for significant others can be designed and organized. This thesis shows that it is important to create space for people to reflect together with others in order to hear their own and others' thoughts, and thus be able to put feelings and experiences into words. Organizing forums where narrations are at the centre can be a way to provide existential support. Music, literature and art can be other ways to provide existential support. Family care advisors are an asset and a resource, but their assignments differ. We need in-depth knowledge of their experiences of supporting significant others in existential issues. Existential loneliness is intertwined with other forms of loneliness but also with other conditions such as depression or anxiety. More knowledge about overlaps between these conditions is needed. There is also a need for deeper understanding about existential loneliness in limit situations in life, such as during adolescence or becoming a new parent. 


\section{TACK}

Tack alla närstående och äldre personer för att ni har delat med er av era erfarenheter. Tack för att ni tog er tid och för att jag fick ta del av era berättelser. Ni är alla en del av denna avhandling. Tack också till anhörigkonsulenter runt om i landet för att ni tog er tid att besvara enkäten. Ett särskilt tack vill jag rikta till Gunilla Andersson, Stina Lindén och Anita Strömberg för all er hjälp.

Tack referensgruppen för LONE-studien - Ann-Magreth Albin, Bengt Gustafsson, Mogens Hey, Lisbeth Mattsson, Anita Olsson och Eva Wiman. Tack för ert stöd och er uppmuntran under de här åren. Tack för att ni har lyssnat till vad jag kom fram till, för era kloka synpunkter och frågor.

Tack till mina handledare. Jag har haft förmånen att ha goda förebilder vid min sida som har lotsat mig steg för steg genom studierna. Tack professor Ingrid Bolmsjö, min första huvudhandledare, för att du introducerade mig i Malmö på ett inkännande och fint sätt. Du visade mig in i ett filosofiskt landskap av litteratur och du brydde dig om mig, frågade om min familj och önskade alltid att jag skulle komma gott hem. Jag är glad att jag fick möta dig och ta del av din erfarenhet. Tack min nästa huvudhandledare professor Christine Kumlien. Tack för att du tog på dig ansvaret att vara huvudhandledare när Ingrid gick i pension. Tack för att du inte tog över utan tog vid. Tack för din lyhördhet och för att du har lotsat mig in i de kvantitativa begreppens värld. Tack universitetslektor Margareta Rämgård för att du har varit min biträdande handledare. Tack för att du hela tiden har utmanat min tanke och mina förgivettagna perspektiv. Du har gett mig många nya insikter. Tack professor AnnaKarin Edberg för att du har varit min biträdande handledare, för din klokskap och uppmuntran. Tack för att du flera gånger har sagt "Lysande", fastän du säkert tänkt "Ja, i alla fall ganska lysande", men då du säkert förstått att jag har behövt höra ly- 
sande först för att kunna ta till mig fortsättningen. Tack professor Kerstin Blomqvist för att du har varit min biträdande handledare. Tack för skratt och för påminnelser om att det mesta i livet är viktigare än doktorandstudier. Tack för att du har tagit hål på allvaret utan att förminska en enda studies eller tankes betydelse. Tack för allt som du har lärt och lär mig och för att du vill gå bredvid mig och handfast visa hur man kan göra.

Tack seminarieledare vid Malmö universitet och vid Högskolan Kristianstad Christine Kumlien och Elisabeth Carlson, Anna-Karin Edberg, Albert Westergren och Kerstin Blomqvist. Tack doktorandkollegor för givande, inspirerande och stöttande diskussioner och samtal. Jag kommer att sakna våra samtal. Hoppas att våra vägar möts igen på olika sätt framöver. Särskilt tack till Malin Sundström och Marina Sjöberg för vad jag har fått uppleva tillsammans med er i LONE-studien och utanför. "En för alla, alla för en".

Tack Marina Sjöberg och Ingela Beck för att jag fick använda era intervjuer och fältanteckningar till studie III. Tack Magdalena Andersson för hjälp med intervjuer inledningsvis av mina doktorandstudier.

Tack till forskargruppen i LONE-studien för värdefulla diskussioner, stöd och uppmuntran - Anna-Karin Edberg, Ingrid Bolmsjö, Margareta Rämgård, Kerstin Blomqvist, Ingela Beck, Christine Kumlien, Birgit Rasmussen, Ingalill Rahm Hallberg, Marina Sjöberg, Malin Sundström och Jonas Olofsson. Tack också till Magdalena Andersson som var med i projektets inledande fas.

Tack till finansiärerna som gjort studierna möjliga: Crafoordska stiftelsen, Greta och Johan Kocks stiftelse, Gyllenstiernska Krapperupsstiftelsen, Vårdalstiftelsen, Forskningsplattformen Hälsa i samverkan vid Högskolan Kristianstad samt Malmö universitet och Högskolan Kristianstad.

Tack till er som på olika sätt har hjälpt mig med språket genom studierna och i ramberättelsen - Daniel Borg, Katarina Graah-Hagelbäck, Samuel Larsson, Tobias Månsson och Cecilia Sahlström. Tack Mattias Larsson för det vackra fotot till omslaget. 
Tack till mina föräldrar, Margareta och Johnny Lindfors, till mina svärföräldrar, Lillemor och Nils Larsson, för hjälp och uppmuntran. Tack vänner och syskon, svägerskor och svågrar. Ni gör livet roligt. Tack för sångstunder, promenader, arbetskvällar, semestrar, kalasfix, bergsbestigning, skidåkning, skogsturer, läger och mycket mer.

Till sist vill jag tacka min tålmodiga familj. Tack till min man Henrik - min livskamrat och hjälpare i allt. Tack för att du gav mig möjligheten att göra detta. Tack till våra barn - Viktor, Ebba och Vera. Tack för att ni finns, är så fina och hjälpsamma. Ni är älskade, alltid. 


\section{REFERENSER}

Abrahamsson, K., Bernard, B., Magnabosco, L., Nazir, A., \& Unroe, K.T. (2016). The experiences of family members in the nursing home to hospital transfer decision. BMC Geriatrics, 16, 184.

Andershed, B. (2006). Relatives in end-of-life care part 1: a systematic review of the literature the five last years, January 1999-February 2004. Journal of Clinical Nursing, 15(9), 1158-1169.

Andershed, B., \& Ternestedt, B-M. (2001). Development of a theoretical framework describing relatives' involvement in palliative care. Journal of Advanced Nursing, 34(4), 554-562.

Andersson, M., Ekwall, A-K., Hallberg, I.R., \& Edberg, A-K. (2010). The experience of being next of kin to an older person in the last phase of life. Journal of Palliative and Supportive Care, 8, 17-26.

Anker-Hansen, C., Skovdahl, K., McCormack, B., \& Tønnessen, S. (2018). The third person in the room: The needs of care partners of older people in home care services - A systematic review from a person-centred perspective. Journal of Clinical Nursing, 27(7-8), 1309-1326.

Applebaum, F. (1978). Loneliness: a taxonomy and psychodynamic view. Clinical Social Work Journal, 6(1).

Beauchamp, T., \& Childress, J. (2013). Principles of Biomedical Ethics. Oxford: University Press.

Bergum, V., \& Dossetor, J. (2005). Relational Ethics: the full Meaning of Respect. Hagerstown: University Publishing Group.

Boise, L., \& White, D. (2004). The family's role in person-centered care. Practice considerations. Journal of Psychosocial Nursing and Mental Health Services, 42(5), 12-20.

Bollig, G., Gjengedal, E., \& Rosland, J.H. (2015). They know! -Do they? A Qualitative study of residents and relatives views on advance care planning, end-of-life care, and decision-making in nursing homes. Palliative Medicine, 30(5), 456-470.

Bolmsjö, I., \& Hermerén, G. (2001). Interviews with patients, family and caregivers in amyotrophic lateral sclerosis: comparing needs. Journal of Palliative Care, 17(4), 236-240.

Bolmsjö, I., Tengland, P-A., \& Rämgård, M. (2018). Existential Loneliness: An attempt at an analysis of the concept and the phenomenon. Nursing Ethics, 1-16.

Braun, V., \& Clarke, V. (2006). Using thematic analysis in psychology. Qualitative Research in Psychology, 3(2), 77-101. 
Broström, M. (2014). Äldre människors föreställningar om den egna framtiden, döendet och döden. Linköpings universitet: Akademisk avhandling.

Buber, M. (1923/2013). Jag och Du. Ludvika: Dualis.

Buber, M. (1923/2008). Dialogens Väsen. Ludvika: Dualis.

Buckley, C. (2017). i red: McCormack, B., \& McCance, T. Nursing and Health Care. Theory and Practice. 2 uppl. UK: Wiley.

Caspari, S., Lohne, V., Rehnsfeldt, A.W., Saeteren, B., Slettebö, Å., Heggestad, A.K.T., Lillestö, B., Höy, B., Råholm, M-B., Lindwall, L., Aasgaard, T., \& Nåden, D. (2014). Dignity and existential concerns among nursing homes residents from the perspective of their relatives. Clinical Nursing Studies, 2(3).

Dahlberg, K. (2007). The enigmatic phenomenon of loneliness. International Journal of Qualitative Studies on Health and Well-being, 2(4), 195-207.

Dahlberg, K., Dahlberg, H., \& Nyström, M. (2008). Reflective Lifeworld Research. Lund: Studentlitteratur.

Dahlberg, K., \& Ekman, I. (2017). Att lyssna på och förstå patienters berättelser - några teoretiska utgångspunkter. i red: Dahlberg, K., \& Ekman, I. Vägen till patientens värld och personcentrerad vård. Att bli lyssnad på och förstådd. Stockholm: Liber.

Dahlberg, K., Stolt, C.M., \& Dahlberg, H. (2015). Ensamheter. En utforskande brevväxling. Stockholm: Liber.

Denscombe, M. (2009). Item non-response rates: a comparison of online and paper questionnaires. International Journal of Social Research Methodology, 12(4), 281-291.

Dewing, J., Eide, T., \& McCormack, B. (2017). i red: McCormack, B., van Dulmen, S., Eide, H., Skovdahl, K., \& Eide, T. Person-Centred Healthcare Research. UK: Wiley.

Dyrstad, D.N., Laugaland, K.A., \& Storm, M. (2015). An observational study of older patients' participation in hospital admission and discharge - exploring patient and next of kin perspectives. Journal of Clinical Nursing, 24(11-12), 1693-1706.

Edberg, A-K., \& Bolmsjö, I. (2019). Exploring existential loneliness among frail older people as a basis for an intervention: Study protocol of the development phase of the LONE study. RR210.2196/1307, JMIR Research Protocols, doi:10.2196/13607.

Edvardsson, D., Sandman, P.O., \& Rasmussen, B. (2006). Caring or uncaring - meanings of being in an oncology environment. Journal of Advanced Nursing, 55(2), 188-197.

Eika, M., Espnes, G.A., Söderhamn, O., \& Hvalvik, S. (2014). Experiences faced by next of kin during their older family members' transition into long-term care in Norwegian nursing home. Journal of Clinical Nursing, 23, 2186-2195.

Erikson, E.H. (1982/1997). The life cycle completed. Extended version with new chapters on the ninth stage of development by Joan M. Erikson. New York: Norton \& Company.

Eriksson, H., Sandberg, J., \& Hellström, I. (2012). Experiences of long-term care as an informal caregiver to a spouse: gendered in everyday life for female carers. International Journal of Older People Nursing, 8(2), 159-165. 
Erlingsson, C.L., Magnusson, L., \& Hanson, E. (2012). Family caregivers' health in connection with providing care. Qualitative Health Research, 22(5), 640-655.

Ettema, E.J., Derksen, L.D., \& van Leeuwen, E. (2010). Existential loneliness and end-of-life care: A systematic review. Theoretical Medicine and Bioethics, 31, 141-169.

Fillit, H., \& Butler, R. (2009). The frailty identity crisis. Journal of the American Geriatrics Society, 57, 348-352.

Frankl, V. (1946/2006). Livet måste ha en mening. Stockholm: Natur \& Kultur.

Funck, L., Stajduhar, K.I., Toye, C., Aoun, S., Grande, G.E., \& Todd, C.J. (2010). Part 2: Homebased family caregiving at the end of life: A comprehensive review of published qualitative research (1998-2008). Palliative Medicine, 24(6), 594-607.

Førsund, L.H., Skovdahl, K., Kiik, R., \& Ytrehus, S. (2015). The loss of a shared lifetime: a qualitative study exploring spouses' experiences of losing couplehood with their partner with dementia living in institutional care. Journal of Clinical Nursing, 24(1-2), 121-130.

Gadamer, G-H. (1960/1990). Sanning och metod. Göteborg: Daidalos.

Gee, J.P. (1985). The Narrativization of experience in the oral style. The Journal of Education, 167(1), 9-35.

Gee, J.P. (1991). A Linguistic approach to narrative. Journal of Narrative and Life History, 1(1), 15-39.

Goodridge, D., Isinger, T., \& Rotter, T. (2018). Patient family advisors' perspectives on engagement in health-care quality improvement initiatives: Power and partnership. Health Expectations, 21, 379-386.

Graneheim, U.H., \& Lundman, B. (2010). Experiences of loneliness among the very old: the Umeå 85+ project. Aging \& Mental Health, 14(4), 433-438.

Greenwood, N., \& Smith, R. (2015). Barriers and facilitators for male carers in accessing formal and informal support: A systematic review. Maturitas, 82, 162-169.

Greenwood, N., \& Smith, R. (2016). The oldest carers: A narrative review and synthesis of the experiences of carers aged over 75 years. Maturitas, 94, 161-172.

Guba, E. (1981). Annual Review Paper: Criteria for assessing the trustworthiness of naturalistic inquiries. Educational Communication and Technology, 29(2), 75-91.

Hellström, I., Sandberg, J., Hanson, E., \& Öhlén, J. (2017). Nka. Stöd till anhöriga i samband med palliativ vård $i$ hemmet: en kunskapsöversikt. 2017:1. Hämtad oktober 2019 från www.anhoriga.se

Hogsnes, L., Melin-Johansson, C., Norbergh, K.G., \& Danielsson, E. (2014). The existential life situations of spouses of persons with dementia before and after relocating to a nursing home. Aging \& Mental Health, 18(2), 152-160.

Hombres, E., Schnepf, S., Barjakova, M., \& Teixeira Mendonca, F. (2018). Loneliness - an unequally shared burden in Europe. EU, European Commission. Policy Brief. Hämtad januari 2020 från https://ec.europa.eu/jrc/sites/jrcsh/files/fairness pb2018 loneliness jrc i1.pdf 
Hsieh, H.F., \& Shannon, S.E. (2005). Three approaches to qualitative content analysis. Qualitative Health Research, 15(9), 1277-1288.

HSL, Hälso- och sjukvårdslagen. 2017:30. Svensk författningssamling.

Hummelvoll, J.K. (2008). The multistage focus group interview. Norsk Tidskrift for Sykepleieforskning, 10(1), 3-14.

Irving, J. (2015). Beyond family satisfaction: Family-perceived involvement in residential care. Australasian Journal of Ageing, 34(3), 166-170.

Jacobs, G., van Lieshout, F., Borg, M., \& Ness, O. (2017). i red: McCormack, B., van Dulmen, S., Eide, H., Skovdahl, K., \& Eide, T. Person-Centred Healthcare Research. UK: Wiley.

Jakobsson, U. (2011). Forskningens termer \& begrepp. En ordbok. Lund: Studentlitteratur.

James, I., Andershed, B., \& Ternestedt, B-M. (2009). The encounter between informal and professional care at the end of life. Qualitative Health Research, 19(2), 258-271.

Jaspers, K. (1971/1995). Philosophy of Existence. Philadelphia: University of Pennsylvania Press.

Johansson, L., Long, H., \& Parker, M.G. (2011). Informal caregiving for elders in Sweden: An analysis of current policy development. Journal of Aging \& Social Policy, 23(4), 335-353.

Joseph-Williams, N., Elwyn, G., \& Edwards, A. (2014). Knowledge is not power for patients: A systematic review and thematic synthesis of patient-reported barriers and facilitators to shared decision making. Patient Education and Counseling, 94, 291-309.

Kierkegaard, S. (1844/1997). Filosofiska smulor. Hörby: Nimrod.

Kitzmüller, G., Clancy, A., Vaismoradi, M., Wegener, C., \& Bondas, T. (2018). "Trapped in an empty waiting room" - The existential human core of loneliness in old age: A meta-synthesis. Qualitative Health Research, 28(2), 213-230.

Koplow, S.M., Gallo, A.M., Knafl, K.A., Vincent, C., Paun, O., \& Gruss, V. (2015). Family caregivers define and manage the nursing home placement process. Journal of Family Nursing, 21(3), 469-493.

Kristensson Ekwall, A., \& Rahm Hallberg, I. (2007). The associations between caregiving satisfaction, difficulties and coping among older family caregivers. Journal of Clinical Nursing, $16(5), 832-844$.

Kristensson Uggla, B. (2014). Personfilosofi - filosofiska utgångspunkter för personcentrering inom hälso- och sjukvård. i red: Ekman, I. Personcentrering inom hälso- och sjukvård. Från filosofi till praktik. Stockholm: Liber.

Kristensson Uggla, B. (2019). En strävan efter sanning. Vetenskapens teori och praktik. Lund: Studentlitteratur.

Krueger, R., \& Casey, M. (2015). Focus Groups. A Practical Guide for Applied Research. 5:e uppl. Thousand Oaks: Sage.

Lukas, A., Niederecker, T., Günther, I., Mayer, B., \& Nikolaus, T. (2013). Self- and proxy report for the assessment of pain in patients with and without cognitive impairment: experience gained in a geriatric hospital. Zeitschrift für Gerontologie und Geriatrie, 46, 214-221.

Magnusson, F. (2014). Reshaping eldercare towards new profession. Social Work, 13(2), 179-191. 
Mansfield, L., Daykin, N., Meads, C., Tomlinson, A., Gray, K., Lane, J., \& Victor, C. (2019). A conceptual review of loneliness across the adult life course (16+years). UK: What Works Centre for Wellbeing.

Mayers, A.M., \& Svartberg, M. (2001). Existential loneliness: A review of the concept, its psychosocial precipitants and psychotherapeutic implications for HIV-infected women. British Journal of Medical Psychology, 74, 539-553.

McCormack, B. (2004). Person-centredness in gerontological nursing: an overview of the literature. International Journal of Older People Nursing, 13, 31-38.

McCormack, B., \& McCance, T. (2017). i red: McCormack, B., \& McCance, T. Person-Centred Practice in Nursing and Health Care. Theory and Practice. 2:a uppl. UK: Wiley.

Melder, C. (2011) Vilsenhetens epidemiologi, en religionspsykologisk studie i existentiell folkhälsa. Uppsala universitet: Akademisk avhandling.

Melin-Johansson, C., Henoch, I., Strang, S., \& Browall, M. (2012). Living in the presence of death: an integrative literature review of relatives' important existential concerns when caring for a severely ill family member. The Open Nursing Journal, 6, 1-12.

Moustakas, C.E. (1961). Loneliness. New York: Prentice-Hall.

MRC, Medical Research Council (2008). Developing and Evaluating Complex Interventions: New Guidance. London: Medical Research Council.

Neri, A., Yassuda, M.S., Fortes-Burgos, A.C.G., Mantovani, E.P., Arbex, F.S., Torres, S.V., Perracini, M.R., \& Guariento, M.E. (2012). Relationships between gender, age, family, conditions, physical and mental health, and social isolation of elderly caregivers. International Psychogeriatrics, 24(3), 472-483.

Norell Pejner, M., Ziegert, K., \& Kihlgren, A. (2015). Older patients' in Sweden and their experience of the emotional support received from the registered nurse - a grounded theory study. Aging \& Mental Health, 19(1), 79-85.

Nyqvist, F., Victor, C., Forsman, A.K., \& Cattan, M. (2016). The association between social capital and loneliness in different age groups: a population-based study in western Finland. $B M C$ Public Health, 16, 542.

Nyström, M. (2006). Aphasia - an existential loneliness: A study on the loss of the world of symbols. International Journal of Qualitative Studies on Health and Well-being, 1, 38-49.

Oh, Y., \& Han, E. (2019). Review of studies on spousal caregivers of frail spouses in South Korea. International Social Work, 62(2), 529-548.

Perlman, D., \& Peplau, L.A. (1998). Loneliness. Encyclopedia of Mental Health, 2, 571-581.

Pinel, E., Long, A.E., Murdoch, E.Q., \& Helm, P. (2017). A prisoner of one's own mind: Identifying and understanding existential isolation. Personality and Individual Differences, 105, 54-63.

Plöthner, M., Schmidt, K., de Jong, L., Zeidler, J., \& Damm, K. (2019). Needs and preferences of informal caregivers regarding outpatient care for the elderly: a systematic literature review. BMC Geriatrics, 19(82). 
Polit, D.F., \& Beck, C.H. (2017). Nursing Research. Generating and Assessing Evidence for Nursing Practice. 10:e uppl. Philadelphia: Wolters Kluwer.

Pozzebon, M., Douglas, J., \& Ames, D. (2016). Spouses' experience of living with a partner diagnosed with a dementia: a synthesis of the qualitative research. International Psychogeriatrics, 2(4), 537-556.

Ris, I., Schnepp, W., \& Imhof, M.R. (2019). An integrative review on family caregivers' involvement in care of home-dwelling elderly. Health and Social Care, 27, e95-111.

Robertson, S., Cooper, C., Hoe, J., Hamilton, O., Stringer, A., \& Livingston, G. (2017). Proxy rated quality of life of care home residents with dementia: a systematic review. International Psychogeriatrics, 29, 569-581.

Rogers, C.R. (1969/2003). On becoming a person. London: Robinson Publishing.

Russel, H., \& Foreman, P.E. (2002). Maintaining a relationship with family member in a nursing home: The role of visitor. Journal of Family Studies, 8, 147-164.

Rämgård, M., \& Nieminen Kristofersson, T. (2010). "Låt inte spindelväven växa i ditt hjärta” En forskningscirkel om poesins verkan för sjuksköterskor i palliativ vård. FoU Skåne Skriftserie 2010:3.

Sand, L., \& Strang, P. (2006). Existential loneliness in a palliative home care setting. Journal of Palliative Medicine, 9(6).

Sand, L., \& Strang, P. (2013). När döden utmanar livet. Om existentiell kris och coping i palliativ vård. Stockholm: Natur \& Kultur.

Sandberg, J., Lundh, U., \& Nolan, M. (2002). Moving into a care home: the role of adult children in the placement process. International Journal of Nursing Studies, 39, 353-362.

Sandberg, J., \& Eriksson, H. (2007). 'The hard thing is the changes' The importance of continuity for older men caring for their wives. Quality in Ageing policy, practice and research, 8(2), 515.

Sartre, J.P. (1947/2007). Existentialism is a humanism. London: Yale University press.

SCB, Statistiska Centralbyrån. Befolkningsstatistik 2018. Hämtad augusti 2019 från www.scb.se

Schuster, M. (2006). Profession och Existens: En hermeneutisk studie av asymmetri och ömsesidighet i sjuksköterskors möten med svårt sjuka patienter. Göteborg: Daidalos.

Shenton, A. (2004). Strategies for ensuring trustworthiness in qualitative research projects. Education for Information, 22, 63-75.

Silva, A.L., Teixeira, H.J., Teixeira, M.J., \& Freitas, S. (2013). The needs of informal caregivers of elderly people living at home: an integrative review. Scandinavian Journal of Caring Sciences, 27(4), 792-803.

Sjöberg, M., Beck, I., Rasmussen, B.H., \& Edberg, A-K. (2018). Being disconnected from life: Meanings of existential loneliness as narrated by frail older people. Aging \& Mental Health, $22(10), 1357-1364$. 
Sjöberg, M., Edberg, A-K., Rasmussen, B.H., \& Beck, I. (2019). Being acknowledged by others and bracketing negative thoughts and feelings: Frail older people's narrations of how existential loneliness is eased. International Journal of Older People Nursing, 14(1), e12213.

Smith, J. (2012). Loneliness in older adults: An embodied experience. Journal of Gerontological Nursing, 38(8), 45-53.

Socialstyrelsen, (2012). Anhöriga som ger omsorg till närstående - omfattning och konsekvenser. Hämtad oktober 2019 från www.socialstyrelsen.se

Socialstyrelsen, (2019a). Vård och omsorg om äldre. Lägesrapport. Hämtad oktober 2019 från www.socialstyrelsen.se

Socialstyrelsen, (2019b). Vad tycker de äldre om äldreomsorgen? Hämtad oktober 2019 från www.socialstyrelsen.se

Socialstyrelsens termbank, (2019). Anhörig, Närstående. Hämtad oktober 2019 från www.termbank.socialstyrelsen.se

SoL, Socialtjänstlagen 2001:453, 5:10. Hämtad oktober 2019 från www.riksdagen.se

Stokols, D. (1975). Toward a psychological theory of alienation. Psychological Review, 82, 26-44.

Stoltz, P., Udén, G., \& Willman, A. (2004). Support for family carers who care for an elderly person at home - a systematic literature review. Scandinavian Journal of Caring Sciences, 18(2), 111-119.

Stoltz, P., Willman, A., \& Udén, G. (2006). The meaning of support as narrated by family carers who care for a senior relative at home. Qualitative Health Research, 16(5), 594-610.

Stow, D., Spiers, G., Matthews, F.E., \& Hanratty, B. (2019). What is the evidence that people with frailty have needs for palliative care at the end of life? A systematic review and narrative synthesis. Palliative Medicine, 33(4), 399-414.

Strang, P. (2014). Att höra till - om ensamhet och gemenskap. Stockholm: Natur \& Kultur.

Streiner, D.L., \& Norman, G.R. (2008). Health Measurements Scales - a practical guide to their development and use. 4:e uppl. USA: Oxford University Press.

Sundström, M., Edberg, A-K., Rämgård, M., \& Blomqvist, K. (2018). Encountering existential loneliness among older people: perspectives of health care professionals. International Journal of Qualitative Studies in Health Well-being, 13(1), 1474673.

Sundström, M., Blomqvist, K., Edberg, A-K., \& Rämgård, M. (2019). The context of care matters: Older people's existential loneliness from the perspective of healthcare professionals - A multiple case study. International Journal of Older People Nursing, 14(3), e12234.

Søvde, B.E., Hovland, G., Ullebust, B., \& Råholm, M.J. (2019). Struggling for a dignifying care: experiences of being next of kin to patients in home health care. Scandinavian Journal of Caring Sciences, 33(2), 409-416.

Sønderby, L.C., \& Wagoner, B. (2013). Loneliness: An integrative approach. Journal of Integrated Social Sciences, 3(1), 1-29.

Taube, E., Jakobsson, U., Midlöv, P., \& Kristensson, J. (2016). Being in a bubble: The experience of loneliness among frail older people. Journal of Advanced Nursing, 72(3), 631-640. 
Tengland, P-A. (2008). Empowerment: A Conceptual Discussion. Health Care Analysis, 16(2), 77-96.

Thomson, H. (2010). Reflexiva intervjuer. Lund: Studentlitteratur.

Thornquist, E. (2012). i red: Kalman, H., \& Lövgren, V. Etiska dilemman. Forskningsdeltagande, samtycke och utsatthet. Malmö: Gleerups.

Tornstam, L. (1978/2018). Aldrandets socialpsykologi. 9:e uppl. Lund: Studentlitteratur.

Udo, C. (2014). The concept and relevance of existential issues in nursing. European Journal of Oncology Nursing, 18, 347-54.

van Wijngaarden, E., Leget, C., \& Goossensen, A. (2015). Ready to give up on life: The lived experience of elderly people who feel life is completed and no longer worth living. Social Science \& Medicine, 138, 257-264.

Vetenskapsrådet (2011). God forskningssed. Vetenskapsrådets rapportserie 2011:1.

Wallerstedt, B., Behm, L., Alftberg, Å., Sandgren, A., Benzein, E., Nilsen, P., \& Ahlström, G. (2018). Striking a balance: A qualitative study of next of kin participation in the care of older persons in nursing homes in Sweden. Healthcare, 6(46), doi:10.3390/healthcare6020046

Weiss, R.S. (1987). Reflections on the present state of loneliness research. Journal of Social Behavior \& Personality, 2(2), 1-16.

Wenemark, M. (2017). Enkätmetodik. Med respondenten i fokus. Lund: Studentlitteratur.

Wester, A., Larsson, L., Olofsson, L., \& Pennbrant, S. (2013). Caregivers' experiences of caring for an elderly next of kin in Sweden. Vård i Norden, 4(33), 28-32.

Whitaker, A. (2009). Family involvement in the institutional eldercare context. Towards a new understanding. Journal of Aging Studies, 23, 158-167.

WHO, (2019). World Health Organization. Hämtad december 2019 från www.who.int/

Williams, C., \& McCormack, B. (2017). i red. McCormack, B., van Dulmen, S., Eide, H., Skovdahl, K., \& Eide, T. Person-Centred Healthcare Research. UK: Wiley.

Winqvist, M. (2014). Nka. Anhörigkonsulentens arbete och yrkesroll - Resultat från en enkätundersökning. Rapport 2014:1.

Winqvist, M., Magnusson, L., Beijer, U., Göransson, S., Takter, M., Tomazic, D., \& Hanson, E. (2016). Nka. Stöd till anhöriga. Erfarenheter från åtta kommuner 2010-2013. Slutrapport. Rapport 2016:2.

Winqvist, M. (2016). Nka. Individualisering, utvärdering och utveckling av anhörigstöd. Rapport 2016:4

WMA, (2013). World Medical Association. Declaration of Helsinki: Ethical principles for medical research involving human subjects. Hämtad december 2019 från www.wma.net/policiespost/wma-declaration-of-helsinki-ethical-principles-for-medical-research-involving-humansubjects/

Yalom, I.D. (1980). Existential psychotherapy. New York: Basic Books.

Yin, R.K. (2009). Case Study Research - Design and Methods. 4:e uppl. Thousand Oaks: Sage. 
Öhlén, J., Carlsson, G., Jepsen, A., Lindberg, I., \& Friberg, F. (2015). Enabling sense-making for patients receiving outpatient palliative treatment: A participatory action research driven model for person-centered communication. Palliative \& Supportive Care, 14(3), 212-224. 


\section{APPENDIX I. [ENKÄT]}

\section{Några frågor om Dig och Din roll som anhörigstödjare/strateg/konsulent/samordnare}
$1.1 \mathrm{Du}$ är:
Kvinna Man
Annan

1.2 Vilket år är Du född?

1.3 Vilken/vilka utbildningar har Du?

Sjuksköterska Socionom Arbetsterapeut Beteendevetare Annan

1.4 Annan utbildning av relevans för Ditt nuvarande arbete:

1.5 Vilken är Din [arbets]titel?

1.6 I hur många år har Du arbetat som anhörigstödjare/konsulent/strateg/samordnare?

1.7 Vilken nivå verkar Du på: (flera svar kan anges)
strategisk nivå
operativ nivå

1.8 Ange antal medarbetare i Din kommun som har samma/liknande arbetsuppgifter som Du.

1.9 Hur många invånare finns det i kommunen som Du arbetar i?
Färre än 50000
$50000-150000$
$300000-500000$
Fler än 500000
1.10 Är Din tjänst riktad mot anhöriga till äldre personer? Ja Nej Till viss del
1.11 Har Du en arbetsbeskrivning för Ditt uppdrag? Ja Nej Till viss del

Ange Dina svar genom att markera med ett $X$ (kryss) för det påstående som bäst stämmer överens utifrån Din roll som anhörigstödjare/strateg/konsulent/samordnare.

Instämmer inte alls (1) - Instämmer helt (4).

I Ditt uppdrag/arbete ingår att ge följande stöd:

$1.12 \mathrm{Att}$ ge/förmedla stöd genom att sprida information och kunskap

1.13 Att ge/förmedla stöd $i$ vardagen

1.14 Att ge/förmedla socialt stöd

1.15 Att ge/förmedla hjälp med samordning av insatser

1.16 Att ge/förmedla existentiellt stöd

2. Existentiell ensamhet (en djupare känsla av ensamhet) associerar Du till:

2.1 Livet, mening

2.2 Döende, död, förluster

2.3 Frihet, autonomi, självbestämmande

2.4 Ensamhet, att sakna relationer

2.5 Annat (fritt att skriva)

3. Du ger existentiellt stöd till: 
3.1 Anhöriga som lever tillsammans med sin partner

3.2 Anhöriga vars partner har flyttat till särskilt boende

3.3 Anhöriga vars partner har växelvård

3.4 Anhöriga vars partner är död

3.5 Personal som möter anhöriga

3.6 Volontärer/frivilliga som möter anhöriga

3.7 Andra (fritt att skriva)

\section{I Ditt uppdrag/arbete ingår existentiellt stöd i följande aktiviteter:}

4.1 Förmedla skriftlig information

4.2 Förmedla kontakt till samtalsgrupper

4.3 Organisera och hålla i samtalsgrupper

4.4 Förmedla kontakt till professionell samtalskontakt

4.5 Förmedla kontakt till praktisk hjälp

4.6 Att själv samtala med anhöriga

4.7 Att själv besöka anhöriga

$4.8 \mathrm{Ge}$ personal stöd i existentiella frågor såsom existentiell ensamhet

$4.9 \mathrm{Ge}$ volontärer/frivilliga stöd i existentiella frågor såsom existentiell ensamhet

4.10 Erbjuda utbildning till personal avseende existentiellt stöd

4.11 Erbjuda föreläsningsdagar för anhöriga om existentiella frågor

4.12 Att följa den strategi vi har gällande existentiellt stöd till anhöriga vid min enhet/kommun

4.13 Annat som Du gör för att ge existentiellt stöd (fritt att skriva)

4.14 Följande önskar Du att Du också kunde göra för att ge existentiellt stöd (fritt att skriva)

\section{Du har följande förutsättningar för att ge existentiellt stöd:}

\subsection{Tid i tjänsten}

5.2 Tid finns inte för existentiellt stöd men jag ger stöd utanför min arbetstid

5.3 Kunskap för att möta existentiell ensamhet

5.4 Kunskap för att ge volontärer/frivilliga existentiellt stöd

5.5 Kunskap för att ge anhöriga existentiellt stöd

5.6 Kunskap för att ge personal existentiellt stöd

5.7 Erfarenhet av att möta existentiell ensamhet

5.8 Andra (fritt att skriva) 
ARTIKLAR I-IV 


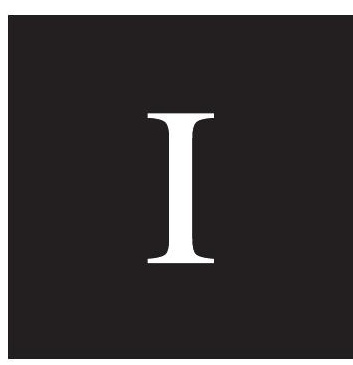




\title{
SPOUSES' EXISTENTIAL LONELINESS WHEN CARING FOR A FRAIL PARTNER LATE IN LIFE - A HERMENEUTICAL APPROACH
}

Helena Larsson, RN, PhD student ${ }^{1,2}$, Margareta Rämgård, PhD, Senior Lecturer ${ }^{1,2}$, Christine Kumlien, PhD, Professor $^{1}$, Kerstin Blomqvist, $\mathrm{PhD}$, Professor ${ }^{2}$

${ }^{1}$ Faculty of Health and Society, Department of Care Science, Malmö University, Malmö, Sweden ${ }^{2}$ Faculty of Health Sciences, Kristianstad University, Kristianstad, Sweden

\begin{abstract}
Purpose: Spouses are in a demanding and vulnerable situation when caring for a frail partner late in life. Exploring their existential loneliness can be a way to understand more about their situation and existential needs. Method: A hermeneutic approach was used. Multistage focus group interviews were conducted with two groups consisting of five spouses, respectively, who met three times each. To work with the text, an approach was adapted where quotations are converted into poems in a linguistic manner. Results: Existential loneliness can be understood as the following: 1) being in a transition from us to merely $m e$, 2) being forced to make decisions and feeling excluded, 3) navigating in an unfamiliar situation and questioning oneself, and 4) longing for togetherness but lacking the energy to encounter other people. The main interpretation is that existential loneliness emerges when one is in moments of inner struggle, when one is forced to make impossible choices, when one is approaching and is in limit situations, and when one is experiencing the endless loss of the other. Conclusion: For health care professionals to achieve a holistic picture, person-centeredness can be a way to make the spouses' existential needs visible and to provide support based on their needs.
\end{abstract}

Keywords: Existential loneliness, spouses, frail partner, hermeneutics, multistage focus group interview, poems

Corresponding author: Helena Larsson, Faculty of Health Sciences, Kristianstad University, SE 29188

Kristianstad, Sweden, Phone: +46 44-2503 947, e-mail: helena.larsson@hkr.se, helena.larsson@ mau.se 


\section{INTRODUCTION}

Existential loneliness seems to occur especially in vulnerable situations (Sjöberg, Beck, Rasmussen, \& Edberg, 2017). One such situation can be caring for a frail partner in the last phase of life. Studies describe how existential loneliness appears when close relationships with other people change (Larsson, Rämgård, \& Bolmsjö, 2017; Sjöberg, Beck, Rasmussen, \& Edberg, 2017). Another aspect is that spouses experience feelings such as guilt, loneliness (Hogsnes, Melin-Johansson, Norbergh, \& Danielsson, 2014), isolation (Neri, Yassuda, Fortes-Burgos, et al 2012; Greenwood, \& Smith, 2016) and aloneness (Førsund, Skovdahl, Kiik, \& Ytrehus, 2014) when their partner becomes increasingly impaired. To enhance the well-being of spouses who care for a frail partner, it is important to understand their existential concerns, where one such concern can be experiences of existential loneliness.

According to Yalom (1980), life involves circumstances when we face existential loneliness, such as our need for freedom and belongingness, our search for meaning, and the inevitable death. Existential loneliness has been compiled in literature reviews as a complex phenomenon (Mayers, \& Svartberg, 2001; Ettema, Derksen, \& van Leeuwen, 2010) intertwined with feelings of emptiness and nothingness (Ettema, Derksen, \& van Leeuwen, 2010). A concept analysis (Bolmsjö, Tengland, \& Rämgård, 2018) reveals how existential loneliness emerges as an immediate and instantaneous perception that we, as human beings, are fundamentally alone, separated from other people. This perception appears especially in times when we become aware of our own mortality or are in a crisis, especially when we are unfamiliar with or not met by others in the situation. Accordingly, negative feelings such as sadness, hopelessness, anxiety and meaninglessness are experienced (Bolmsjö, Tengland, \& Rämgård, 2018). Existential loneliness has also been empirically studied in different health care contexts, for example, in the care of people with aphasia (Nyström, 2006), among women living with HIV (Mayers, \& Svartberg, 2001), in relation to end-of-life care (Sand, \& Strang, 2006), among frail older people (Sjöberg, Beck, Rasmussen, \& Edberg, 2017) and their significant others (Larsson, Rämgård, \& Bolmsjö, 2017), and health care professionals (Sundström, Edberg, Rämgård, \& Blomqvist, 2018). One conclusion that can be drawn from these studies is that existential loneliness is a phenomenon that emerges in vulnerable situations and involves a range of feelings and expressions. Listening to the voices of spouses who care for a frail partner late in life may be one way of learning more about existential loneliness.

Research reveals that one vulnerable situation for a couple late in life is when one of them has to be relocated from their own home to a care home. One study from the UK focused on informal caregivers' experiences, and it describes how the relocation impacted their emotional well-being, where feelings of guilt, helplessness and failure to be able to continue care were prominent (Milligan, 2005). A Swedish study illustrates how spouses experienced guilt and loneliness both before and after relocation (Hogsnes, Melin-Johansson, Norbergh, \& Danielsson, 2014). According to a review from the UK, informal carers over the age of 75 experience a tension between both rewarding feelings and difficult feelings: rewarding when feeling supported by the municipality and having a social network, difficult when feeling isolated and having their own health problems (Greenwood, \& Smith, 2016). Another review compiles spouses' experiences of living with a partner diagnosed with dementia. It shows that the everyday life together changes on all levels, where the overall theme is the irreversible loss of their relationship with their partner (Pozzebon, Douglas, \& Ames, 2016). The loss of a shared couplehood made spouses feel alone and disconnected, not only from their partner but also from society in general (Førsund, Skovdahl, Kiik, \& Ytrehus, 2014). A quantitative study presents how 115 out of 176 older informal carers evaluated caregiving as stressful and isolating (Neri, Yassuda, Fortes-Burgos, et al 2012). When one partner in a togetherness becomes frail, this put demands on the other partner. The situation is, for example, defined as 'Living in the presence of death', where existential concerns - such as existential distress, death anxiety and uncertainty - are revealed (Melin-Johansson, Henoch, Strang, \& Browall, 2012). An empirical study shows how spouses see themselves as followers to the end of life and that they adapt their everyday life to the needs of the dying person (Andersson, Ekwall, Hallberg, \& Edberg, 2010). Understanding existential loneliness from different perspectives, such as that of the spouses', can be a way to discern more about the spouses' situation and existential needs.

The current study is part of a larger research project about existential loneliness (Edberg, \& Bolmsjö, 2019), where one recent study focused on older persons' existential loneliness as interpreted by their significant others (Larsson, Rämgård, \& Bolmsjö, 2017). During the interviews with those who were 104 
spouses, we gained a sense of how they had their own experiences of existential loneliness linked to living close to a frail partner. This led us to the current study. Therefore, the aim of this study was to explore spouses' existential loneliness when caring for a frail partner late in life.

\section{METHOD}

The LONE study, RR2-10.2196/1307 (Edberg \& Bolmsjö, 2019) is in the development phase of designing a complex intervention (MRC, 2008) where existential loneliness is explored through interviews with frail older people (Sjöberg, Beck, Rasmussen, \& Edberg, 2017), their significant others (Larsson, Rämgård, \& Bolmsjö, 2017), and health care professionals (Sundström, Edberg, Rämgård, \& Blomqvist, 2018). The concept 'frail' was defined, according to the LONE study, as older ( $\geq 75)$ persons, late in life and dependent on long-term care or services related to health problems.

\section{Design}

A hermeneutic approach (Gadamer, 1960/1990) was chosen to explore spouses' experiences of existential loneliness when they care for, or had cared for, a frail partner. To explore the experiences indepth, multistage focus group interviews were conducted (Hummelvoll, 2008). The research strategy has a dialogical nature characterized by the same group exploring a topic in depth through several meetings. The researcher decides the topic and functions as a moderator throughout the whole process (Hummelvoll, 2008). In the present study, two focus groups met three times each, which made it possible to follow up narrations about existential loneliness through the multiple meetings. Meeting spouses in a group, instead of individually, enables the participants to reflect upon each other's experiences (Krueger \& Casey, 2015). Hermeneutics is described as an art of interpretation, and working with the text is essential (Gadamer, 1960/1990; Dahlberg, Dahlberg, \& Nyström, 2008). In order to work with the text, an approach used by, among others, Schuster (2006) and Edvardsson, Sandman and Rasmussen (2006), was adapted where quotations are converted to poems in a linguistic manner (Gee, 1985; Gee, 1991). The purpose of using this particular poetically technique was to facilitate what is difficult to describe, thereby giving the reader a better sense of existential loneliness.

\section{Setting}

Nearly 1 million persons in Sweden, approximately $10 \%$ of the population, are 75 years or older (SCB, 2018). The care of older people is primarily a municipal responsibility and is mainly financed by taxes. The formal care is provided by 290 municipalities, and relatives who care for a family member at home have a legal right to support, according to Swedish law (Socialtjänstlagen, 2001:453, 5:10 [Law about Social services]). The support includes, for example, health care and/or service in the home, daily activities arranged by the municipalities, or part-time care at a nursing home. The informal care involves about 1.3 million of the Swedish population (SCB, 2018). In the current study, two municipalities were involved.

\section{Sample and Procedure}

The sample consisted of ten spouses: five men and five women. Inclusion criteria were as follows: have experiences of living together with and caring for a frail partner; consider themselves and their partner as a couple for a long time; and see themselves as the principal responsible for their partner. The first group included spouses whose partner was still alive $(n=5)$, while the second $(n=5)$ included those who had lost their partner within the five last years. Two of the participants, belonging to the first group, became a widow/widower during the data collection period of five weeks. All ten spouses had experiences of living together with and caring for a frail partner, seven had experiences of losing their partner, and five had experiences of how life became after their partner had died. For a description of the sample, see Table 1.

\section{INSERT TABLE 1 ABOUT HERE}

A coordinator in the municipality was contacted and informed about the study through a physical meeting with the first author (HL). The coordinator acted as a link between the researchers and potential spouses, for example by recruiting spouses to participate in the study and asking for permission to 
communicate their name and telephone number to HL. In addition, the coordinator provided potentially interested spouses with a letter of information about the study. The letter contained information about the aim of the study, a description of existential loneliness as a deeper feeling of loneliness, and a guarantee of confidentiality. For informants to feel comfortable talking about and sharing their experiences, each group was to consist of 4-6 participants (Krueger, \& Casey, 2015). In total, 15 names and numbers were communicated to HL, 10 of whom agreed to participate. Reasons for not taking part in the study were an unwillingness to talk about the topic, the informants' own health problems, or not answering the phone, despite repeated calls.

\title{
Data collection
}

Data were gathered by using two focus groups, who met three times each, with each session lasting approximately two hours. The sessions took place between August and October 2018. There was a twoweek interval between session one and two, and a three-week interval between session two and three, with each session recorded and transcribed verbatim. All of the sessions were conducted in a room provided by the municipality, with the group collectively deciding the day and time of the sessions. Both focus groups were kept intact for the duration of all three sessions, and all of the participants, except for one exception in each group, took part in all sessions.

The focus groups were led by HL as moderator and the last author (KB) as an observer. All sessions commence with brief information about the aim of the study. According to Hummelvoll (2008), the first session should serve to create a good atmosphere and let participants become familiar with each other, which was done through allowing all participants to narrate their situation as a spouse. Thereafter, the opening questions (Hummelvoll, 2008) concerned loneliness, in general, and existential loneliness, in particular: How do you experience loneliness in your situation right now? In relation to that, what could you say about existential loneliness? Members in the group who had lost their partner were asked to narrate how they experienced existential loneliness when they had cared for their partner in relation to its present state. Members of both groups were encouraged to describe their experiences in narratives and to reflect upon their own stories and those of others. After each session, the moderator and the observer listened to the recording to review the content (Hummelvoll, 2008) and decided what to deepen regarding existential loneliness for the next session. For a description of the procedure during data collection, see Figure 1.

\section{INSERT FIGURE 1 ABOUT HERE}

\begin{abstract}
ANALYSIS
When all six sessions were completed, a structure for a hermeneutical analysis by Dahlberg, Dahlberg and Nyström (2008) was used. All data were read as a whole text by HL and KB to ascertain a preliminary understanding. Tentative themes emerged and covered the following: changes in life, being left behind, questioning oneself and others, and the absence of togetherness. The tentative themes were presented for all authors, and the second and third author read the data to verify the content. After establishing themes, meaning units (not too short, rather a whole narrative) were extracted (Dahlberg, Dahlberg, \& Nyström, 2008). Dialogue as a means of working with a text (Gadamer, 1960/1990) is exemplified by Schuster (2006) and Edvardsson, Sandman and Rasmussen (2006), whose approach we adopted. It concerns working with a text in a linguistic manner through converting quotations into poems (Gee, 1985; Gee, 1991). The poem is constructed by choosing a central quote, i.e. a text that clearly illustrates the essence of the theme; reading it slowly; dividing the quote into stanzas, usually four lines; notice pauses, false starts, hesitations; and considering the meaning of each word in order to catch the essence of the text (Gee, 1985; Gee, 1991; Schuster, 2006). The process facilitated the interpretation because a poem is read slowly; for example, as one's breathing becomes calmer when reading poetry (Rämgård, \& Nieminen Kristofersson, 2010; Schuster, 2006), the poem is read with another sense. Only the quotations presented in this paper were converted into poems. When poems were established for each of the four themes, the writing commenced to enable the reader to understand how the interpretation had progressed (Schuster, 2006). Finally, a main interpretation was conducted to create an understanding of the whole (Gadamer, 1960/1990; Dahlberg, Dahlberg, \& Nyström, 2008).
\end{abstract}


During analysis and in the interviews, it was important to be aware of the pre-understanding. A hermeneutic horizon of understanding emphasizes that pre-understanding should be considered an unavoidable fact and be used as an asset (Gadamer, 1960/1990). This was done by continually discussing and comparing the interpretations with our pre-understanding. Because the four authors have different professional backgrounds - including caring science, geriatric nursing, surgical care and human geography - it was possible to look at data with different perspectives.

\section{Ethical considerations}

The study was approved by the Ethical Review Board, Lund, Sweden (Reg.no. 2018/422). The first session, in both groups, commenced with information about ethical issues, such as voluntary participation and confidentiality. All participants signed an informed consent. Thereafter, all three sessions started with a reminder of voluntary participation.

\section{FINDINGS}

Spouses' existential loneliness when caring for a frail partner can be understood according to four themes: 1) being in a transition from us to merely $m e, 2$ ) being forced to make decisions and feeling excluded, 3) navigating in an unfamiliar situation and questioning oneself and, 4) longing for togetherness but lacking the energy to encounter other people.

\section{Being in a transition from us to merely me}

Being in a life-changing event that is not self-chosen and not possible to influence causes the emergence of existential loneliness. The text describes a longing for life together as it once was and, simultaneously, an awareness that the changes that occur are irreversible and permanent, and that life will never ever be the same again. In the poem below, we follow a husband's experience when he begins to feel that something is not right with his wife.

I did not recognize her

passive

sat on the couch

[M: Do you miss her?]

Yes!

how she was before

oh, yes

I can handle it yet

but

slowly but surely it will become worse

before we have complemented each other well

but now it is not so good anymore

unfortunately

The first part of the poem covers how it was then, when the man realized that his wife changed to the unrecognizable. In the last part, he is in the present, and the change in the relationship emerges. Previously, they 'complemented' each other, but not any longer. The text describes uncertainty for the future with the words 'slowly but surely worse' and sadness in the word 'unfortunately'. 
Another example of the transition is the use of language. The text continues to talk about us and me. In the poem below, we follow the conversation between two women talking about how they now are supposed to speak: whether they should say $I$ or $u s$ ?

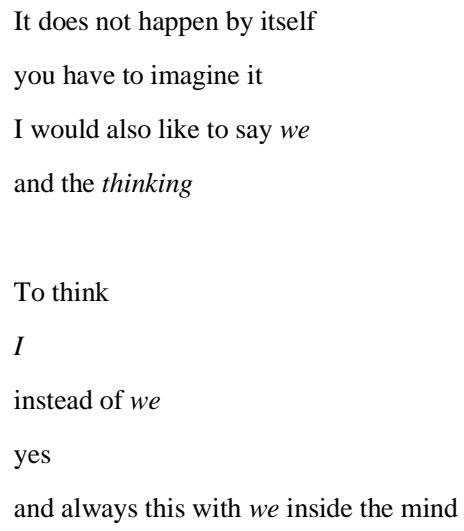

The text describes how they have always imagined themselves as one, as a we, but now they need to start to think of themselves as merely me. To imagine merely me as I, instead of we, does not come spontaneously; rather it needs a directed, conscious thought. The words 'does not happen by itself' talk about how strange it is to imagine me, as only I, instead of we. Similarly, the words 'inside the mind' relate that a transition takes time. Living as we is a deeply rooted feeling, and it takes time to change the image from we to only me. The text continues with narratives about feeling like a half person when 'we' no longer exists. In the poem below, we follow a woman in her narrative a time after her husband's death, a time when she can look back at 'then'.

$$
\begin{aligned}
& \text { Emptiness } \\
& \text { but somehow } \\
& \text { a relief } \\
& \text { but for the most part } \\
& \text { a great emptiness }
\end{aligned}
$$

After fifty years together

I felt like

a half person

I did

Since there is a description of relief, we can imagine that there has been a time of anguish, otherwise the word relief would never have had to be used; thus the relief was preceded by anguish. Likewise, we can understand from the words 'a half person' that the feeling of being a whole person has existed previously. To go from feeling like a whole person to feeling like a half person means we can understand that losing one's life companion is a crucial event in a person's life. It involves to live in a transition from $u s$ to merely me.

\section{Being forced to make decisions and feeling excluded}

To surrender a life-companion into the hands of others is considered as an impossible choice. However, it is a decision the spouses feel obligated to make, and it is one that causes the emergence of existential loneliness. A decision must be made even though no alternative is satisfying. The choice is not only 
devastating but also crucial for the rest of their lives. In the poem below, we follow a woman's illustration of how it was the very first time she entrusted her husband to part-time care at a nursing home.

\author{
When I left him the first time \\ for the very first time \\ worried about how it would be like \\ I know how he is at home
}

And I was instructed not to visit him during that following week

and neither did I

I picked him up later

And then I thought

maybe I might try to have him at home anyway

I do not want to expose myself to this

The text deals with the spouses surrendering their partner into care for the first time as a decisive stage. On the one hand, spouses do not want to make decisions, but, on the other hand, doubts are expressed as with the word 'instructed' - about the decisions of others. Doubts about their own decisions are also expressed with 'I might try'. Thus, the wife considered the possibility of caring for her husband at home a little longer. That the situation is perceived as painful is made clear at the end of her depiction with the words 'I do not want to expose myself to this'.

The text concerns not only experiences of how it is to surrender a partner to care but also how difficult it is to be the one who left is behind, thereby becoming excluded. To be forsaken and excluded cause existential loneliness to surface. In the poem below, we follow a man's portrayal of how it was when his wife excluded him.

$$
\begin{aligned}
& \text { I had looked after her } \\
& \text { during the nights } \\
& \text { all of the time } \\
& \text { and helped }
\end{aligned}
$$

And then Friday night

she asked for herself

a nurse to arrange something

it went very quickly

It was the most difficult day for me

she moved away from our home

through her own free will

it was heart-breaking 
She wanted to move away from the home we had built up together for sixty years

she thought she was getting better help

at another place

It was difficult

I knew

she would not come back

The text contains the words 'through her own free will' and is understood as the man feeling forsaken by his wife. After having taken care of her day and night, she chooses to leave him. His narration conveys that no matter how much he did for her he was not enough because she thought that she was getting better help from someone else. Expressions such as 'it was heart-breaking' and 'difficult' encompass that to be forsaken and excluded is a painful situation. At the end of the poem, the awareness of the definitive separation is expressed by the words 'I knew, she would not come back'.

\section{Navigating in an unfamiliar situation and questioning oneself}

To be in an unfamiliar situation without knowing how to navigate causes existential loneliness to surface. In the poem below, we follow a woman describing her unfamiliar situation with the metaphor of being in a bubble, as in a vacuum.

Like to be in a bubble

I know that someone called

I answered and they said

How are you?

Well, I said

I do not know

I think I am in some kind of bubble

I do not know

trapped

in a vacuum

Then you are alone

you do not really know what to do

in this bubble

The bubble was horrible

after all, it has limits

it has been like a vacuum

Words such as 'it has limits' express feeling disconnected from a context. The bubble is referred to as 'horrible', so the feeling is something unpleasant, something to be avoided. Being in the bubble is a situation of ambivalence, hesitation and, simultaneously, a paralysis because it is portrayed with the words 'you do not really know what to do'. The bubble is also referred to as 'then you are alone', so the bubble has a delimited time frame that stays in one's mind. In the poem below, the depiction continues, 
partly with the same woman's reflection, partly at the end with another woman's confirmation that it is difficult to understand another person until you, yourself, have been there.

\author{
It is strange, you know \\ it is also strange, based on what I have worked with \\ I have worked with people all of my life \\ You never become immune \\ when it happens to you, it is something other \\ than what you have seen others experience \\ and you have believed that you have understood
}

The text deals with the fact that though having previously thought or having said to others that they understand, they now realize how they do not understand, not until they themselves experience something similar. The word 'strange' shows that in the woman's self-reflection, she is surprised: she had not expected the situation to feel like this. The text reveals that it is painful to question oneself in a self-reflection. At the end of the poem, the text relates 'you have believed that you have understood', where the word 'believed' shows that the woman now realizes that she has not understood what people previously experienced. In the text, the words 'you never become immune' show how feelings and situations like this are difficult to defend oneself from. The endeavour in life can be to protect oneself, to become immune, but it is impossible to become immune to difficult situations such as being trapped in a bubble, delimited in a vacuum. This is one kind of situation that can be understood as navigating in an unfamiliar situation and as questioning oneself.

\title{
Longing for togetherness but lacking the energy to encounter other people
}

Having previously, for several years, belonged to a given context with another person who is now transforming to the unrecognizable or is lost through death causes the emergence of existential loneliness. The text describes how difficult it can be to find a new context and, at the same time, how difficult it can be to remain in the previous contexts when no longer a couple. In the poem below, we follow a wife in her description of how it was when her husband moved to a nursing home and they celebrated their first Christmas together in a new context.

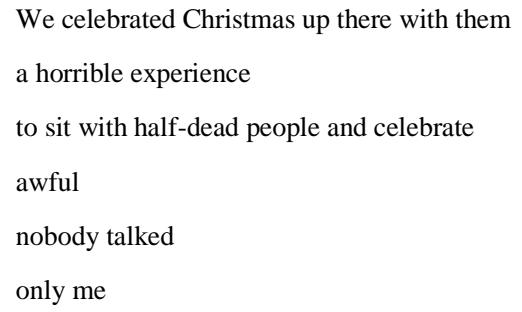

The text relates that we celebrated Christmas with them. The absence of belongingness and togetherness is total and is expressed in words such as 'half-dead people' and 'nobody talked'. The words 'only me' can be understood as if the woman felt lonely even though the room was full of people. Expressions such as 'horrible' and 'awful' indicate that this is a context she does not want to be in. She lives with her husband but cannot feel togetherness with him or his context.

The text continues with depictions of a longing for togetherness with other people, especially when the partner no longer lives. In the poem below, we follow a woman in her longing to be close to other people and to share her thoughts with others and, simultaneously, how difficult it can be to have the energy to do so. 
When I am at home

I just wander

cry

I feel this [pointing with both hands towards the chest]

very concrete

So, in order to disperse this [pointing with both hands towards the chest]

I have to get out

but then again, that togetherness

that I might experience for a while

it lasts only a little while

then I have to go home behind my closed door anyway

But then

you may not have the energy to take part in that gathering

I slipped out through the back door

I felt that I could not

could not be a part of that gathering that should be a given for me

The text conveys a longing for togetherness, but, at the same time, a struggle to find the energy to encounter other people. This is related through the notion of trying to meet other people while slipping out through the back door and not wanting to be alone at home and wandering and being reminded of the emptiness but, simultaneously, not being able to stay away. The word 'this' together with both hands pointing towards the chest becomes an expression of the emptiness that appears when the context and the togetherness with a life-companion is broken forever.

\section{DISCUSSION \\ Main interpretation}

The main interpretation is that existential loneliness emerges when one is in moments of inner struggle, when one is forced to make impossible choices, when one is approaching and is in limit situations, and when one is experiencing the endless loss of the other. The themes can be comprehended as if the spouses are in a process that leads to the inevitable final destination in their relationship with their partner. With descriptions such as 'I felt like a half person', the poems can be explained and understood as if the experience is like that of being torn apart. The process can be understood in line with Jaspers's (1994) description of limit situations, where an unavoidable limit has been reached which the spouses can neither escape from nor defend themselves from. A previous study has shown that existential loneliness can be understood as a feeling of being totally separated from other people (Bolmsjö, Tengland, \& Rämgård, 2018). The interpretation of limit situations can be understood through poems as being trapped in a bubble that has limits. Another explanation of 'the bubble' is found in Yalom's (1980) metaphor of existential isolation, illustrated as a valley. To face dying and death inevitably leads to the valley. Some of the poems also allow us to understand that limit situations have a definite time frame. The poems describe a clear direction, with words like 'this' or 'then'. The direction, therefore, indicates that the spouses know exactly where the feeling is inside, but that they find it difficult to put into words. Instead, the hands are used to show the direction of the feeling, for example, pointing with both hands towards the chest. The direction is also about time: the time of being in the bubble, in the ambivalence - the limit can clearly be described to a delimited time. This has been addressed in the 
study by Bolmsjö, Tengland and Rämgård (2018), where existential loneliness is described as an immediate and instantaneous perception: right in that moment, probably impossible to escape from for the spouses. The poems can also be understood as if the spouses feel alone in their struggle, and we can assume that they do not feel encountered at a deeper level, which is described as a situation that causes existential loneliness to emerge (Bolmsjö, Tengland, \& Rämgård, 2018).

In the themes, situations of choice appear as central. In the poems, we can understand that the spouses pose constant questions, such as 'If I do like this - will it be better for him then?' and, on the other hand, 'If I do like that - would it be better?' The spouses experience that they have no choice; rather, they feel compelled to make decisions that are not satisfying, such as surrendering their partner to a nursing home or accepting the change that takes place with their partner. The poems can be understood as if the spouses are in an inner struggle with themselves. They want to do good; but whatever they choose to do, their choice will not be satisfying for either themselves or their partner. To be in this battle is to experience existential loneliness. Tillich (1952/2000) asserts that everyone is in a constant tension between oneself and the world. The choices we make are not satisfying, but not to choose is, as Sartre (1947/2007) claims, also a choice. It is unpleasant to be forced into a choice that causes anxiety. Tillich (1952/2014) maintains that constant, inevitable choices cause anxiety, and an expression of existential loneliness is anxiety (Bolmsjö, Tengland, \& Rämgård, 2018).

A contemporary philosophy is person-centeredness, which has its starting point in each person's unique desires and a strengthening of trust in their own choices (McCormack, \& McCance, 2017). To support the spouses in their choice is important. All of the spouses' partners are provided with continuous care. Both involving and listening to the spouses through the process of care is crucial (SØvde, Hovland, Ullebust, \& Råholm, 2018). Studies highlight the significance of supporting, listening to and catering for the needs of close relatives who, in various ways, care for a family member ( $c f$. Totman, Pistrang, Smith, Hennessey, \& Martin, 2015). Accordingly, preventive work should also centre on those who are in the patient's absolute vicinity, that is, to include them in a person-centred care. However, personcentred care can be distinguished as including only the person in need of care. The spouses in the present study have lived in a togetherness for 50 years, they are one, as a unit, rather than two separate individuals. Jaspers (1971/1995) relates the importance of looking at the whole situation, because if we only look at certain parts, the picture becomes fragmented and impossible to perceive correctly; thus it becomes skewed and misleading. Actively targeting the idea towards a holistic picture, that is personcenteredness (McCormack, \& McCance, 2017), can be a way to make the spouses' own needs visible.

\section{Methodological considerations}

To strengthen the dependability (Shenton, 2004), variation in the sample was required. Consequently, we aimed to reach not only those spouses who had care responsibilities at that time but also those whose partner had died within the last five years. The sample involves spouses who have lived with their partner for a long time. As the median is 51.5 years, it can be seen as a measure for sharing experiences from a relational perspective. The method, multistage focus group interviews (Hummelvoll, 2008), was chosen because we wanted to reach a deeper reflective dialogue. We also strove towards an atmosphere built on trust as we wanted the participants to talk about what can be construed as a difficult topic. Therefore, it was vital to meet the participants several times over a prolonged period. During the data collection, we were one junior researcher and one senior researcher, both of whom were familiar with conversations about existential issues. In order for the reader to verify (Shenton, 2004) the analysis, each step is described in the method, in a figure and in poems. The results are presented in such a manner that it is possible for the reader to verify how the interpretation progressed. To safeguard confirmability, the awareness of our preunderstanding was important (Shenton, 2004), where one measure is our different professional backgrounds. Regarding the transferability (Shenton, 2004), the informants were identified from two municipalities and their partner was given care from different care contexts; this may strengthen the transferability.

\section{Conclusion and clinical implications}

The main value of this study is a deepened understanding of existential loneliness when caring for a frail partner late in life. The main interpretation is that existential loneliness emerges when one is in moments of inner struggle, when one is forced to make impossible choices, when one is approaching and is in 
limit situations, and when one is experiencing the endless loss of the other. The spouses are in a vulnerable and demanding situation. For health care professionals to accommodate and support spouses in their demanding situation, knowledge and understanding of existential concerns are important. To achieve a holistic picture that includes acknowledging people's physical, social, emotional and existential needs, person-centeredness can be a way to make the spouses' existential needs visible by listening and being present. In addition, a topic for further research is to develop existential support specifically targeted to spouses who care for a frail partner late in life.

\section{Acknowledgements}

We are most grateful to the spouses who shared their experiences with us and to the coordinators at the municipalities for the help with establishing contact with the spouses.

\section{Notes on contributors}

Helena Larsson, RN, is a PhD student in Care Science at the Faculty of Health and Society, Malmö University and at the Faculty of Health Sciences, Kristianstad University, Sweden.

Margareta Rämgård, RN, is a senior lecturer in Care Science and Human Geography at the Faculty of Health and Society at Malmö University, Sweden.

Christine Kumlien, RN, is a Professor in Care Science at the Faculty of Health and Society, Malmö University, Sweden.

Kerstin Blomqvist, RN, is a Professor in Nursing at the Research Platform for Collaboration for Health, Faculty of Health Sciences, Kristianstad University, Sweden.

\section{Author contribution}

H.L., M.R., C.K. and K.B. designed the study. H.L. and K.B. collected and analysed the data. M.R. and C.K. read the data to verify the content. All authors have contributed substantially to the final manuscript and approved it for publication. 


\section{References}

Andersson, M., Ekwall, A., Hallberg, IR. \& Edberg, AK. (2010). The experience of being next of kin to an older person in the last phase of life. Palliative and Supportive Care, 8(1), 17-26.

Bolmsjö, I., Tengland, P-A. \& Rämgård, M. (2018). Existential Loneliness: An attempt at an analysis of the concept and the phenomenon. Nursing Ethics, 1-16. doi10.1177/0969733017748480 [Epub ahead of print].

Dahlberg, K. Dahlberg, H. \& Nyström, M. (2008). Reflective Lifeworld Research. Lund: Studentlitteratur.

Edberg, AK. \& Bolmsjö I. (2019). Exploring existential loneliness among frail older people as a basis for an intervention: Study protocol of the development phase of the LONE study. RR2-10.2196/1307, JMIR Research Protocols Doi:10.2196/1307.

Edvardsson, D., Sandman P.O. \& Rasmussen, B. (2006). Caring or uncaring - meanings of being in an oncology environment. Journal of Advanced Nursing, 55(2): 188-197.

Ettema, EJ., Derksen, LD. \& van Leeuwen, E. (2010). Existential loneliness and end-of-life care: A systematic review. Theoretical Medicine and Bioethics, 31, 141-169.

Førsund, L. H., Skovdahl, K., Kiik, R. \& Ytrehus, S. (2014). The loss of a shared lifetime: a qualitative study exploring spouses' experiences of losing couple hood with their partner with dementia living in institutional care. Journal of Clinical Nursing, 24, 121-130.

Gadamer, G-H. (1960/1990). Sanning och metod [Truth and Method]. Göteborg: Daidalos AB.

Gee, J.P. (1985). The Narrativization of experience in the oral style. The Journal of Education, 167(1), 9-35.

Gee, J.P. (1991). A Linguistic approach to narrative. Journal of Narrative and Life History, 1(1), 15-39.

Greenwood N. \& Smith, R. (2016). The oldest carers: A narrative review and synthesis of the experiences of carers aged over 75 years. Maturitas, 94, 161-172.

Hogsnes L., Melin-Johansson, C., Norbergh K G. \& Danielsson, E. (2014). The existential life situations of spouses of persons with dementia before and after relocating to a nursing home. Aging \& Mental Health, 18(2), 152-160.

Hummelvoll, J.K. (2008). The multistage focus group interview. Norsk Tidskrift for Sykepleieforskning, 10(1), 3 14.

Jaspers, K. (1994). Philosophy II. Illumination of existence. Munich: Piper.

Jaspers, K. (1971/1995). Philosophy of Existence. University of Pennsylvania Press.

Krueger, R. \& Casey, M. (2015). Focus Groups. A Practical Guide for Applied Research. $5^{\text {th }}$ ed. Thousand Oaks: Sage.

Larsson, H., Rämgård, M. \& Bolmsjö, I. (2017) Older persons’ existential loneliness, as interpreted by their significant others - an interview study. BMC Geriatrics, 17, 138.

Mayers, AM. \& Svartberg, M. (2001). Existential loneliness: A review of the concept, its psychosocial precipitants and psychotherapeutic implications for HIV-infected women. British Journal of Medical Psychology, 74, 539-553.

McCormack, B. \& McCance, T. (2017). Person-Centred Practice in Nursing and Health Care. Theory and Practice. $2^{\text {nd }}$ ed. Wiley Blackwell.

MRC, Medical Research Council. (2008). Developing and Evaluating Complex Interventions: New Guidance. London: Medical Research Council.

Melin-Johansson, C., Henoch, I., Strang, S. \& Browall, M. (2012). Living in the presence of death: an integrative literature review of relatives' important existential concerns when caring for a severely ill family member. The Open Nursing Journal, 6, 1-12.

Milligan, C. (2005). From home to 'home': Situating emotions within the caregiving experience. Environment and Planning, 37(12), 2105-2120. 
Neri, A., Yassuda, M.S., Fortes-Burgos, AC et al (2012). Relationships between gender, age, family, conditions, physical and mental health, and social isolation of elderly caregivers. International Psychogeriatrics, 24(3), 472483.

Nyström, M. (2006). Aphasia-an existential loneliness: A study on the loss of the world of symbols. International Journal of Qualitative Studies on Health and Well-being, 1, 38-49.

Pozzebon, M., Douglas, J. \& Ames, D. (2016). Spouses' experience of living with a partner diagnosed with a dementia: a synthesis of the qualitative research. International Psychogeriatrics, 2(4), 537-556.

Rämgård, M. \& Nieminen Kristofersson, T. (2010). "Låt inte spindelväven växa i ditt hjärta" En forskningscirkel om poesins verkan för sjuksköterskor i palliativ vård. ["Don't let the cobwebs grow in your heart"]A study circle about the poetry's effect on nurses in palliative care]. FoU Skåne Skriftserie 2010: 3.

Sand, L. \& Strang, P. (2006). Existential loneliness in a Palliative Home Care Setting. Journal of Palliative Medicine, 9, 6.

Sartre, J-P. (1947/2007). Existentialism is a humanism. New Haven \& London: Yale University Press.

SCB, Statistics Sweden (2018). Population statistics. https://www.scb.se/hitta-statistik/statistik-efteramne/befolkning/befolkningens-sammansattning/befolkningsstatistik/

Schuster, M. (2006). Profession och Existens: En hermeneutisk studie av asymmetri och ömsesidighet $i$ sjuksköterskors möten med svårt sjuka patienter. [Profession and existence] Göteborg: Daidalos.

Shenton, AK. (2004). Strategies for ensuring trustworthiness in qualitative research projects. Education for Information, 22, 63-75.

Sjöberg, M., Beck, I., Rasmussen, B. \& Edberg, AK. (2017). Being Disconnected from Life-Meanings of Existential Loneliness as Narrated by Frail Older People. Aging \& Mental Health, doi: 10.1080/13607863.2017.1348481.

Socialtjänstlagen, 2001;453, 5:10. [Swedish Law about Social Services] https://www.riksdagen.se/sv/dokumentlagar/dokument/svensk-forfattningssamling/socialtjanstlag-2001453_sfs-2001-453

Sundström, M., Edberg, AK., Rämgård, M., \& Blomqvist, K. (2018). Encountering existential loneliness among older people: perspectives of health care professionals. International Journal of Qualitative Studies on Health and Well-being, 13(1), 1474673.

Søvde, B. E., Hovland, G., Ullebust, B. \& Råholm, M-J. (2018). Struggling for a dignifying care: experiences of being next of kin to patients in home health care. Scandinavian Journal of Caring Sciences, doi:10.1111/scs.12638.

Tillich, P. (1952/2000). The courage to be. $3^{\text {rd }}$ ed. New Haven \& London: Yale University Press.

Totman, J., Pistrang, N., Smith, S., Hennessey, S. \& Martin, J. (2015). 'You only have one chance to get it right': A qualitative study of relatives' experiences of caring at home for a family member with terminal cancer. Palliative Medicine, 29(6), 496-507.

Yalom, I.D. (1980). Existential psychotherapy. New York: Basic Books. 
Table 1. Description of the sample

\begin{tabular}{|c|c|c|c|}
\hline \multicolumn{2}{|l|}{ Informants } & \multicolumn{2}{|c|}{$\mathrm{n}=10$} \\
\hline \multicolumn{2}{|l|}{ Men/women } & \multicolumn{2}{|l|}{$5 / 5$} \\
\hline \multicolumn{2}{|l|}{ Age, median (range) } & \multicolumn{2}{|c|}{79.5 year (67-89 years) } \\
\hline \multicolumn{2}{|l|}{ Lived together, median (range) } & \multicolumn{2}{|c|}{51.5 years $(46-65$ years $)$} \\
\hline \multicolumn{2}{|l|}{ Widow/widower, median (range) } & $3 / 2$ & 2 years (1-4 years) \\
\hline \multicolumn{4}{|l|}{ Partner's main concern } \\
\hline \multicolumn{2}{|l|}{ Dementia } & \multicolumn{2}{|l|}{6} \\
\hline \multicolumn{2}{|l|}{ Cancer } & 3 & \\
\hline \multicolumn{2}{|l|}{ Other } & \multicolumn{2}{|l|}{1} \\
\hline \multicolumn{4}{|l|}{ Partner's care contact } \\
\hline \multicolumn{2}{|l|}{ Living/lived at home } & \multicolumn{2}{|l|}{5} \\
\hline \multicolumn{2}{|l|}{ Municipal home care } & \multicolumn{2}{|l|}{3} \\
\hline \multicolumn{2}{|l|}{ Municipal home service } & \multicolumn{2}{|l|}{3} \\
\hline \multicolumn{2}{|c|}{ Specialised palliative home care } & \multicolumn{2}{|l|}{3} \\
\hline \multicolumn{2}{|c|}{ Residential care } & \multicolumn{2}{|l|}{5} \\
\hline \multicolumn{2}{|c|}{ Lived in the same municipality, median (range) } & \multicolumn{2}{|c|}{47 years $(5-86$ years $)$} \\
\hline \multicolumn{2}{|c|}{ If something happens, do you have anyone to contact? } & \multicolumn{2}{|c|}{ All answered yes } \\
\hline \multirow[t]{3}{*}{ Do you have anyone who relieves/d you? } & Yes & \multicolumn{2}{|l|}{5} \\
\hline & No & \multicolumn{2}{|l|}{1} \\
\hline & Has/had no need & \multicolumn{2}{|l|}{4} \\
\hline
\end{tabular}




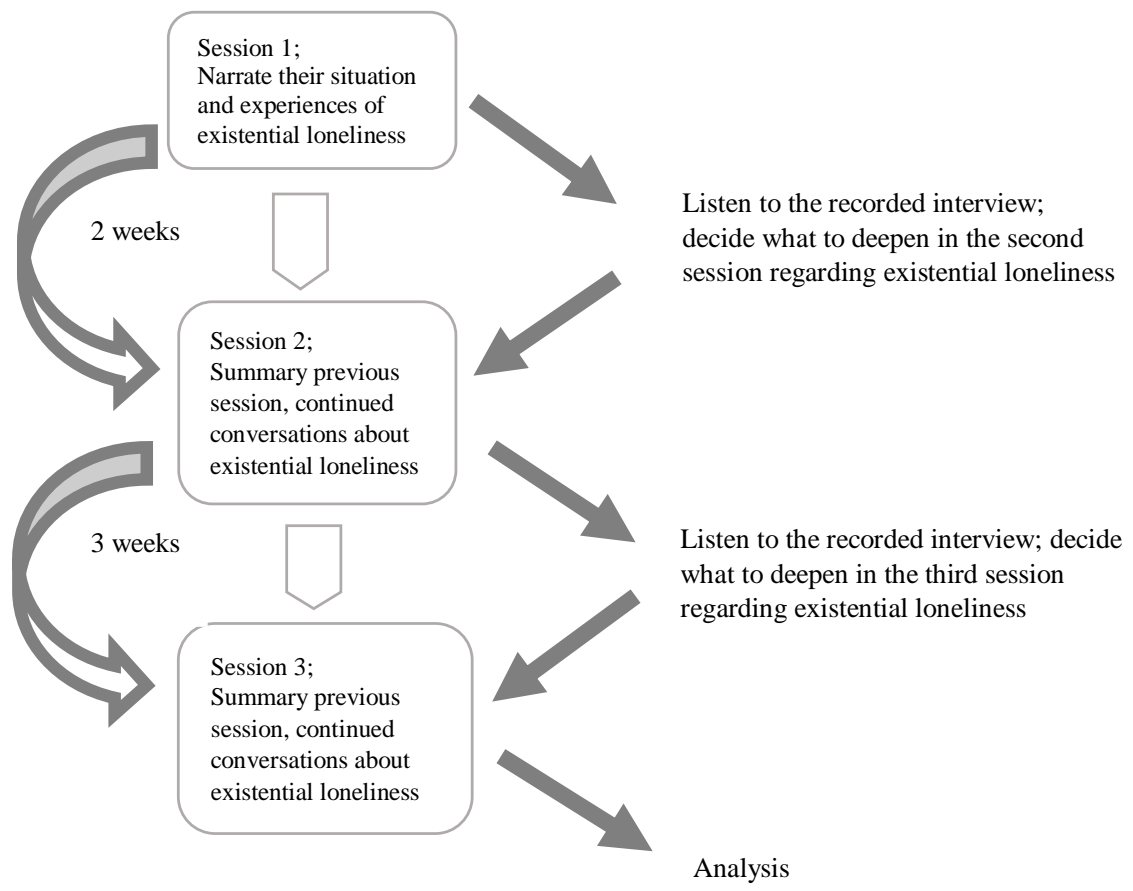

Figure 1. Description of the procedure during data collection 
II 


\title{
Older persons' existential loneliness, as interpreted by their significant others - an interview study
}

\author{
Helena Larsson ${ }^{1,2^{*}}$ (D), Margareta Rämgård ${ }^{1}$ and Ingrid Bolmsjö ${ }^{1}$
}

\begin{abstract}
Background: In order to better understand people in demanding medical situations, an awareness of existential concerns is important. Studies performed over the last twenty years conclude that when dying and death come closer, as in the case with older people who are stricken by infirmity and diseases, existential concerns will come to the fore. However, studies concerning experiences of existential loneliness (EL) are sparse and, in addition, there is no clear definition of EL. EL is described as a complex phenomenon and referred to as a condition of life, an experience, and a process of inner growth. Listening to someone who knows the older person well, as significant others often do, may be one way of learning more about EL.

Methods: This study is part of a larger research project on EL, the LONE study, where EL is explored through interviews with frail older people, their significant others and health care professionals. The aim of this study was to explore frail older (>75) persons' EL, as interpreted by their significant others. The study is qualitative and based on eighteen narrative interviews with nineteen significant others of older persons. The data was analysed using Hsieh and Shannon's conventional content analysis.

Results: According to the interpretation of significant others, the older persons experience EL (1) when they are increasingly limited in body and space, (2) when they are in a process of disconnecting, and (3) when they are disconnected from the outside world.

Conclusion: The result can be understood as if the frail older person is in a process of letting go of life. This process involves the body, in that the older person is increasingly limited in his/her physical abilities. The older person's long-term relationships are gradually lost, and finally the process entails the older person's increasingly withdrawing into him- or herself and turning off the outside world. The result of this study is consistent with previous research that has shown that EL is a complex phenomenon, but the implications of this research include a deepened understanding of EL. In addition, the study highlights the interpretations of significant others.
\end{abstract}

Keywords: Existential loneliness, Significant other, Older person, Qualitative, Interview study, Content analysis

\section{Background}

Globally, with advances in medicine helping more people to live longer lives, the number of people over the age of 60 is expected to double within the next thirty years and reach two billion [1]. This demands radical societal changes, especially in order to ensure well-being, meaningfulness, and dignity for older people [2].

\footnotetext{
* Correspondence: helena.larsson@hkr.se; helena.larsson@mah.se ${ }^{1}$ Faculty of Health and Society, Department of Care Science, Malmö University, SE 20506 Malmö, Sweden

${ }^{2}$ Department of Health and Society, Kristianstad University, SE 29188 Kristianstad, Sweden
}

Furthermore, in order to better understand people in demanding medical situations, an awareness of existential concerns is important. Studies performed over the last twenty years conclude that when dying and death come closer, as in the case with older people who are stricken by infirmity and diseases, existential concerns will come to the fore [3-5]. In the health care context, the professionals need to be prepared to take care of the different needs of patients', as well as of their significant others', and not merely medical problems but also psychological and existential needs should be in focus [6]. However, 
studies show that professionals see existential concerns as a challenge $[7,8]$. Studies also point out that the health care system fails to involve and take advantage of significant others' knowledge and perception of the older persons' situation $[9,10]$. Thus, in order to provide adequate care and obtain a better understanding of how to meet older people in situations where existential needs appear, additional research on existential concerns is called for.

One existential issue in human life is existential loneliness (EL). A literature review by Mayers and Svartberg describes EL as a basic sense of loneliness that may occur when we, as human beings, face the fact that we are all alone in the world despite having other people around, but the review concludes, that the experiences of EL are unclear [11]. Another review views EL as a concept that consists of three dimensions: EL as a fundamental condition of human existence since we, as human beings, are separated from others; EL as an experience of loneliness without any relatedness to other people, described as feelings of nothingness and emptiness; and EL as a process of inner growth in which the negative experience of humans' lonely nature is transformed into something positive [12]. Further, the psychotherapist Yalom, who has explored existential concerns in human beings' lives, has referred to EL as a stipulation of life and pointed to how life itself involves EL. He writes about what he calls "the ultimate concerns", such as the inevitability of death, our need of freedom and belongingness, and our search for meaning [13], which are all connected to EL. A number of philosophers have also written about the existential dimension of loneliness [14, 15]. Paul Tillich, for example, writes that being a human is to exist in a body that is alone and isolated, separated from everyone else's [14]. Victor Frankl points out that the existential dimension of loneliness is never something that we can ignore, since it is part of being a human [15]. In addition, EL has been mentioned in qualitative studies within the health care context, especially when dying and death come closer $[16,17]$. According to the literature referred to above, $\mathrm{EL}$ is a phenomenon that does exists, but despite the fact that philosophers and researchers have tried to clarify $\mathrm{EL}$, there is still an indistinctness with regard to the experiences of EL and how EL is communicated. Thus, empirical studies would be helpful in understanding the phenomenon.

Listening to the voices of significant others may be one way of learning more about EL. It is well known that significant others play a crucial role for older persons' well-being $[10,18]$, and they might be the ones who are closest to the older person and the ones who can provide invaluable information about the older person's situation [19]. Qualitative studies describe the multifaceted role of being a significant other of older persons in need of care $[20,21]$, and this role is exhausting not only physically but also psychologically [22]. However, research also points to the fact that significant others want to take part in the care, and feelings of joy and satisfaction are described when significant others feel that they are counted on and listened to [19, 23]. Despite this, research reveals that significant others are often excluded when they should instead be seen as an asset $[10,24]$ and as a resource, that is, as experts and as companions in the care of older persons [9, 24, 25]. The studies performed during the last ten years, referred to above, concerning the experiences of significant others', have primarily focused on how significant others perceive the care the older persons receive in their home or in hospital, or on how they themselves, as significant others, experience the situation of being close to someone who is aging. So far, there are few studies with a focus on how significant others notice and perceive existential phenomena experienced by their aging relative or friend, despite the fact that researchers and professionals point out the importance of listening to the voices of significant others in order to better understand older peoples' needs. Early detection of existential suffering among frail older people is essential in order to prevent impaired existential health $[4,26]$ and in this endeavour the voices of significant others could be a valuable resource. Listening to someone who knows a person well [19], as significant others often do, might be helpful in identifying existential needs at an early stage.

Studies concerning experiences of EL are sparse and, in addition, there is no clear definition of EL $[11,12]$. EL is described as a complex phenomenon [12], and, hence, multiple approaches are called for in order to explore and clarify the phenomenon. Therefore, empirical studies in general are needed, and in particular studies exploring the experiences of older people living in the nearness of death. Furthermore, exploring other kinds of views, such as those of significant others, might also generate a deeper understanding of the phenomenon. Hence, the aim of this study was to explore frail older $(>75)$ persons' EL, as interpreted by their significant others. This study is part of a larger research project on EL, the LONE study [27], where EL is explored through interviews not only with significant others but also with frail older people and health care professionals. The LONE study is in the development phase of designing a complex intervention [28].

\section{Methods}

Since this study aims to explore human experiences, it is descriptive with a qualitative design [29]. The data was analysed using Hsieh and Shannon's approach to conventional content analysis which allows interpretation of 
the content of data through a process of coding and categorising [30]. Hsieh and Shannon's approach was chosen since their method is often used in a health care context, and since it is well described as well as useful in structuring a great amount of data. Moreover, this type of design and method for analysis seemed appropriate, since existing knowledge regarding EL is limited and since the aim was to explore a phenomenon as perceived through someone else's eyes, rather than as experienced first hand $[29,30]$.

\section{Participants}

The concept "frail older people" was defined as older persons $>75$ in need of long-term care related to multiple diagnoses, physical disorders, and functional impairments. The care was given by formal caregivers from the municipality or the county council. We hypothesised that older persons, who are stricken by infirmity and diseases, and who are likely to have suffered many different losses since they have lived for a long time, have experienced EL, and therefore we chose to ask them, their significant others and health care professionals about EL. Through interviews with frail older people $(n=23)$ (for a description of the care contexts, age, and gender, see Table 1), carried out by another researcher, the informants for this study were identified. The older persons were identified by a designated contact person at each care unit who provided oral and written information about the study. If the older person gave his/her allowance his/her name was communicated to one of the coworkers in the LONE study who then contacted the older person with the question to participate in the study. Findings from the interviews with the older persons are presented elsewhere [31]. The older persons were asked, after their participation in an interview, if they had anyone that was close to them and that might agree to be interviewed. Their answers resulted in a list of 20 persons and 19 of them were interviewed (for a description of the sample, see Table 2). For this study, we

Table 1 Description of the older persons' care contexts, age, and gender

\begin{tabular}{ll}
\hline Older persons & $n=23$ \\
\hline Men/women & $12 / 11$ \\
Age, median (range) & $85(76-101)$ \\
Care context & $n=6$ \\
Primary health care centre & 2 \\
Municipal home care & 4 \\
Residential care & 8 \\
Hospital & 2 \\
Specialised palliative home care & 6 \\
Specialised palliative ward & 1 \\
\hline
\end{tabular}

Table 2 Description of the sample

\begin{tabular}{ll}
\hline Informants & $n=19$ \\
\hline Men/women & $6 / 13$ \\
Age, median (range) & $63(49-86)$ \\
Sons/daughters & $5 / 4$ \\
Brother & 1 \\
Friend & 1 \\
Daughter-in-law & 1 \\
Wives & 4 \\
Cousin's wife & 1 \\
Nieces & 2 \\
\hline
\end{tabular}

chose to use the concept "significant other" to designate the informants. It was the older persons who identified whom they wanted us to interview, and regardless of whom they named - friend, wife, daughter, etc. - the intrinsic meaning was the same, namely, a person who was close to them. In the following results, all the informants are referred to as "significant others." If the older person gave the name of a significant other, that name was communicated (together with a telephone number) to HL (the first author). The significant other was contacted by telephone by HL, who inquired whether s/he would accept to receive a letter with information about the study. The letter contained information about the ethical aspects of the study and a description of EL, referred to as a deeper sense of loneliness. A couple of days after the letter had been sent out, the significant other was contacted again by telephone and asked whether $s$ /he wanted to participate. If the significant other agreed to participate, $\mathrm{s} /$ he chose the time and the place for the interview. All the persons contacted, except one, wanted to participate.

\section{Procedure}

In eighteen interviews, nineteen significant others were interviewed. The interviews were individual, except one which was done with a couple. The informants received oral and written information about the aim of the study and about the procedure, together with a guarantee of confidentiality. They all gave both written and oral consent to participate. The interviewees all characterised their relation to the older person as close or very close. None of them were primary carers. The nature of the interviews was narrative. They followed a semi-structured guide with open-ended questions (see Additional file 1, for the Interview Guide), and were recorded digitally and then transcribed verbatim. The interviews lasted between 40 and $90 \mathrm{~min}$ (median $=51 \mathrm{~min}$ ) and were conducted from February 2015 until August 2016. All interviews were done by $\mathrm{HL}$, for the main part of the interviews with a senior researcher at her side. The 
interviews began by HL asking the informants to say something about the older person's situation. Then the informants were introduced to the concept of EL as follows: "We are, in particular, interested in a deeper feeling of being alone in life, sometimes referred to as existential loneliness, a feeling that can come and go. Can you try to remember any situation when you perceived that your ... experienced this kind of loneliness, this deeper feeling of being alone?" Follow-up questions were used when something came up that we thought was related to EL, questions such as "How did you notice EL?", "Could you please tell me a little bit more about that?", and "How would you put that feeling into words?"

\section{Data analysis}

Hsieh and Shannon [30] describe three approaches to content analysis. One of those approaches, the one chosen for this study, is referred to as conventional and is characterised by staying close to the text in order to get familiarised with it and let categories emerge directly from the data [30]. Thus, firstly, all transcribed material was read and reread to get a sense of the text, and when something came up related to the aim, this was noted. The notes were written down and led to two further questions: "What kind of situations seem to trigger EL?" and "In what ways is EL expressed?" Secondly, the transcribed material was gone through word by word with those two questions in mind, and meaning units were identified related to the aim. Thirdly, each meaning unit was condensed and given a code, still close to the actual text. In the fourth step, the interpretation started and each code was given an interpretation. In the fifth and last step, the interpretations were brought together in clusters based on how they were related to each other. This step resulted in three categories that answer the question "As interpreted by the significant others, what circumstances seem to give rise to EL among older persons?": Being limited in body and space, Being in a process of disconnecting, and Being disconnected from the outside world. All of the steps in the analysis were performed at first separately by the three authors and then together, comparing codes and interpretations until an agreement was reached.

\section{Results}

\section{Being limited in body and space}

The category Being limited in body and space illustrates how, according to significant others, limitations in frail older peoples' lives lead to dependence on others. The limitations that they refer to are physical impairments in body and decreasing mobility in space. The decreasing mobility in space makes it difficult or impossible for older people to choose or decide for themselves where to be. When physical changes make older people incapable of deciding over their own body, they become increasingly dependent on staff and significant others. According to the significant others, the lack of personal freedom gives rise to EL. The body becomes a barrier to freedom and independence. In the example below, a significant other describes certain physical impairments that trigger EL. The older person who previously had been a very strong and vigorous man is now dependent on others for help with his most intimate needs.

He says like, 'if I could just use my hand, he says, 'that's the worst of it all, this hand'//... and the incontinence and that he can't...it's the worst thing he knows. To have to rely on other people and to use diapers and all that, ugh, he thinks it's horrible... he can't do anything...//he says, 'I'm totally worthless'... he also says that he's pitiful...//...he wants to manage by himself...but he can't (21a)

According to significant others, the limitations of the body also affect the older person's self-image. The dependence on others, as well as their inability to choose for themselves, give rise to certain feelings that older people have difficulties expressing to their significant others. The significant others refer to narratives where older persons say that they "see themselves as worthless," and they also refer to situations where older persons use degrading words about themselves and show frustration. The significant others interpret these expressions of worthlessness and frustration as manifestations of EL due to older people's increasing physical impairments.

...it wasn't funny many times... to hear 'I don't want to live anymore, that 'this isn't a life worth living'...the impact of diseases and things like that, that she didn't have the ability to move and participate any longer, it's made her frustrated...//...we've always been doing things together, she's been with us skiing in Austria and swimming in Germany and Belgium and we've been bicycling in the forest... and always been very active and all of a sudden not being able to move and be with us and be active...//... all of her life, now it's not possible any more, 'now I can hardly move, it's not a life worth living'...// (8a)

According to significant others, reduced mobility in space sometimes means lack of freedom. They perceive that EL arises when older persons can no longer decide in what place they want to be, and when they no longer have the ability to move between different environments. One example of this is an older person who earlier in life travelled a lot and through life has had different kinds of 
jobs which took him to many different places. As a disabled man he can still have some freedom driving around in his motorised wheelchair, but when he cannot use his motorised wheelchair any more he becomes dependent on other people and his personal freedom decreases because of his limitations in space.

\section{...he loves his motorised wheelchair and it's been a feeling of freedom, he's been driving out, down to the harbour, and he's bought ice cream and he's been looking around for a while, and when he no longer has this ability you notice that he thinks it's very sad...//... this feeling of freedom, to look around, get impressions and experiences, decide yourself, maybe have control over what you...you decide yourself, now I want to go out and you do that, not being dependent on someone else...// (4a)}

In summary, when older people are no longer able to move around and choose for themselves where to go, they become limited in their spatial freedom and this may lead to EL. Being limited in body and space thus seems to give rise to EL, as interpreted by significant others.

\section{Being in a process of disconnecting}

The category Being in a process of disconnecting illustrates how, according to significant others, frail older persons are in a continuous process of losing other people, places, and material belongings that they are or have been attached to. The many losses make older peoples' lives empty and this may give rise to EL. The continuity in the older persons' relationship to friends is often broken and they find it difficult to fill the gap. Saddened by this, they often think about people who have been important to them through life and especially their long-term relationships. The broken ties have to do not only with the fact that their friends get old and die, but also with difficulties in maintaining a relationship. This leads to emptiness since there is no longer anyone to share life with. Such a loss of emotional ties also means losing a part of themselves, as the person or persons they have lost cannot be replaced. The quote below illustrates a significant other's description of the older person's many losses.

...who [an acquaintance] also passed away, unfortunately//So the two of them... became friends and they met a lot... Then she died too...Sad. It's, it's sad, so now she hasn't got anyone...not any real friend//...they are fading away//And yes...since dad died...she's sad of course//...that's... when...that's when she was left alone...lonesome...they had...lived all of their life together...and...yes, I think that...that they needed each other...to somehow fill out their lives in some way...// (22a)
Older persons' EL also seems to relate to the loss of their connection to cherished material belongings. According to the significant others, it is an emotional process of anxiety and melancholy for the older persons to know that they will have to let go of objects from their past that have a special value for them, or to imagine that those objects will not have any importance for anyone else after their death. To let go of one's attachment to material belongings means to lose a part of oneself, which may lead to EL. Significant others have the impression that older persons are aware that the end of life is approaching, and to talk about their belongings becomes a way to pass on the story of their life. One example is a significant other who describes how the older person wants to tell the story of her life by talking about the objects connected to her past that have been important for her.

\section{...she tells a lot about her life too, she's very keen to somehow pass things on, she tells me//she's keen for me to know that this tapestry, for example, was made by her aunt, I notice it, she...it troubles her a bit, I think, that when she's gone, the things will be dispersed in a sale, you know, and no one knows about her memory- laden things. She talks a lot about those things...she anchors her history in some way// (1b)}

The older person's life story can also be related to a certain place. As interpreted by significant others, the process of losing the connection to a certain place leads to EL. The significant others notice expressions of sadness and grief among older people who look back on certain places of importance that they no longer have contact with. One example of this is a significant other who recounts how an older person was unable to stay in his house in the countryside where he wanted to live and dreamt of living until the end.

....he always gets...he's very sad when he returns from there, always, always...//Because he wants to be there, he's...well, he...we've lived in many places and he's renovated houses here and there and apartments and he's...but he's never been so attached to anything before this place...//He thought we would live for the rest of our lives at that place... but it didn't turn out like that//...there are many losses...that he thinks about// (21a)

The many and continuous losses make EL surface among older people. When they are in the process of looking back on painful memories, this is especially evident. The significant others feel that the memories often have to do with things in life that the older person wishes had turned out differently, but that are now too 
late to change. These memories are often filled with regret over a choice in life that was wrong or with sadness that different choices were not possible to make. The significant others describe how they notice that this mood is painful for the older person and that it triggers EL and is expressed as regret and as an inability to feel inner peace.

She hasn't got...she hasn't...she hasn't got inner peace, she hasn't lived the life she wished for, she's lived a life where she's been... well, in...not forced to, probably not, but the choices she's made have led to a life that she didn't choose...(5b)

In summary, the significant others perceive that older persons are in the process of continuously losing their connection to other people, places, and material belongings that they are or have been attached to, and that they find it hard to fill the gap left by those losses. This process leads to an increasing emptiness and makes older people experience EL. Being in a process of disconnecting thus seems to give rise to EL, as interpreted by significant others.

\section{Being disconnected from the outside world}

The category Being disconnected from the outside world illustrates how, according to their significant others, frail older persons no longer have a sense of being part of a community, but rather are in a state of alienation, which makes their lives lonesome and gives rise to feelings of meaninglessness. One illustration of this is shown in the quotation below, where a significant other tells of an older person, living at a nursing home, who feels no companionship in the context she lives in because the other people living at the same nursing home are not able to talk or connect with each other at the dinner table. The significant other describes how the older person's life becomes disconnected and how this seems to trigger EL.

... and I mean the meals...sure, it's good that they are gathered, but I mean there are...I think there are eight residents... and I think that half of them have to be fed... and of course, to be ninety-five years old and have to confront this, it can't be only positive//...she thinks there's no one else... and there isn't anyone else, more than her, at the unit who has a clear mind, as she does...// (11a)

Significant others perceive that older persons have difficulties in communicating their disconnection, but that they try to find words that explain how they feel. Below, a significant other relates what an older person has said, which she understands as if the older person describes disconnection. The older person seems to voice EL by saying that the days have become quiet and silent.

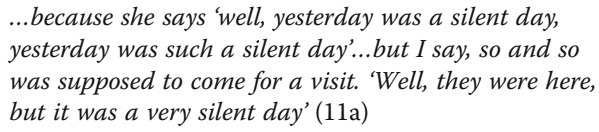

Several of the significant others feel that they can tell just by looking at the older person that $\mathrm{s} /$ he is disconnecting. According to significant others, the disconnection from the outside world is seen regardless of where the older person lives. Sometimes they feel that they have trouble connecting with the older person, who increasingly turns off the outside world and withdraws into him- or herself. The significant others, also point out that it is not always easy to understand the older person's expressions of disconnection, and they recount how although the older persons do not always describe their situation with words they nevertheless do so with their body language. Below, a significant other describes how the older person shows with her body that she has turned off the outside world.

...then she's sitting like this, in this way [hanging over the table], I usually say that it's like a computer that stalls...that's shutting down, and that's how my mom sits $(14 \mathrm{a})$

Older persons often have difficulties putting their experiences of disconnection and meaninglessness into words. However, on hearing expressions like "There's no meaning any more," the significant others sometimes think that the older persons experience disconnection. The significant others understand these words as if the older persons feel that their lives have nothing more to give, and as a longing for life to end, that is, as a longing to die. In summary, when life becomes increasingly disconnected from the outside world and meaningless for older people, they experience EL. Feelings of being disconnected thus seem to give rise to EL, as interpreted by significant others.

\section{Discussion}

The result of this study shows that the significant others perceive that the older persons experience EL (1) when they are increasingly limited in body and space, (2) when they are in a process of disconnecting, and (3) when they are disconnected from the outside world. The comprehensive understanding of the result is that the older person is in a process of letting go of life.

A key finding is that the significant others perceive that the older persons' physical impairments lead to EL. There is plenty of research concerning professionals' 
experiences of meeting older persons' existential needs $[7,8,16]$ but only one study that relates existential challenges to the physical body [16]. A study by Whitaker [32] describes older persons' experiences of the body as a constant reminder of the finitude of life, and a similar result is shown in research related to palliative care [16]. The idea of the deteriorating body can be related to Gabriel Marcel, according to whom an existential situation can be described as a trial when we, in our body, confront time [33]. In the present study, this is illustrated by the decay of the physical body as experienced by older people. One experience in the trial that Marcel talks of could be EL. In order to notice, recognise, and be able to interpret the older person's bodily expressions, it is of importance to know the person well [19], as significant others often do. However, studies have shown that the situation of significant others is complex $[22,24,34]$ and that the health care system fails to take advantage of their knowledge of the older person's situation $[9,10]$. Thus, the knowledge that the significant others' possess, regarding for example the older persons' bodily expressions, may never reach the health care professionals. This study demonstrates that significant others are a valuable resource in the understanding of the experience of EL.

Another key finding is that the significant others perceive that the older persons experience EL when they increasingly lose long-term relationships, either through an inability to maintain contact or through bereavement. Often, the older persons' ability to communicate in social situations is also reduced. The significant others notice this and perceive that, as a result, EL surfaces among older persons. This finding can be related to a study that highlights experiences of aphasia [17]. Nyström's interview study [17] concludes that without a communicative relational anchor, EL will occur. Furthermore, the importance of relations is emphasised by Marcel, who writes that the meaning of life is about the meeting between you and me [33]. If we as human beings do not have, or are unable to maintain, relationships, the meaning of life will be lost. When older persons are no longer capable of maintaining social contacts, the health care professionals become a vicarious relational anchor in their existence. However, several of the significant others talk about the fact that the older persons' health care contact is not enough to fulfil their need for a relational anchor. Martin Buber claims that it is of importance to have I and you relations in order for a fruitful meeting to occur [35]. Such relationships usually exist between the older person and a person they refer to as their significant other. An approach that may enable an $I$ and you relation between professionals and the older person is person-centred care. During the last few years, person-centred care has been favoured in several health care settings of Western societies and its philosophy is to focus on what is important for the person that receives care. In order to know something about what is important for a person, it is essential to build a relationship over time, which requires a certain continuity [36]. Several studies show that one of the greatest challenges to person-centred care is the increased time pressure and stress $[36,37]$ that reduce the opportunities for building a relationship and that are difficult to reconcile with the older person's existential needs, which require genuine presence [17]. However, encountering the older person and his/her significant others, being able to sit down and talk for a while in a supporting care environment where the personnel feel encouraged and supported by each other and by the organisation, are examples of conditions that make a person-centred philosophy flourish in elderly care [36]. This study shows that significant others feel that the older person can experience EL even in a social context, and that there is a need to further explore the impact of the absence of relational anchorage on EL in older persons.

Finally, yet another key finding is that significant others perceive that the older person is increasingly dependent on others. This finding can be related to a lack of autonomy, because the older persons' ability to make choices and influence their situation is significantly reduced. Freedom of choice and freedom to influence one's own life are important aspects of autonomy. Another aspect of autonomy is the ability to influence, and to interact with, one's environment [38]. Studies dealing specifically with autonomy linked to older people are sparse. Thus, it is difficult to know how older people experience their situation of dependence. In a concept analysis, four Swedish researchers show that there is a discrepancy between what is said about how autonomy should be safeguarded and how patients experience autonomy [38]. There are, however, few studies describing freedom in the context of EL. In a few previous studies, the situation of older people with reduced opportunities to choose, and to influence their own lives, is described as if a limit in life is reached [16, 32], which is likely to involve experiences of limited freedom. The link between the lack of freedom and EL can be seen in relation to Frankl's contention that freedom consists of the possibility to choose [15]. Thus, if we as humans do not experience the freedom to choose, life has reached a limit. The significant others describe how they notice that the older person increasingly turns off the outside world and withdraws into him- or herself. According to the present study, this can be understood as if the older person withdraws in an attempt to seek inner peace, that is, a kind of inner freedom, when outer freedom is no longer possible. Buber [35] describes this state as a process of 
thinking, which can be seen as each person's inner conversation with him- or herself, and this inner freedom cannot be taken away from anyone.

In summary, the result of this study is consistent with previous research that has shown that EL is a complex phenomenon. In addition, this study highlights the interpretations of significant others and shows that their experiences are valuable to take into account in order to understand EL among frail older people. Nevertheless, research demonstrates that significant others are excluded $[10,24]$ when they should be seen as a resource in the care of older people [9, 24, 25].

There are some limitations to this study. First, the study took place within a context of a Western society where loneliness is seen as a sensitive topic to talk about [16] and we had only one informant with an origin other than Western. In addition, the fact that we interviewed significant others of frail older persons in need of long-term care might have given the first category, Being limited in body and space, a greater significance than it would have had if the informants had been significant others of older people in general. These limitations potentially reduce the transferability [39] of the findings. Furthermore, we had to take into consideration that the concept of EL is not clarified and is seen as a complex phenomenon. Therefore, we were two interviewers, one junior researcher and one senior researcher familiar with existential conversations, so that one of us could have the role of an observer, making notes and at the end of the interview adding some more questions, if needed. Finally, to guarantee the dependability [39] of this study it was important to minimise the risk of basing interpretations on preunderstandings, and therefore all three researchers took part in the analysis and the interpretations. Furthermore, in order for the interpretations of the researchers to be verifiable [39], the reader of this study should be able to follow every step, and to this end quotations are used to exemplify the three categories that emerged during the analysis process.

\section{Conclusion}

The implications of this research include a deepened understanding of EL. The result can be understood as if the older person is in a process of letting go of life. This process involves the body, in that the older person is increasingly limited in his or her physical abilities. The older person's long-term relationships are gradually lost, and finally the process results in the older person increasingly withdrawing into him- or herself and turning off the outside world. What we can say is that these findings seem to be central to the experience of EL among frail older persons, as interpreted by their significant others. However, what we cannot say anything about is whether the findings reflect the older persons' actual experience. Therefore, comparing the older persons' experience with the perception of their significant others' is an important topic for further research.

\section{Additional file}

Additional file 1: Interview Guide (developed for this study; not previously published). (DOCX $13 \mathrm{~kb}$ )

\section{Abbreviation}

EL: Existential loneliness; HL: Helena Larsson; IB: Ingrid Bolmsjö; MR: Margareta Rämgård

\section{Acknowledgements}

We are most grateful to the interviewees for sharing their experiences and to Anna-Karin Edberg for constructive comments on the manuscript and to Katarina Graah-Hagelbäck for language revision.

\section{Funding}

This study is a part of the LONE project, funded by grants from the Vårdal Foundation and the Research Platform for Collaboration for Health at Kristianstad University for contribution concerning funding of involved researchers, the Crafoord Foundation and the Greta and Johan Kock Foundation for financial contribution to design and data collection, and the Gyllenstiernska Krapperup Foundation for contribution concerning financing of research meetings.

\section{Availability of data and materials}

According to current national legislation, ethical review boards in Sweden do not allow public sharing of sensitive raw data but are available from the corresponding author on reasonable request. However, all raw data is in Swedish. Extracts from the interviews have been translated and are part of the results, and pseudonyms have been used.

\section{Authors' contributions}

Each author of this manuscript made a substantial contribution to this work and meets the criteria for authorship as noted in the editorial policy statement of BMC Geriatrics. HL, MR and IB designed the study and carried out the interviews. $\mathrm{HL}, \mathrm{MR}$ and $\mathrm{IB}$ participated in the analysis and interpretation of data. All three authors read and approved the final manuscript, and agree to be accountable for all aspects of the work in ensuring that questions related to the accuracy or integrity of any part of the work are appropriately investigated and resolved.

\section{Ethics approval and consent to participate}

The study was approved by the Ethical Review Board, Lund, Sweden (reg.no. 2014/652). The informants received oral and written information about the aim of the study and about the procedure, together with a guarantee of confidentiality. They all gave both written and oral consent to participate. It was made clear to the informants that they could withdraw from the study at any time. They were also informed that their participation or their withdrawal would not affect the care of the older person in any manner. Informed consent for participation and permission to audiotape the interview were obtained from the informants after a description of the study by the first author.

\section{Consent for publication}

Non-applicable.

\section{Competing interests}

The authors declare that they have no competing interests. 


\section{Publisher's Note}

Springer Nature remains neutral with regard to jurisdictional claims in published maps and institutional affiliations.

Received: 31 January 2017 Accepted: 4 July 2017

Published online: 10 July 2017

\section{References}

1. World Economic and Social Survey 2007: development in an ageing world New York: United Nations Department of Social and Economic affairs. 2007 Report No. E/2007/50/Rev.1ST/ESA/314. http:/www.un.org/en/ development/desa/policy/wess.pdf. Accessed 17 Apr 2017

2. WHO: World report on ageing and health. 2015. http://www.who.int/ ageing/events/world-report-2015-launch/en/ Accessed 9 Dec 2016

3. Greisinger AJ, Lorimor RJ, Aday LA, Winn RJ, Baile WF. Terminally ill cancer patients. Their most important concerns. Cancer Pract. 1997;5(3):147-54.

4. Albinsson L, Strang P. Existential concerns of families of late-stage dementia patients: questions of freedom, choices, isolation, death, and meaning. J Palliat Med. 2003;6(2):225-35.

5. Bolmsjö I. Existential issues in palliative care-interviews with cancer patients. J Palliat Care. 2000;16(2):20-4.

6. WHO: Definition of Palliative Care. 2014. http://www.who.int/cancer/ palliative/definition/en/ Accessed 9 Dec 2016

7. Beck I, Törnquist A, Broström L, Edberg AK. Having to focus on doing rather than being-nurse assistants' experience of palliative care in municipal residential care settings. Int J Nurs Stud. 2012;49(4):455-64.

8. Pessin H, Fenn N, Hendriksen E, DeRosa AP, Applebaum A. Existential distress among healthcare providers caring for patients at the end of life. Curr Opin Support Palliat Care. 2015;9(1):77-86.

9. Dyrstad DN, Laugaland KA, Storm M. An observational study of older patients' participation in hospital admission and discharge-exploring patient and next of kin perspectives. J Clin Nurs. 2015;24(11-12):1693-706.

10. Lowson E, Hanratty B, Holmes L, Addington-Hall J, Grande G, Payne S, Seymour J. From 'conductor' to 'second fiddle': older adult care recipients' perspectives on transitions in family caring at hospital admission. Int J Nurs Stud. 2013:50(9):1197-205.

11. Mayers AM, Svartberg M. Existential loneliness: a review of the concept, its psychosocial precipitants and psychotherapeutic implications for HIVinfected women. Br J Med Psychol. 2001;74(Pt 4):539-53.

12. Ettema EJ, Derksen LD, van Leeuwen E. Existential loneliness and end-of-life care: a systematic review. Theor Med Bioeth. 2010;31(2):141-69.

13. Yalom ID. Existential psychotherapy. New York: Basic Books; 1980

14. Tillich P. The courage to be. 3rd ed. New Haven and London: Yale University Press; 2000.

15. FrankI VE. Man's search for meaning: an introduction to logotherapy. London: Hodder and Stoughton; 1987.

16. Sand L, Strang P. Existential loneliness in a palliative home care setting. Palliat Med. 2006;9(6):1376-87.

17. Nyström M. Aphasia-an existential loneliness: a study on the loss of the world of symbols. Int J Qual Stud Health Well-being. 2006;1(1):38-49.

18. Norell Pejner $M$, Ziegert $K$, Kihlgren A. Older patients in Sweden and their experience of the emotional support received from the registered nurse - a grounded theory study. Aging Ment Health. 2015:19(1):79-85.

19. Abrahamsson K, Bernard B, Magnabosco L, Nazir A, Unroe KT. The experiences of family members in the nursing home to hospital transfer decision. BMC Geriatr. 2016:16:184

20. Blindheim K, Thorsnes SL, Brataas HV, Dahl BM. The role of next of kin of patients with cancer: learning to navigate unpredictable caregiving situations. J Clin Nurs. 2013;22(5-6):681-9.

21. Esbensen $B A$, Thomé $B$. Being next of kin to an elderly person with cancer. Scand J Caring Sci. 2010;24(4):648-54.

22. Munck B, Fridlund B, Martensson J. Next-of-kin caregivers in palliative home care-from control to loss of control. J Adv Nurs. 2008;64(6):578-86.

23. Funk L, Stajduhar K, Toye C, Aoun S, Grande G, Todd C. Part 2: home-based family caregiving at the end of life: a comprehensive review of published qualitative research (1998-2008). Palliat Med. 2010;24(6):594-607.

24. Andershed B. Significant others in end-of-life care - part 1: a systematic review of the literature the five last years, January 1999-February 2004. J Clin Nurs. 2006;15(9):1158-69.

25. Digby R, Bloomer MJ. Families and caregivers of older people: expectations, communication and care decisions. Collegian. 2014:21(4):345-51.
26. Fillit H, Butler RN. The frailty identity crisis. J Am Geriatr Soc 2009:57:348-52.

27. Edberg AK, Bolmsjö I: Study protocol: Exploring existential loneliness among frail older people. The development phase of the LONE study. 2017.

28. Medical Research Council. Developing and evaluating complex interventions: new guidance. London: Medical Research Council; 2008

29. Polit DF, Beck CT. Essentials of nursing research: appraising evidence for nursing practice. Philadelphia: Wolters Kluwer Health/Lippincott Williams \& Wilkins; 2013

30. Hsieh HF, Shannon SE. Three approaches to qualitative content analysis. Qual Health Res. 2005;15(9):1277-88.

31. Sjöberg M, Beck I, Rasmussen B, Edberg AK. Being disconnected from lifemeanings of existential loneliness as narrated by frail older people. Accepted for publication in Aging Ment Health June, 2017.

32. Whitaker A. The body as existential midpoint - the aging and dying body of nursing home residents. J Aging Stud. 2010;24(2):96-104

33. Marcel G, Schilpp PA, Hahn LE. The philosophy of Gabriel Marcel. 1st ed. La Salle: Open Court Pub. Co.; 1984

34. Wallerstedt B, Andershed B, Benzein E. Family members' caregiving situations in palliative home care when sitting service is received: the understanding of multiple realities. Palliat Support Care. 2014;12(6):425-37.

35. Buber M. I and thou. 2nd ed. T\&T Clark: Edinburgh; 1994

36. McCormack B, Dewing J, Breslin L, Coyne-Nevin A, Kennedy K, Manning M, Peelo-Kilroe L, Tobin C, Slater P. Developing person-centred practice: nursing outcomes arising from changes to the care environment in residential settings for older people. Int J Older People Nursing. 2010;5(2): 93-107.

37. Duffield C, Gardner G, Catling-Paull C. Nursing work and the use of nursing time. J Clin Nurs. 2008;17(24):3269-74.

38. Lindberg C, Fagerström C, Sivberg B, Willman A. Concept analysis: patient autonomy in a caring context. J Adv Nurs. 2014;70(10):2208-21.

39. Shenton AK. Strategies for ensuring trustworthiness in qualitative research projects. Educ Inf. 2004:22:63-75.

\section{Submit your next manuscript to BioMed Central and we will help you at every step:}

- We accept pre-submission inquiries

- Our selector tool helps you to find the most relevant journa

- We provide round the clock customer support

- Convenient online submission

- Thorough peer review

- Inclusion in PubMed and all major indexing services

- Maximum visibility for your research

Submit your manuscript at www.biomedcentral.com/submit
C BioMed Central 


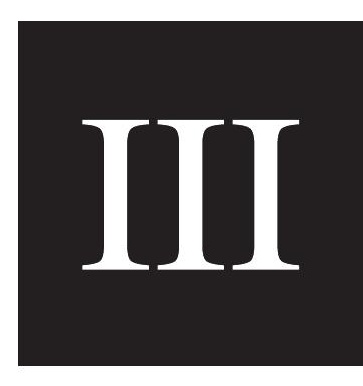




\title{
Contrasts in older persons' experiences and significant others' perceptions of existential loneliness
}

2019, Vol. 26(6) 1623-1637

(C) The Author(s) 2018

Article reuse guidelines: sagepub.com/journals-permissions

I0.1177/0969733018774828

journals.sagepub.com/home/nej

@SAGE

\section{Helena Larsson}

Malmö University, Sweden; Kristianstad University, Sweden

\author{
Anna-Karin Edberg \\ Kristianstad University, Sweden
}

\section{Ingrid Bolmsjö and Margareta Rämgård}

Malmö University, Sweden

\begin{abstract}
Background: As frail older people might have difficulties in expressing themselves, their needs are often interpreted by others, for example, by significant others, whose information health care staff often have to rely on. This, in turn, can put health care staff in ethically difficult situations, where they have to choose between alternative courses of action. One aspect that might be especially difficult to express is that of existential loneliness. We have only sparse knowledge about whether, and in what way, the views of frail older persons and their significant others concerning existential loneliness are in concordance.

Objective: To contrast frail older ( $>75)$ persons' experiences with their significant others' perceptions of existential loneliness.

Methods: A case study design was chosen for this study. Individual interviews with frail older persons $(n=15)$ and interviews with their significant others $(n=19)$, as well as field notes, served as a basis for the study. A thematic analysis was used to interpret data.

Ethical considerations: This study was conducted in accordance with the principles of research ethics. Findings: The findings showed three themes: (I) Meaningless waiting in contrast to lack of activities, (2) Longing for a deeper connectedness in contrast to not participating in a social environment and (3) Restricted freedom in contrast to given up on life.

Discussion: Knowledge about the tensions between older persons' and their significant others' views of existential loneliness could be of use as a basis for ethical reflections on the care of older people and in the encounter with their significant others.

Conclusion: It is of importance that health care professionals listen to both the frail older person and their significant other(s) and be aware of whose voice that the care given is based on, in order to provide care that is beneficial and not to the detriment of the older person.
\end{abstract}

\section{Keywords}

case study, existential loneliness, frail older person, significant other, thematic analysis

Corresponding author: Helena Larsson, Faculty of Health Sciences, Kristianstad University, SE-29I 88 Kristianstad, Sweden. Email: helena.larsson@hkr.se 


\section{Introduction}

As frail older people might have difficulties in expressing themselves, their needs and symptoms often have to be interpreted by others. One such, and subtle, issue is that of existential loneliness, which is difficult to interpret and detect. Significant others, such as family and friends, are frequently described as important advisors ${ }^{1}$ and decision-makers ${ }^{1-3}$ and health care staff often need to rely on their information. It is, of course, of great importance to involve and listen to significant others, ${ }^{4-6}$ but if their view differs from that of the older person, it can put health care staff in ethically difficult situations, where they have to choose between alternative courses of action. ${ }^{7}$ We have, however, only sparse knowledge about whether, and in what way, significant others' and older people's views of existential loneliness are in concordance. Such knowledge can be highly important for care provision, not only in the case of existential loneliness as such but also from a wider perspective concerning the weight that health care professionals give to information from different sources.

Paul Tillich ${ }^{8}$ and Viktor Frankl ${ }^{9}$ describe an existential dimension of loneliness as a phenomenon that belongs to life. ${ }^{10}$ Furthermore, the psychotherapist Irvin Yalom, ${ }^{10}$ who has explored existential concerns in human beings' lives, has referred to existential loneliness as a stipulation of life and pointed to how life itself involves existential loneliness. He describes what he calls 'the ultimate concerns', such as the inevitability of death, our need of freedom and belongingness and our search for meaning,${ }^{10}$ which are all connected to existential loneliness, sometimes referred to as existential isolation, ${ }^{10}$ existential anxiety ${ }^{8}$ or existential distress. ${ }^{9,11}$ More recently, existential loneliness has been explored in two reviews and described as a complex and unclear phenomenon. ${ }^{12,13}$ The literature review by Mayers and Svartberg ${ }^{12}$ describes existential loneliness as a basic sense of loneliness that occurs when we, as human beings, face that we are separated and alone in the world despite having other people around. The other review concludes existential loneliness as a fundamental condition of human life, intertwined with feelings of nothingness and emptiness. ${ }^{13}$ In addition, existential loneliness has been empirically studied in different health care contexts, for example, in palliative care ${ }^{14}$ in the care of people with aphasia, ${ }^{15}$ among women living with HIV,${ }^{12}$ and among frail older people ${ }^{16}$ and their significant others. ${ }^{17}$ One part of life when existential issues seem especially evident is in old age when thoughts like 'life is completed and no longer worth living' come to the fore, ${ }^{18}$ as well as thoughts of death and dying, ${ }^{19}$ and such experiences relate to existential loneliness. ${ }^{14}$ Frail older people have described existential loneliness as being related to feeling trapped in a frail and deteriorating body, being met with indifference, having nobody to share life with, and lacking purpose and meaning ${ }^{16}$ while their significant others have described the older person's existential loneliness in terms of being disconnected from the outside world. ${ }^{17}$ One conclusion that can be drawn from these studies is that existential loneliness is a phenomenon that involves a range of feelings and expressions that might be interpreted differently by different people.

In the care of frail older people, significant others often have to act as representatives for the older person at the end of life. ${ }^{1}$ They can also function as an important link between the older person's former and present situation. ${ }^{4}$ However, an interview study with family members concluded that there is an underlying risk that they often, instead of listening to the older person's own wants and wishes, make decisions based upon trust, type of relationship and available information, which can all be influenced by the caring culture and the communication in the family. ${ }^{2}$ In addition, health care staff have to navigate between the older person, their significant other(s), the organisation, laws and not least their own moral and ethical approach ${ }^{20}$ to do good and not harm. ${ }^{21}$ This is not an easy task, especially when facing such an unclear and complex phenomenon as existential loneliness. Studies have shown that health professionals find it challenging to encounter existential distress among persons with advanced cancer ${ }^{11}$ and existential loneliness among frail older persons. ${ }^{22}$ Furthermore, studies show that health care staff provide care based upon what they believe is best for the patient, sometimes without even asking the patient. ${ }^{3}$ This also becomes visible in results from 
studies using proxy ratings, that is, when someone else, for example, significant others or health care staff, rates the patient's symptoms. Studies focusing on comparisons of self- and proxy assessments of pain ${ }^{23}$ and proxy ratings of quality of life among patients with dementia ${ }^{24}$ show that the ratings differ and that even people who state that they know the older person well do not really know him or her. There is, therefore, a need for a deeper understanding of these differences in order to guide health care professionals in the provision of care.

The present study has its starting point in two previous studies from the existential loneliness study (LONE study). ${ }^{25}$ The LONE study is on the development phase of a complex intervention, ${ }^{26}$ where existential loneliness is explored through interviews with frail older people, ${ }^{16}$ their significant others, ${ }^{17}$ and health care staff. ${ }^{22}$ The aim of this study was to contrast frail older $(>75)$ persons' experiences with their significant others' perceptions of existential loneliness.

\section{Methods and material}

\section{Design}

The present study has its starting point in two previous studies, one with frail older persons' experiences of existential loneliness ${ }^{16}$ and the other regarding significant others' interpretations of the older person's existential loneliness. ${ }^{17}$ Since the two first studies focused on experiences and perceptions, respectively, and this study aimed to explore contrasts, we used an inductive approach in a secondary analysis of these interviews. A case study design was chosen since the intention was to present a complete description of the phenomenon within its social context and answer the questions of 'how' and 'why'. ${ }^{27}$ Individual interviews with frail older persons and interviews with their significant others, as well as field notes, served as a basis for analysis. Since a case study is a method for structure rather than a method for analysis, ${ }^{27}$ a thematic analysis $^{28}$ served as a tool to interpret the data. The thematic analysis made it possible to search for themes and patterns in the data and to contrast experiences and perceptions.

\section{Setting}

The concept 'frail older people' was defined as older $(>75)$ persons, late in life and dependent on long-term care or services related to health problems. The word 'frail' relates in this study, as well as in the LONE study, ${ }^{25}$ to a frail physical body due to illness and physical impairments. The care was given by formal caregivers from the municipality or the county council. In order to attain variation, persons from different care contexts were interviewed: Primary health care centre, Municipal home care, Residential care, Hospital, Specialised palliative home care and Specialised palliative ward. Data were collected in the southern part of Sweden.

\section{Data collection}

Three separate data collections served as a basis for this case study: individual interviews with frail older people $(n=15)$, interviews with one or more of their significant others $(n=19)$ and the researchers' field notes from the interviews with the older persons. Saturation was reached when the researchers who did the interviews assessed that nothing additional of relevance for the study came up in the interviews. In total, 23 older persons were interviewed. ${ }^{16}$ Since the aim of this study was to contrast experiences and perceptions, it was necessary to use paired interviews which consisted of one older person and his or her significant others. Therefore, it was only possible to use 15 of the 23 interviews with the older persons since they were the ones who had designated a significant other. 
Table I. Characteristics of the sample.

\begin{tabular}{lc}
\hline Older persons & $n=15$ \\
\hline Men/women & $7 / 8$ \\
Age: median (range) & $86(76-10 \mathrm{I})$ \\
Care context & \\
$\quad$ Primary health care centre & 4 \\
$\quad$ Municipal home care & 2 \\
Residential care & 4 \\
Hospital & $\mathrm{I}$ \\
Specialised palliative ward & $\mathrm{I}$ \\
Specialised palliative home care & 3 \\
Living in ordinary housing & $1 \mathrm{I}$ \\
Living in a nursing home & 4 \\
\hline Significant others & $\mathrm{n}=19$ \\
\hline Men/women & $6 / 13$ \\
Age: median (range) & $(49-86)$ \\
Sons/daughters & $5 / 4$ \\
Sibling & $\mathrm{I}$ \\
Friend & $\mathrm{I}$ \\
Daughter-in-law & $\mathrm{I}$ \\
Wives & 4 \\
Cousin's wife & $\mathrm{I}$ \\
Nieces & 2 \\
\hline
\end{tabular}

Interviews with older persons. The older persons were identified by a designated contact person at each care unit who provided oral and written information about the study. If the older person gave his or her permission, his or her name was communicated to one of the co-workers who contacted the older person, asking him or her whether he or she wanted to participate in the study. Among the older persons, seven were men and eight were women, aged 76-101 years (median $=86$ years). For a description of the sample, see Table 1.

The interviews lasted between 46 and $147 \mathrm{~min}$ (median = $72 \mathrm{~min}$ ) and were conducted between February 2015 and July 2016. The interviews were of a narrative nature, and after an initial conversation about who we were and why we were there, the informants were asked about their experiences of loneliness in general. Thereafter, the concept of existential loneliness was introduced as follows:

We are particularly interested in your experiences of a deeper feeling of loneliness, called existential loneliness, a feeling that can come and go and be more or less intense. Could you please describe a situation when you experienced existential loneliness?

The older persons were interviewed by researchers other than the authors of this article, within the LONE study team. For a more detailed description of the interviews, see Sjöberg et al. ${ }^{16}$

Interviews with significant others. In connection with the interview, the older persons were asked if they had anyone who was close to them and who might agree to be interviewed. If the older person gave the name of a significant other, that name was communicated to H.L. (the first author). The significant other was then contacted by telephone by H.L., who inquired whether he or she would agree to receive a letter with 
information about the study. A couple of days after the letter had been sent out, the significant other was contacted again by telephone and asked whether he or she wanted to participate. Four of the older persons gave names of two significant others while 11 of the older persons gave only one name of a significant other. Altogether, 20 significant others were identified and asked to participate; 1 declined, which resulted in 19 persons agreeing to participate. All the significant others characterised their relation to the older person as close or very close. The interviews were individual, except one that was done with a couple. Among the significant others, 6 were men and 13 were women, aged 49-86 years (median $=63$ years). The interviews lasted between 40 and $90 \mathrm{~min}($ median $=51 \mathrm{~min})$ and were conducted between February 2015 and August 2016. For a description of the sample, see Table 1. The interviews were of a narrative nature, and after an initial conversation about loneliness in general, the concept of existential loneliness was introduced as follows: 'We are, in particular, interested in a deeper feeling of loneliness, called existential loneliness, a feeling that can come and go. Can you try to remember any situation when you perceived that your ... experienced this kind of loneliness?' For a more detailed description of the interviews, see Larsson et al. ${ }^{17}$

Field notes. According to Yin, ${ }^{27}$ a case study is interested in how a phenomenon is revealed in its context and therefore the field notes were important. After each interview with the older persons, field notes were taken by the researchers who did the interviews. The field notes were important in order to understand the context and focused on three aspects: (1) the physical environment such as living in older houses with high ceilings close to the city centre, smaller houses in the countryside or in a nursing home where material belongings bore witness of another life; (2) the atmosphere during the interview, such as if they wanted us to have some coffee, had laid the table with their finest china or merely wanted to talk to us; and (3) the researcher's thoughts and impressions of the interview situation, such as whether the older persons found it difficult to make their voice heard or to find words to express their experiences.

\section{Analysis}

In accordance with Yin, ${ }^{27}$ the next step was to select cases. In this study, a case was composed of the narratives of one older person, his or her significant other(s) and the field notes. The following step was to design a protocol ${ }^{27}$ that focused on contrasts in experiences and perceptions of existential loneliness. Thus, the interviews with the older persons, the interviews with their significant others and the field notes were read as a unit. Each of the older persons' and their significant others' narratives and the field notes was condensed into a reduced narrative with focus on the older person's context and on his or her experiences of existential loneliness, and significant others' perception of the same. This procedure resulted in 15 constructed narratives totalling about 40 pages.

The 15 constructed narratives were analysed using Braun and Clarke's ${ }^{28}$ guide as follows. The narratives were read repeatedly in order to become familiar with the text. This step was done independently by the four authors, who then came together to compare and contrast their impressions of the text. This was followed by the first author coding meaning units in the text that were related to the aim. The codes were thereafter discussed among the authors until agreement was reached and grouped into themes. The analysis moved back and forward between the 15 constructed narratives, cross-case conclusions and the three themes. For an example of meaning units and themes, see Table 2. The themes can be seen, according to Yin, ${ }^{27}$ as drawing cross-case conclusions. Based on the three themes, three new cross-case narratives were constructed to illustrate the contrast between older people's experiences and their significant others' perceptions of existential loneliness. An illustration of the procedure in the analysis is presented in Figure 1. 
Table 2. Extracts from raw data to exemplify the themes.

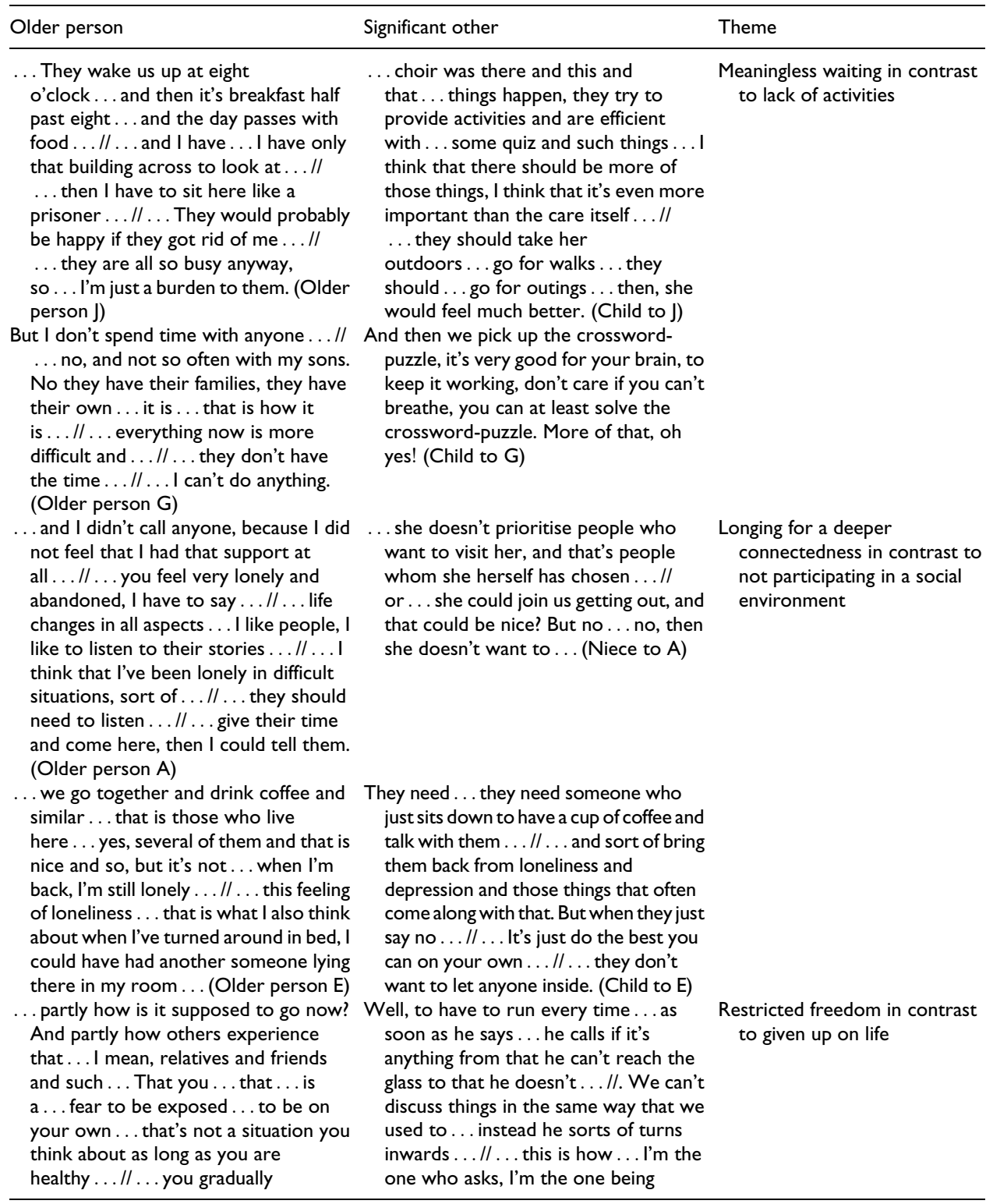

(continued) 
Table 2. (continued)

\begin{tabular}{|c|c|}
\hline Older person & Significant other \\
\hline $\begin{array}{l}\text { experience it, you sort of feel after a } \\
\text { year or so... before I could do that } \\
\text { very well, but now it's deteriorating, } \\
\text { and that results in that you gradually } \\
\text { maybe experience this loneliness } \\
\text { differently... I/... To not ... be able } \\
\text { to participate in the daily life. (Older } \\
\text { person F) }\end{array}$ & $\begin{array}{l}\text { active ...// ... he doesn't take any } \\
\text { initiatives by himself ...// ... but come } \\
\text { on, you have to. (Partner to } \mathrm{F} \text { ) }\end{array}$ \\
\hline 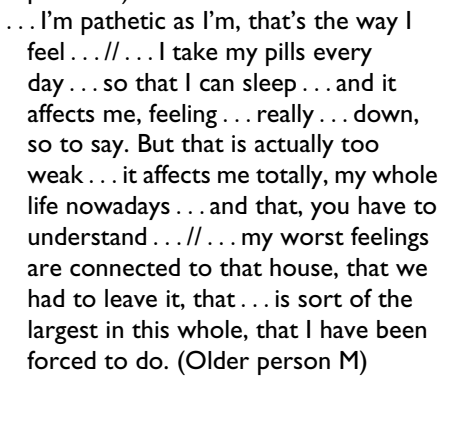 & $\begin{array}{l}\text { He's a bit lazy when it comes to exercise, } \\
\text { so I tell him, sometimes I say that he } \\
\text { needs to exercise his arms ... but it's } \\
\text { difficult, so we keep on anyway and I } \\
\text { say that you have to understand that, } \\
\text { that our goal is that you should be able } \\
\text { to get out of bed every morning and } \\
\text { not remain in bed, but to be up and get } \\
\text { dressed, even if you just sit in the } \\
\text { wheel-chair, that is what we need to } \\
\text { aim at. And I nag at him, now you have } \\
\text { to, you see... and pull his arms, but he } \\
\text { actually should be able to do much } \\
\text { more. (Sibling to M) }\end{array}$ \\
\hline
\end{tabular}

\section{Ethical approval and consent to participate}

The study was performed in accordance with the ethical guidelines by Helsinki Declarations ${ }^{29}$ and approved by the Ethical Review Board, Lund, Sweden (Reg. no. 2014/652). The informants, both the older persons and their significant others, received oral and written information about the aim of the study and about the procedure, together with a guarantee of confidentiality. They all gave both verbal and written consent to participate. It was made clear to the informants that they could withdraw from the study at any time and they were informed that their participation or their withdrawal would not affect the care in any manner. A risk was that the frail older persons would be exposed to too much stress during the interviews, and therefore it was important to be sensitive and not force the older persons to say more than they felt was possible. Permission to audiotape the interview was obtained from the informants. Different people interviewed the older persons and their significant others for ethical reasons such as integrity. If significant others asked what the older person had talked about, we could honestly say that we did not know. For this study, we looked at the pairs (older person together with their significant other), but the findings are presented at a group level to guarantee confidentiality.

\section{Findings}

Below, the narratives of the older persons, their significant others and the field notes are connected and presented in the shape of three themes that contrast their experiences and perceptions of existential loneliness. The themes were Meaningless waiting in contrast to lack of activities, Longing for a deeper connectedness in contrast to not participating in a social environment and Restricted freedom in contrast to given up on life. 


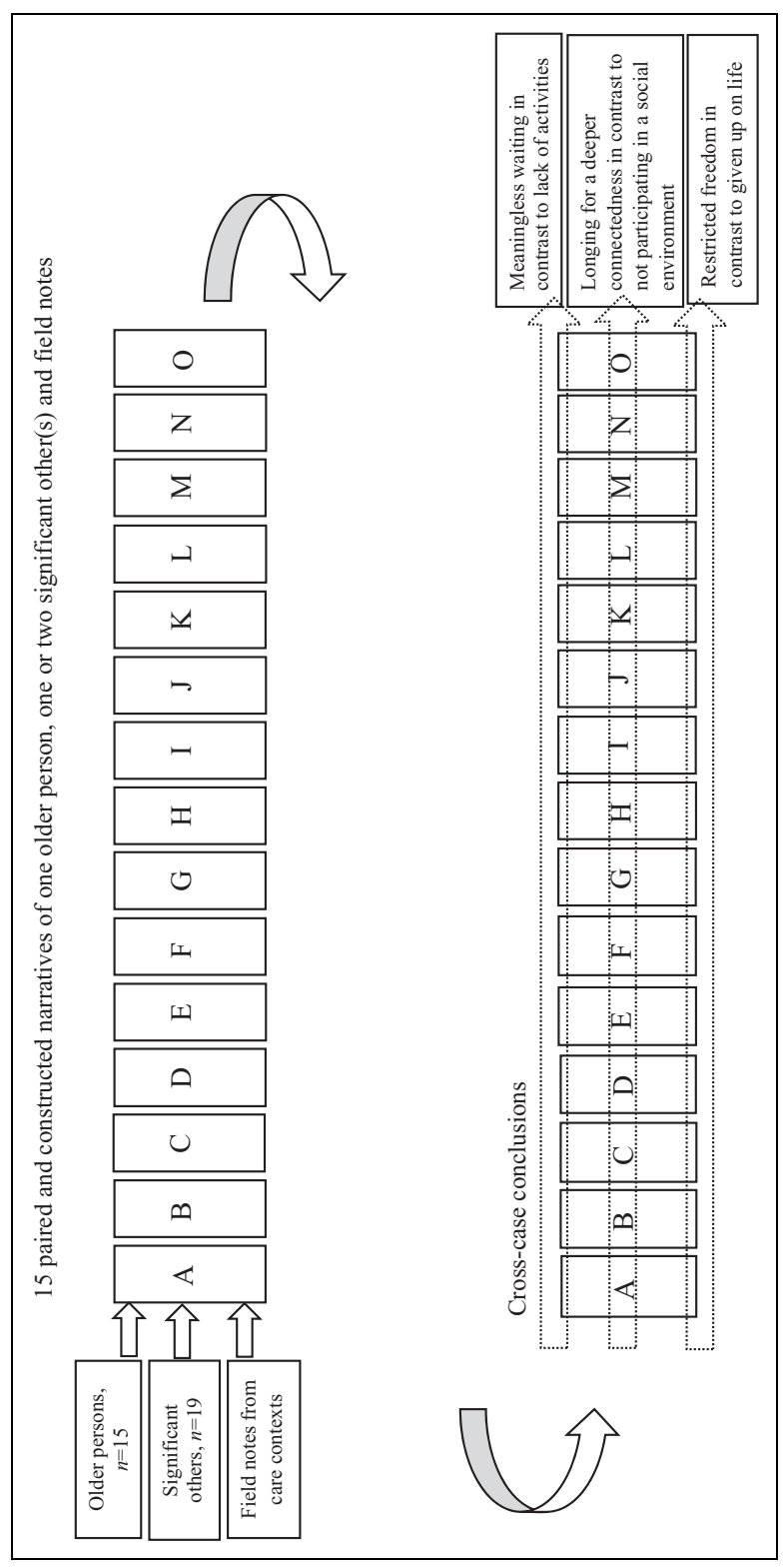

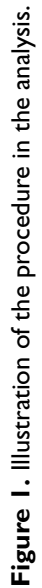




\section{Meaningless waiting in contrast to lack of activities}

The older persons describe how they are in a phase in life that consists of waiting. They are continuously waiting - for health care staff, for their significant others, for help getting to the toilet and for the possibility to go outside. They describe how waiting makes them feel that their life has become meaningless, empty and isolated, and such feelings give rise to existential loneliness. Significant others also relate the older persons' existential loneliness to feelings of meaninglessness and worthlessness but in relation to physical limitations and argue that it is the lack of suitable activities for older persons that triggers existential loneliness. In their endeavours, they try to encourage the older person to participate in activities and suggest that this could make existential loneliness decrease. However, the older persons do not express a longing for activities but rather a desire to be of importance to someone else. They describe how no one does things together with them but only for them. This theme is illustrated below by 'Martin'.

Cross-case narrative. Martin is 92 years old. He lives alone in a small apartment at an assisted living facility. $\mathrm{He}$ feels that his life has no meaning for anyone else anymore, which makes him experience existential loneliness. He feels that no one asks for his opinion or knowledge anymore. His significant others believe that Martin's existential loneliness relates to his physical limitations making him unable to take part in activities as he used to do. Martin spends most of his time in bed, where he has a clock, a TV and a music system. The clock is a constant reminder of how time passes even though Martin's life has become silent and characterised by waiting. His significant others perceive that Martin is doing well and that he is being taken good care of, while Martin himself thinks that his day is all about waiting for help from others. He feels that no one wants to do things together with him, only for him. Earlier in life, Martin experienced his home as a place for rest and tranquillity after work and travels. Now, his home has become a place for waiting rather than calmness. Before, he was the one everyone else was waiting for, and now he is the one who is waiting. For his significant others, these feelings of tiredness and waiting that Martin describes are disguised; instead they perceive that Martin needs something to do that keeps him busy, while Martin talks about the longing to be of importance to someone else.

\section{Longing for a deeper connectedness in contrast to not participating in a social environment}

The older persons describe how they feel excluded when they are among people whom they do not feel any connectedness with, or when they have no one to share essentials in life with. They describe how such situations give rise to existential loneliness. Significant others also relate the older persons' existential loneliness to emptiness due to losses of friends, family and places but rather they talk of the importance of having a social environment where it is possible to come together with people, since they believe that older persons experience existential loneliness if they do not socialise with others. Significant others describe how they often visit or call the older persons, but despite this, the older persons claim that few people, and sometimes no one, have deep and meaningful conversations with them. The conversations they refer to are about events in society, politics or news rather than daily things like the weather or when dinner is served. As the older persons gradually lose their long-term relationships with friends and family, significant others try to construct a new social environment for them. Significant others perceive that older persons' existential loneliness relates to their withdrawal and that they therefore end up without a social environment. This theme is illustrated below by 'Lilly'.

Cross-case narrative. Lilly is 83 years old and has lived in a nursing home ever since her husband died a couple of years ago. She feels that her life has become so hard since her husband died because she has no one to share difficult decisions with. An example of this is when she was at the hospital and had to decide 
whether she wanted a treatment or not. The doctors had discovered a tumour in her back and gave her different alternatives of treatment to choose between. She felt that she had no one to talk to about what she should do and she felt very lonely in her decision. Lilly experiences existential loneliness when she has no one to share moments like that with. She describes her experience like a new kind of loneliness, a loneliness that she has never felt before. Her significant others, however, perceive that Lilly's existential loneliness has to do with her being left out of the community at the nursing home and believe that Lilly could leave her room more often to spend time with the other residents. However, to be left out of the community is not something that Lilly talks about. She misses someone to share essentials in life with and that induces a feeling of existential loneliness. Lilly feels that her significant others have no interest in what interests her, namely art and music. Instead they suggest, for example, that she watches TV so that she has something more 'ordinary' to chat about, which they believe could help her integrate into the community at the nursing home.

\section{Restricted freedom in contrast to given up on life}

The older persons experience existential loneliness when they are not given the opportunity to express their wishes or choose by themselves in their everyday life, since they are dependent on other people's help. Significant others also relate the older persons' existential loneliness to dependency, but they do not talk about how the older person can no longer choose by themselves. They do not perceive the situation in a similar way; that is, they do not relate the older person's situation to restricted freedom but instead they relate the older person's existential loneliness to him or her having given up on life and lost his or her fighting spirit. This contrast between the attitude of the older person and that of their significant other also includes the material world. When the older person can no longer choose where to live, this gives rise to existential loneliness. Significant others, on the contrary, in their endeavours, want to find a comfortable home for the older person. They try to compensate the older person and facilitate things for them by helping them make decisions in daily life. However, the older persons feel that decisions are made for them and not together with them, which increases their existential loneliness. This theme is illustrated below by 'Jenny'.

Cross-case narrative. Jenny is 86 years old and lives alone in an apartment on the ground floor. She does not want to live in this apartment, but she feels that she has no other choice, and therefore she experiences existential loneliness. Jenny describes how throughout her life she has moved and changed her life depending on the circumstances, but now she can no longer choose where to be, and to feel like this is a new situation for her. The strategies she always used before when dealing with different situations in life are no longer possible. She feels that she cannot influence her daily life since she is dependent on other peoples' help. She can look out through the windows, but she cannot get outside. Her significant others instead relate Jenny's existential loneliness to how she has given up on life and not to her lost freedom. They believe that it was good for her to move and that those who got her to do so did well. The significant others perceive the apartment on the ground floor as a comfortable place for Jenny, and they believe that she is doing well at this place with windows in several directions. However, Jenny yearns for the place where she believed she could live for the rest of her days. If she had the opportunity to choose, she would move back again. She had to get rid of most of her material belongings when she moved. For Jenny, every belonging was a memory of her life and made her feel at home and anchored in her life, connected to the people she knew and the travelling she had done, while her significant others perceive that it was nice for her to get rid of a lot of her belongings. Jenny thinks it is so hard and she feels reluctant to stay at this place and does not recognise herself in her new life. Her significant others continue instead to talk of the importance of not giving up and they do not perceive the existential loneliness that Jenny feels when she has no possibility to choose for herself. 


\section{Discussion}

The findings from this study highlight contrasts between older persons' experiences and significant others' perceptions of existential loneliness. These contrasts were identified as (1) Meaningless waiting in contrast to lack of activities, (2) Longing for a deeper connectedness in contrast to not participating in a social environment and (3) Restricted freedom in contrast to given up on life. The findings can be seen in the light of the existential psychologist Emmy van Deurzen's ${ }^{30}$ description of different dimensions in a person's life world. First, the physical dimension 'Umwelt ${ }^{30}$ is characterised by different paces of life. In the present study, the older person's everyday life is characterised by waiting while their significant others often have a busy everyday life with family, friends and hobbies. Second, the social dimension 'Mitwelt ${ }^{30}$ is characterised by different processes. In the present study, the older persons have gradually lost their social environment, as they can no longer participate in such an environment, or have lost longterm relationships while their significant others often have, for instance, a social environment where they belong. Third, the personal dimension 'Eigenwelt ${ }^{30}$ is characterised by different roles. In the present study, the older persons, due to increasing bodily and mental limitations, are gradually losing their roles in the family and in society while their significant others have often retained a significant and meaningful role in the family and in society. This, in turn, reflects the different perspectives older people and their significant others have, and might explain why significant others have difficulties in taking the older persons' perspective on a deeper level.

One tension between frail older persons and their significant others occurs when they have different views of how to find meaning in life and thereby reduce existential loneliness. Significant others position themselves from their own perspective to determine what brings meaning in the older person's life. The results showed that the older persons' daily life was permeated by a continuous waiting, which resulted in a feeling that their life was meaningless. Significant others, instead, talked about the need for activities as a means to bring meaning to the older person's life. However, the older persons did not miss general activities but rather activities that gave a deeper sense of meaning. Frank $1^{9}$ describes how the ability to find meaning in existence is essential. If older persons have trouble finding meaning in their existence, there is a risk that their well-being will decrease, and it might decrease further if they are not given the opportunity to discuss their thoughts and feelings on a deeper level. ${ }^{31}$ In addition, other studies have shown that there is a link between, for example, lack of a meaningful life and depression. ${ }^{18}$ Bergum and Dossetor ${ }^{32}$ describe the importance of following a person closely and being genuinely interested in recognising the other person's wants and wishes. In addition, Martin Buber ${ }^{33}$ describes the importance of listening, not only to the spoken words but also to the facial expressions, the tone of voice and the unspoken words. ${ }^{33}$ When older persons no longer have the ability to create their own meaning, significant others and health care staff are essential resources. Since the older persons in this study particularly talked about the importance of being, and not doing, the challenge seems to be to account for the older person's need of being. In a study regarding nurse assistants' experiences of providing palliative care in municipal residential care settings, the findings reveal the dilemma of focusing on the being, that is, the relation, when the doing, that is, the task, has the highest priority. In addition, even if health care staff identify relational and existential needs, the organisation can be a barrier to meet those needs when the task-oriented actions are promoted. ${ }^{34}$ How to recognise and support a meaningful existence for people who are old and frail is thus something that needs to be given high priority in health care settings in order to promote well-being and a meaningful life.

Another tension between older persons and their significant others occurs when they have different views of how to feel connected in life. The results showed that significant others talked about 'being connected' in terms of having many social contacts and suggested more social activities in nursing homes to reduce existential loneliness. However, what prevented older persons from feeling connected was the lack of close relations where they could have deep conversations about meaningful topics. Other studies have revealed 
that there are periods in life when it is difficult to feel connected, for example, in combination with a severe illness ${ }^{14}$ or in a new context, something that has been expressed as 'feeling lonely in an unfamiliar place'. ${ }^{31}$ This is in line with the thoughts of Tillich, ${ }^{8}$ who has described the essence of how to feel connected in terms of either 'taking part' or 'being a part', where both aspects are needed in order to feel connected in life. The findings from our study show that the older persons are 'taking part' to a larger extent than 'being a part'. Even if the significant others endeavour to connect the older persons to a new social context, it may be difficult for the older persons to feel that they really are 'being a part'. The tension can also be understood in the light of the two parties being in different phases of life. The older persons are in their last phase in life, termed the 'ninth stage' by Erikson and Erikson. ${ }^{35}$ This stage is characterised as a balancing act between negative and positive aspects in life, where the negative aspects are increasingly in focus. ${ }^{35}$ For health care staff, the awareness of different phases in life is essential; otherwise it might be difficult for frail older persons to feel understood in their existential loneliness. For older persons to feel connected, connectedness in a deeper sense is vital.

Finally, yet another tension between the older persons and their significant others occurs when they have different views of freedom. The results showed that significant others often took on the role of decisionmaker for the older persons, perceiving that their help made it easier for the older person to manage his or her situation. However, for the older persons, existential loneliness arose when they felt that they no longer had a choice, when someone else took decisions for them and not together with them. Bergum and Dossetor $^{32}$ describe the role of significant others as being both that of a witness and a decision-maker. A witness is the one who 'knows something' and a decision-maker is the one who makes decisions for others. Significant others are important, both as witnesses and as decision-makers, and several studies highlight the importance of health care staff listening to significant others. ${ }^{4-6}$ However, there is a risk that this will be at the expense of the older person's voice. Not being listened to, or being unable to make one's voice heard, can result in feelings of powerlessness and lack of autonomy. ${ }^{32}$ Freedom of choice and freedom to influence one's own life are crucial aspects of autonomy. ${ }^{32}$ For significant others and health care staff, it is important to give older persons in need of care the opportunity to choose. Related to this is trust - a key value in the care of older persons. However, trust is a sensitive concept and grows in the presence of warm and empathic relations. ${ }^{33}$ An interview study by Tuominen et al. ${ }^{36}$ shows that it is not the life-changing events that make older persons feel autonomous and free but the daily events, such as control of one's bedtime, dressing, privacy and social life with relatives. Therefore, it seems important to preserve older people's independence and autonomy as far as possible, even concerning daily activities. How to involve frail older persons and make their voices and choices heard, when they are dependent on help from others, is a critical topic for ethical discussions among health care professionals.

\section{Methodological considerations}

There are limitations to this study. Even if it was the older persons themselves who gave the name/s of significant other(s), there is a risk that the significant others were not as close to the older persons as they needed to be in order to be able to interpret the older person's existential loneliness; this could potentially reduce credibility. ${ }^{37}$ However, all of the significant others characterised their relation to the older person as close or very close. Another limitation is that there is no clear consensus on the concept of existential loneliness. This may be seen as a weakness and a challenge to the credibility of our data. ${ }^{37}$ To counter this possibility, we introduced the concept to the informants in the written information and started the interviews, both with the older persons and their significant others, with the description of existential loneliness as a deeper feeling of loneliness. In addition, the interviews were done by two persons, one junior researcher and one senior researcher, who were both familiar with conversations about existential issues. Since the first author (H.L.) did the interviews with the significant others but not with the older persons, there was a risk 
that her pre-understanding of the significant others' views affected the interpretations of the older persons' views in the analysis. ${ }^{37}$ To minimise this risk, it was vital to listen to the interviews with the older persons and to read the transcriptions and the field notes. Another measure was to involve the second author (A.K.E.), who had not taken part in any of the interviews and therefore was not influenced by any interview beforehand. In addition, to safeguard confirmability, ${ }^{37}$ the four authors have different professional backgrounds, including caring science, theology, geriatric nursing and human geography. All four authors took part in the analysis and discussed the themes until an agreement was reached. In order for the researchers' interpretations to be verifiable, ${ }^{37}$ every step in the methods has been described and illustrated in a figure, extracts from raw data have been presented in a table and a narrative has been extracted to exemplify each theme. Concerning the transferability ${ }^{37}$ of the results, the informants in this study were identified within a Swedish health care context and the study had no participation of people with a migrant background, except for one of the significant others, which might limit the transferability. However, the informants were identified within different health care contexts to increase variation, which might strengthen the transferability to several settings.

\section{Clinical implications}

This study highlights the importance of listening to both the older persons' experiences and their significant others' perceptions, but in order to handle ethically difficult situations, where health care staff have to choose between alternative courses of action, it is of great importance to be aware of whose voice the care is based on. One way to bridge the gaps in these revealed contrasts could be a more relation-centred approach ${ }^{1}$ where both the frail older persons' story and their significant others' voices are given equal weight. In the present study, the findings reveal the importance of listening to both the frail older person and the significant other(s) rather than only one perspective or favouring one perspective over the other. Such knowledge is important in the provision of care and could be of use as a basis for ethical reflections in the care of older people and in the encounter with significant others.

\section{Conflict of interest}

The author(s) declared no potential conflicts of interest with respect to the research, authorship and/or publication of this article.

\section{Funding}

The author(s) disclosed receipt of the following financial support for the research, authorship, and/or publication of this article: This study is a part of the LONE study, funded by grants from the Vårdal Foundation and the Research Platform for Collaboration for Health at Kristianstad University, the Crafoord Foundation and the Greta and Johan Kock Foundation, and the Gyllenstiernska Krapperup Foundation.

\section{References}

1. Witkamp E, Droger M, Janssens R, et al. How to deal with relatives of patients dying in the hospital? Qualitative content analysis of relatives' experiences. J Pain Symptom Manage 2016; 52: 235-242.

2. Abrahamsson K, Bernard B, Magnabosco L, et al. The experiences of family members in the nursing home to hospital transfer decision. BMC Geriatr 2016; 16: 184.

3. Dyrstad DN, Laugaland KA and Storm M. An observational study of older patients' participation in hospital admission and discharge - exploring patient and next of kin perspectives. J Clin Nurs 2015; 24: 1693-1706.

4. Caspari S, Lohne V, Rehnsfeldt AW, et al. Dignity and existential concerns among nursing homes residents from the perspective of their relatives. Clin Nurs Stud 2014; 2: 22-33. 
5. Andershed B. Relatives in end-of-life care-part 1: a systematic review of the literature the five last years, January 1999-February 2004. J Clin Nurs 2006; 15: 1158-1169.

6. Funk L, Stajduhar K, Toye C, et al. Part 2: home-based family caregiving at the end of life: a comprehensive review of published qualitative research (1998-2008). Palliat Med 2010; 24: 594-607.

7. Bolmsjö I, Edberg AK and Sandman L. Everyday ethical problems in dementia care: a teleological model. Nurs Ethics 2006; 13: 340-347.

8. Tillich P. The courage to be. New Haven, CT: Yale Nota Bene, 2000.

9. Frankl VE. Man's search for meaning: an introduction to logotherapy. London: Hodder \& Stoughton, 1987.

10. Yalom ID. Existential psychotherapy. New York: Basic Books, 1980.

11. Mok E, Lau K, Lam W, et al. Health care professionals' perceptions of existential distress in patients with advanced cancer. $J$ Adv Nurs 2010; 66: 1510-1522.

12. Mayers AM and Svartberg M. Existential loneliness: a review of the concept, its psychosocial precipitants and psychotherapeutic implications for HIV-infected women. Br J Med Psychol 2001; 74: 539-553.

13. Ettema EJ, Derksen LD and van Leeuwen E. Existential loneliness and end-of-life care: a systematic review. Theor Med Bioeth 2010; 31: 141-169.

14. Sand L and Strang P. Existential loneliness in a palliative home care setting. J Palliat Med 2006; 9: $1376-1387$.

15. Nyström M. Aphasia - an existential loneliness: a study on the loss of the world of symbols. Int J Qual Stud Heal 2006; $1: 38-49$.

16. Sjöberg M, Beck I, Rasmussen B, et al. Being disconnected from life - meanings of existential loneliness as narrated by frail older people. Aging Ment Health 2018; 22: 1357-1364.

17. Larsson H, Rämgård $M$ and Bolmsjö I. Older persons' existential loneliness as interpreted by their significant others - an interview study. BMC Geriatr 2017; 17: 138.

18. van Wijngaarden E, Leget $\mathrm{C}$ and Goosensen A. Ready to give up on life: the lived experience of elderly people who feel life is completed and no longer worth living. Soc Sci Med 2015; 138: 257-264.

19. Karlsson M, Friberg F, Wallengren C, et al. Meanings of existential uncertainty and certainty for people diagnosed with cancer and receiving palliative treatment: a life-world phenomenological study. BMC Palliat Care 2014; 13: 28.

20. Allen $\mathrm{R}$ and Butler E. Addressing moral distress in critical care nurses: a pilot study. Int J Crit Care Emerg Med 2016; 2: 015 .

21. International Council of Nurses (ICN). The ICN code of ethics for nurses, http://www.icn.ch/images/stories/ documents/about/incode/ (2008, accessed 27 March 2018).

22. Sundström M, Edberg AK, Rämgård M, et al. Encountering existential loneliness among older people: perspectives of health care professionals. Submitted. 2017.

23. Lukas A, Niederecker T, Günther I, et al. Self- and proxy report for the assessment of pain in patients with and without cognitive impairment: experience gained in a geriatric hospital. Z Gerontol Geriatr 2013; 46: $214-221$.

24. Robertson S, Cooper C, Hoe J, et al. Proxy rated quality of life of care home residents with dementia: a systematic review. Int Psychogeriatr 2017; 29: 569-581.

25. Edberg AK and Bolmsjö I. Study protocol: exploring existential loneliness among frail older people. The development phase of the LONE study. Submitted. 2017.

26. Medical Research Council. Developing and evaluating complex interventions: new guidance. London: Medical Research Council, 2008.

27. Yin RK. Case study research - design and methods. Thousand Oaks, CA: Sage, 2003.

28. Braun V and Clarke V. Using thematic analysis in psychology. Qual Res Psych 2006; 3: 77-101.

29. WMA Declaration of Helsinki, http://www.wma.net/policies-post/wma-declaration-of-helsinki-ethical-principlesfor-medical-research-involving-human-subjects/ (2008, accessed 27 March 2018).

30. van Deurzen E. Existential counselling in practice. London: Sage, 1998. 
31. Österlind J, Ternestedt BM, Hansebo G, et al. Feeling lonely in an unfamiliar place: older people's experiences of life close to death in a nursing home. Int J Older People Nurs. Epub ahead of print 14 September 2017. DOI: 10.1111/opn. 12129 .

32. Bergum V and Dossetor J. Relational ethics: the full meaning of respect. Hagerstown, MD: University Publishing Group, 2005.

33. Buber M. The life of dialogue. New York: Routledge, 1955/2002.

34. Beck I, Törnquist A, Broström L, et al. Having to focus on doing rather than being - nurse assistants' experience of palliative care in municipal residential care settings. Int J Nurs Stud 2012; 49: 455-464.

35. Erikson EH and Erikson JM. The life cycle completed. New York; London: Norton, 1982/1998.

36. Tuominen L, Leino-Kilpi H and Suhonen R. Older people's experiences of their free will in nursing homes. Nurs Ethics 2016; 23: 22-35.

37. Shenton AK. Strategies for ensuring trustworthiness in qualitative research projects. Educ Inf 2004; 22: 63-75. 
IV 


\title{
FAMILY CARE ADVISORS' VIEWS ON EXISTENTIAL LONELINESS AND EXISTENTIAL SUPPORT PROVIDED TO INFORMAL CAREGIVERS TO OLDER PEOPLE
}

Helena Larsson, RN, PhD student ${ }^{1,2}$, Kerstin Blomqvist, RN, PhD, Professor ${ }^{2}$, Anna-Karin Edberg, RN, $\mathrm{PhD}$, Professor ${ }^{2}$, Christine Kumlien, RN, PhD, Professor ${ }^{1,3}$

${ }^{1}$ Faculty of Health and Society, Department of Care Science, Malmö University, Malmö, Sweden, ${ }^{2}$ Faculty of Health Sciences, Kristianstad University, Kristianstad, Sweden

${ }^{3}$ Department of Cardiothoracic and Vascular Surgery, Skåne University Hospital, Malmö, Sweden

\begin{abstract}
Background: Since 2009, Sweden has had in place a statutory obligation to provide support to those who care for relatives. The largest group of informal caregivers comprises those who provide care for older relatives. Research indicates a need to focus on and further understand existential loneliness and how it affects those who act as informal caregivers for relatives. A family care advisor could be a valuable resource for providing existential support to those who care for relatives. Aim: To investigate the family care advisors' views on existential loneliness and the existential support provided to those who provide care for their older relatives. Method: This study has a cross-sectional design. In order to reach all family care advisors, an electronic questionnaire was distributed by email $(n=349)$. The total number of responses was $n=120(36 \%)$. Data was analysed using descriptive statistics, being processed in SPSS. The possibility to freely write about other aspects was given for each part of the questionnaire. Results: The family care advisors (78\%) viewed existential loneliness as connected to thoughts about life and meaning. They provided existential support by talking to $(87 \%)$ and by visiting $(75 \%)$ the caregiving relatives. They provided contact to discussion groups (73\%) and they organized discussion groups (78\%) for the caregiving relatives. A total of 45 percent reported that they had time in their work to provide existential support, and 27 percent that they had knowledge of how to encounter existential loneliness. Conclusion: Family care advisors view existential loneliness as connected to thoughts about life and meaning, but they often lack the experience, knowledge and time to encounter existential loneliness. To have time and knowledge are important prerequisites to embracing a holistic view that includes acknowledging people's physical, social, emotional and existential needs. It is thus important to create opportunities for family care advisors to prioritize existential needs and to collaborate with other professionals regarding existential support.
\end{abstract}

Keywords: Family care advisor, existential loneliness, existential support, relative, informal caregiver, older people, questionnaire

Corresponding author: Helena Larsson, Faculty of Health Sciences, Kristianstad University, SE 29188 Kristianstad, Sweden, Phone: +46 44-25 03 947, email: helena.larsson@ hkr.se 


\section{INTRODUCTION}

In Sweden, a statutory obligation to provide support those who provide care to relatives has been in place since 2009 (1). The largest group of informal caregivers comprises relatives who care for older people (2). Previous research shows that relatives often experience the caring as stressful (3), and their own health can be affected (4), which has prompted this statute. In addition to stress, research shows that informal caregivers become easily isolated (5-6) and may experience loneliness of existential nature (7). Research also indicates the need to focus on and encounter the existential needs of those who act as informal caregivers to their relatives (7). Like many other parts of the world, one of Sweden's solutions to provide support to those who care for relatives is to have family care advisors. Their mission is to coordinate and provide support specifically targeted to those people who care for relatives (8). However, it is unclear if and how the family care advisors perceive and support relatives' existential needs.

Every municipality in Sweden is required to employ a family care advisor. This role is intended to support those who care for older relatives or families with children who have disabilities or families with a family member with mental illness/addiction (8). The family care advisor's role is often twofold - to provide direct support to informal caregivers in the form of emotional support and to inform them of, for example, what other support is available. Many also have a strategic role to develop caregiver support in their municipality (9). The support can be directed to the caregiver, such as education, support groups or wellness activities. However, the support can also be indirect aimed at the relative who receives the care, such as service in the home, daily activities arranged by the municipality, or respite care at a nursing home. The caregivers can contact the family care advisor, but contact is usually established by the family care advisor getting in contact with the caregivers by being present at meetups for the caregivers (8). A study from Canada that includes interviews with family care advisors showed that the advisors saw themselves as a link between the family/relative and the healthcare system. It also showed that they collaborated with many different professionals and that their focus was the family/relative and their needs (10). These needs can be existential in nature and are often associated with thoughts about the fundamental issues of human life such as our search for meaning and purpose in life, our need to connect with others and belong, and our awareness of dying and death (11). In times of fundamental questioning, existential loneliness can emerge. A concept analysis illuminated existential loneliness as a phenomenon that occurs when perceiving oneself as separated and disconnected from others and the universe, and this may bring out feelings of isolation, alienation, emptiness, and abandonment (12). For example, spouses who cared for a frail partner late in life experienced existential loneliness as an inner struggle when feeling forced to make difficult decisions regarding their partner's life and when experiencing the permanent loss of the other (7). However, existential loneliness is also elucidated as a phenomenon that is a part of life, part of what it means to be human (11), and a part of a process of inner growth (13). To ease existential suffering, it is important to recognize, acknowledge, and share the experience of existential loneliness with others $(7,14-15)$.

Existential loneliness can emerge when one cares for a frail older family member - a situation that can be described as "double-edged". The role is considered self-chosen and wanted (4), but it is also demanding and unavoidable (7). Having to act as an expert while at the same time be a protector (16) can be rewarding yet difficult (6). An empirical study from Sweden that features interviews with significant others who cared for an older family member showed that they viewed their role as that of a devoted companion until the end of life. A prerequisite for being able to be that companion is access to professional care and support when one's own resources and strengths falter (4). A review of 17 empirical studies shows how people who live in the presence of the death of a relative need continual support in existential matters. In the study, only a few interventions that focused on how relatives' existential concerns were met were reported (17). The findings from a review that explored the needs of relatives who cared for an older person living at home reinforced that they needed emotional support from professionals and to develop coping strategies to deal with emotional stress (18). Similar results were shown in a review regarding spouses in South Korea (19). The aforementioned studies indicate the need to focus on and encounter existential needs among those who act as informal caregivers to their relatives. It is essential to know more about the views of family care advisors, as they could be a valuable resource in observing and providing existential support to people who give care to relatives. Such 
knowledge could be used for developing interventions to support family care advisors in their work. Therefore, the aim of this study was to investigate the family care advisors' views on existential loneliness, and of the existential support provided to those who care for older relatives.

\section{METHOD}

This current study has a cross-sectional design (20), and is a part of a larger research project about existential loneliness, the LONE study, RR2-10.2196/1307 (21). The LONE study is in the development phase of designing a complex intervention (22). One study in the project focuses on experiences of existential loneliness among people who care for a frail spouse ( $\geq 75$ years old) late in life (7). During the analysis of the interviews with the spouses, a question emerged about what kind of support the caregiving spouses have from the municipality which are specifically aimed at supporting their existential needs, and this question led us further to the current study.

\section{Sample and Setting}

The inclusion criteria was family care advisors whose mission is to support those who care for older relatives. The family care advisors were identified by searching 290 municipality websites, and a questionnaire was distributed to all identified email addresses $(n=349)$. Eight $(n=8)$ of the questionnaires did not reach any respondents and an additional seven $(n=7)$ questionnaires were excluded because the respondents stated that their mission did not concern people who provided care to older relatives. After two reminders, the total number of responses was $n=120(36 \%)$.

\section{Data collection and Procedure}

The questionnaire was specifically developed for the current study based on pre-knowledge from previous studies in the LONE study (21) and from available information from the Swedish Family Care Competence Centre (8). The questionnaire consisted of four parts, in which the first part involved statements about existential loneliness. The second part consisted of statements about who in particular was in focus for the family care advisors' support, and the third part concerned actions undertaken to provide existential support. The fourth and final part was about the family care advisors' work conditions for providing existential support. The family care advisors were asked to respond to a statement by rating their answer on a four-graded Likert scale (20) ranging from 'totally disagree' (rate 1) to 'totally agree' (rate 4). The possibility to freely write about other aspects was given for each part of the questionnaire.

Attached to the questionnaire was a letter with information about the ongoing LONE study (21): "We turn to you to gain an overview of what kind of support you provide as family care advisor to relatives of frail older people regarding existential needs in general and existential loneliness in particular". Existential loneliness was explained as a deep feeling of loneliness, as in, being alone and confined to oneself and as an experience that seems to emerge when one is in a particularly vulnerable situation and when facing the loss of friends and family members.

The questionnaire was distributed through an electronic evaluation system provided by Kristianstad University. The questionnaire was pilot tested by letting one family care advisor read and reflect upon the statements with the first author. In addition, members in the research team reflected and discussed the contents of the questionnaire, and some adjustments were made. The questionnaire was distributed in February 2019 and closed after seven weeks. Two reminders were sent to non-responders. The second reminder was distributed at a different day and time of the week than the first reminder.

\section{Analysis}

The data was processed in The Statistical Package for the Social Sciences (SPSS) version 24.0 (IBM, Corp., Armonk, NY, USA). Descriptive statistics were used, and the median and percentages were determined. Freely written answers were structured and sorted in relation to each area and summarized. Statements were chosen from each area to give examples of the respondents' free writing.

\section{Ethical aspects}

The study was approved by the Ethical Review Board in Lund, Sweden (Reg.no. 2018/422). The attached letter explained that the respondents' participation was anonymous and that their answers would not be possible to track. If they chose to answer the questionnaire, this meant that they agreed to participate in the study. 


\section{RESULTS}

The respondents $(n=120)$ were five men and 115 women, aged between 34 and 66 years old (Md 55 years). The respondents' length of time working as family care advisors ranged from between 3 months and 27 years, (Md 7 years). The respondents had either no co-workers or possibly one co-worker with similar tasks as themselves. The family care advisors had various qualifications: registered nurse (13\%), social worker $(9 \%)$, occupational therapist $(7 \%)$, behavioral therapist $(8 \%)$, or other $(63 \%)$. Other represented fields were in gerontology (43\%), communication and support (34\%), management and society (9\%), psychology and social work (9\%), and philosophy and existentialism (5\%). For description of demographics, see Table 1.

\section{INSERT TABLE 1 ABOUT HERE}

\section{Family care advisors' view on existential loneliness}

Of the family care advisors 78 percent reported that 'life' and 'meaning' had to do with existential loneliness while 'dying', 'death', 'losses and loneliness', 'lacking relationships' were reported to be connected to existential loneliness by 62-63 percent. Fewer respondents (50\%) reported that 'freedom', 'autonomy' and 'self-determination' were connected to existential loneliness (see Table 2).

In the written comments, the respondents stated that other aspects of existential loneliness were feeling a lack of belonging, feelings of grief and hopelessness, dwelling on notions of life and existence, feeling lonely despite having other people around, and existential loneliness as being part of life. For example, one respondent wrote, "I associate existential loneliness with the lack of hope, meaning and sense of coherence in life".

\section{Receivers of support provided}

The majority $(75 \%)$ of the family care advisors provided existential support to relatives whose partner lived at home, in a nursing home (71\%), or had respite care $(69 \%)$. Fewer respondents provided support in existential needs to relatives whose partner had died (30\%), to professionals (27\%), or to volunteers who encountered relatives (18\%) (see Table 2 ).

In the written comments, the respondents stated that they provided support to relatives who needed it, irrespective of the circumstances in their relationship with the person they cared for. For example, one respondent wrote, "I provide support to all relatives (adults) regardless of their relationship with the one they care for. They can be adult children to parents, siblings, good friends and so on".

\section{Actions connected to existential support}

The majority of the family care advisors provided existential support by talking to (87\%) and by visiting $(75 \%)$ the caregiving relatives. They provided contact to discussion groups $(73 \%)$ and they organized discussion groups $(78 \%)$ for the caregiving relatives. Fewer respondents $(37 \%)$ provided lectures for relatives about existential needs. Offering education to professionals about existential support was reported by 12 percent (see Table 2).

In the written comments, the respondents referred to organizing courses for caregiving relatives that included group discussions about specific topics. In addition, they collaborated with others, used soft massage, and had visiting work. For example, one respondent wrote, "I arrange study circles for relatives so that they have the opportunity to reflect on their choices in life, recovery, and how everyday life can be managed".

\section{Conditions for providing support}

A total of 45 percent reported that they had time in their work to provide existential support, and 44 percent had experience of encountering existential loneliness. Fewer respondents (27\%) stated that they 
had knowledge of about how to encounter existential loneliness, and 16 percent of the respondents reported that they had enough knowledge to provide existential support to professionals and to volunteers (14\%). A few respondents $(4 \%)$ reported that they provided support outside their working hours (see Table 2).

In the written comments, the respondents wrote that they wanted to reach out to more relatives, needed further time and knowledge, and wanted to collaborate more with others. They also wished that they did not have to be alone in their role and that they could do more for the relatives. For example, one respondent wrote about own needs: "[I] want to say what I miss: A sounding board, someone to talk to after difficult conversations." Another respondent wrote about organizational needs: "More teamwork! The whole situation around a relative needs much more teamwork to be able to access and help people for change and improvement."

In addition, in the written comments, the respondents expressed wanting to have more time to reach out to relatives. For example, one respondent wrote:

I wish that I had the opportunity to provide support for a longer time after someone has lost a family member, without being limited to a couple of follow-up conversations. In the grief, we shall refer to churches or to the Red Cross. Many say "that's when the crisis culminates", but we have to let go.

\section{INSERT TABLE 2 ABOUT HERE}

\section{DISCUSSION}

The results indicate that the family care advisors have an idea of what existential loneliness is, but they often lack the experience and knowledge to encounter existential loneliness. For example, a majority of the family care advisors connected 'life' and 'meaning' to existential loneliness. However, less than half of the family care advisors reported that they had experience of encountering existential loneliness and even fewer, only a fifth, reported that they had the knowledge to encounter existential loneliness. Highlighted areas in the guidelines for the family care advisors' mission (23) are physical and social support in everyday life. However, the texts about of existential needs and support in existential issues are somewhat unclear in the guidelines even though research claims that existential needs are a part of everyday life (24). A study in a healthcare context showed that it is demanding for professionals to face existential loneliness (15), and Udo (25) concludes that practitioners need awareness of the importance of existential issues. Both studies highlight the importance of drawing attention to humans' fundamental questions, such as those regarding life and meaning, in order to alleviate existential suffering $(15,25)$. It is important to create opportunities for family care advisors to gain knowledge and experience about how existential loneliness can be encountered and alleviated. This increases their ability to provide support to those caring for older relatives, not only in terms of their social and physical needs but also their existential needs.

Relatives who have lost their life-companion may have difficulty finding support for their existential needs. The results indicate that the focus of the family care advisors is often relatives who live together with their partner, but only a third of the family care advisors in our study reported that they provided support to relatives who had lost their partner through death. This could be seen as a lack in provision of support to relatives. Moreover, research illuminates the importance of support when losing a lifecompanion $(7,26)$. This suggests that further knowledge is needed about how and under which circumstances relatives receive support, particularly in terms of their existential needs when their significant other has died. The results indicate the need for an extended mission so that family care advisors can be given more time to include those who are grieving over a prolonged period.

The family care advisors provided support to relatives by having conversations with them and visiting them at home. However, less than half of the family care advisors reported that they had enough time in their work to provide existential support, and in addition, some reported that they provided support outside working hours. One prerequisite for having a genuine and trustful conversation is to have enough time. Studies both in healthcare and social work fields mention the shortage of time (27), effective time, use of time, cost-effective time (28). This is in glaring contrast to philosophers as Buber's (29) reasoning about how time is important for having genuine and present conversations. It is important that "talking 
to relatives" becomes a genuine and present conversation - what Buber (29) calls a meeting between $I$ and Thou rather than $I$ and It. Moreover, research regarding alleviating existential loneliness shows that having genuine conversations is key for encountering existential needs (14). For further research, it is important to know more about the relation between time and conversations to satisfy existential needs among relatives who care for older people.

\section{Methodological limitations}

There are some limitations to this study. There is a risk that the respondents did not understand the attached letter with information or the statements in the questionnaire (20). To minimize this risk, the letter and the questionnaire were reviewed and answered by a family care advisor as well as the research team before it was distributed, and some adjustments were made. A further limitation is that the data only allowed descriptive statistics due to the small sample size. Also, despite the two reminders, the response rate was quite low and it could be argued that the sample is not representative for the whole group of family care advisors. Nevertheless, the distribution of respondents was similar to a Swedish national report from 2014 (9) regarding age and gender. In addition, the sample represented smaller to larger municipalities which indicate a representative sample (2).

\section{Conclusions}

Family care advisors view existential loneliness as connected to thoughts about life and meaning, but they express that they often lack the experience, knowledge and time to encounter existential loneliness. To have time and knowledge are important prerequisites to embracing a holistic view that includes acknowledging people's physical, social, emotional and existential needs. It is thus important to create opportunities for family care advisors to prioritize not only social and physical needs but also existential needs and to collaborate with other professionals regarding existential support.

\section{Acknowledgements}

We are most grateful to the family care advisors who took the time and effort to report their views. In addition, a special thanks go to the family care advisor who tested the questionnaire before it was distributed.

\section{Funding}

This study is a part of the LONE project, which is funded by grants from the Vardal Foundation and the Research Platform for Collaboration for Health at Kristianstad University, the Crafoord Foundation, the Greta and Johan Kock Foundation and the Gyllenstiernska Krapperup Foundation.

\section{Authors' contribution}

H.L., K.B., A-K.E., and C.K. designed the study and developed the questionnaire. All authors were involved in the analysis. All authors have contributed substantially to the final manuscript and approved it for publication.

\section{Declaration of interest statement}

The authors declare that they have no competing interests. 


\section{References}

1. Swedish Social Services Act 2001:453, 5:10. https://www.riksdagen.se/sv/dokumentlagar/dokument/svensk-forfattningssamling/socialtjanstlag-2001453_sfs-2001-453

2. SCB, Statistics Sweden. Population statistics. 2018, August 2019 https://www.scb.se/hitta-statistik/statistik-efter-amne/befolkning/befolkningenssammansattning/befolkningsstatistik/

3. Stoltz P, Udén G, Willman A. Support for family carers who care for an elderly person at home - a systematic literature review. Scand J Caring Sci 2004; 18(2):111-9.

4. Andersson M, Ekwall AK, Hallberg IR, Edberg AK. The experience of being next of kin to an older person in the last phase of life. Palliat Support Care 2010; 8(1):17-26.

5. Neri A, Yassuda MS, Fortes-Burgos AC et al. Relationships between gender, age, family, conditions, physical and mental health, and social isolation of elderly caregivers. Int Psychogeriatr 2012; 24(3):472-83.

6. Greenwood N, Smith R. The oldest carers: A narrative review and synthesis of the experiences of carers aged over 75 years. Maturitas 2016; 94:161-72.

7. Larsson H, Rämgård M, Kumlien C, Blomqvist K. Spouses' existential loneliness when caring for a frail partner late in life - A hermeneutical approach. Submitted.

8. The Swedish Family Care Competence Centre. 2019, August https://www.anhoriga.se/

9. Winqvist M. Anhörigkonsulentens arbete och yrkesroll. Resultat från en enkätundersökning. [the Family care advisor's work and professional role]. Report 2014:1, the Swedish Family Care Competence Centre, Sweden.

10. Goodridge D, Isinger T, Rotter T. Patient family advisors' perspectives on engagement in health-care quality improvement initiatives: Power and partnership. Health Expect 2018; 21:379-86.

11. Yalom ID. Existential psychotherapy. 1980, Basic Books, New York.

12. Bolmsjö I, Tengland P-A, Rämgård M. Existential Loneliness: An attempt at an analysis of the concept and the phenomenon. Nurs Ethics 2018; 1-16.

13. Ettema EJ, Derksen LD, van Leeuwen E. Existential loneliness and end-of-life care: A systematic review. Theor Med Bioeth 2010; 31:141-69.

14. Sjöberg M, Edberg AK, Rasmussen BH, Beck I. Being acknowledged by others and bracketing negative thoughts and feelings: Frail older people's narrations of how existential loneliness is eased. Int J Older People Nurs 2018; 14:12213.

15. Sundström M, Edberg AK, Rämgård M, Blomqvist K. Encountering existential loneliness among older people: perspectives of health care professionals. Int J Qual Stud Health Wellbeing 2018; 13:1474673.

16. James I, Andershed B, Ternestedt BM. The encounter between informal and professional care at the end of life. Qual Health Res 2009; 19(2):258-71.

17. Melin-Johansson C, Henoch I, Strang S, Browall M. Living in the presence of death: an integrative literature review of relatives' important existential concerns when caring for a severely ill family member. Open Nurs $J$ 2012; 6:1-12.

18. Silva AL, Teixeira HJ, Teixeira MJC, Freitas S. The needs of informal caregivers of elderly people living at home: an integrative review. Scand J Caring Sci 2013; 27:792-803.

19. Oh Y, Han E. Review of studies on spousal caregivers of frail spouses in South Korea. Int Soc Work 2019; 62(2):529-48.

20. Polit DF, Beck CH. Nursing Research. Generating and Assessing Evidence for Nursing Practice. 2017, Wolters Kluwer $10^{\text {th }}$ edition, Philadelphia.

21. Edberg AK, Bolmsjö I. Exploring existential loneliness among frail older people as a basis for an intervention: Study protocol of the development phase of the LONE study. RR210.2196/1307, JMIR Res Protoc 2019; Doi:10.2196/13607.

22. MRC, Medical Research Council. Developing and Evaluating Complex Interventions: New Guidance. 2008, Medical Research Council, London.

23. The National Board of Health and Welfare, Sweden. Support to Relatives - Guiding principles to the municipalities regarding Social Services Act 2001:453, 5:10.

24. Pejner MN, Ziegert K, Kihlgren A. Trying to cope with everyday life - emotional support in municipal elderly care setting. Int J Qual Stud Health Well-being 2012; 13:1-7. 
25. Udo C. The concept and relevance of existential issues in nursing. Eur J Oncol Nurs 2014; $18: 347-54$

26. Førsund LH, Skovdahl K, Kiik R, Ytrehus S. The loss of a shared lifetime: a qualitative study exploring spouses' experiences of losing couplehood with their partner with dementia living in institutional care. J Clin Nurs 2015; 24:121-30.

27. Sundström M, Blomqvist K, Edberg AK, Rämgård M. The context of care matters: Older people's existential loneliness from the perspective of healthcare professionals - A multiple case study. Int J Older People Nurs 2019; 12234.

28. Duffield C, Gardner G, Catling-Paull C. Nursing work and the nursing time. J Clin Nurs 2008; 17:3269-74.

29. Buber M. Jag och Du [I and Thou]. 1994, Dualis Förlag, Ludvika. 
Table 1. Demographics of the respondents

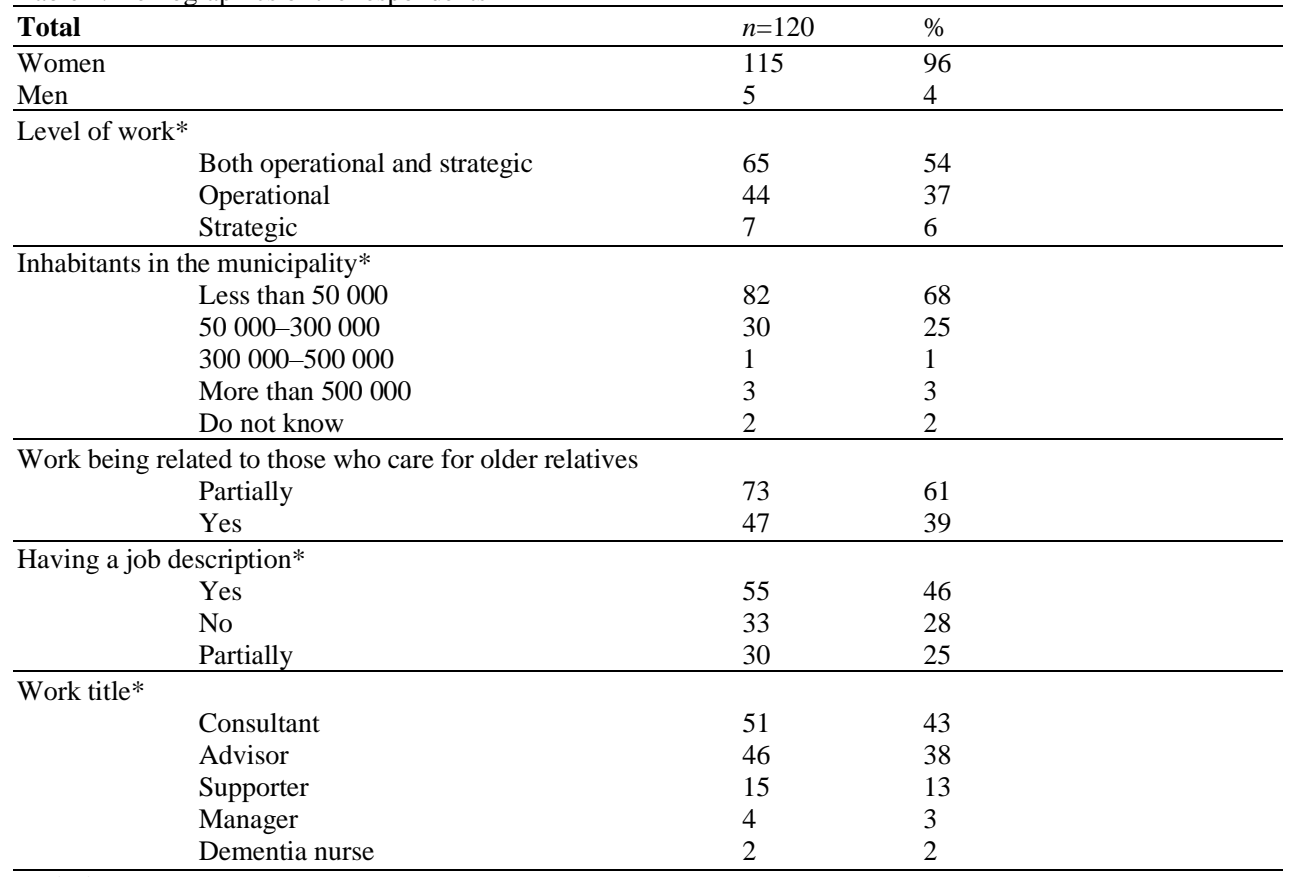

*Missing $n=2-4$ 
Table 2. Statements in the questionnaire, $n=120$

Median 'Totally agree' \%

In your work, existential loneliness (a deeper feeling of loneliness) is connected to:

\begin{tabular}{|c|c|c|}
\hline Life, meaning $^{1}$ & 4 & 78 \\
\hline Dying, death, loss ${ }^{1}$ & 4 & 62 \\
\hline Loneliness, lack of relationships ${ }^{1}$ & 4 & 63 \\
\hline Freedom, autonomy, self-determination ${ }^{1}$ & 4 & 50 \\
\hline \multicolumn{3}{|l|}{ In your work, existential support is provided to: } \\
\hline Persons who live together with the relative they care for ${ }^{1}$ & 4 & 75 \\
\hline Persons whose relative lives at a nursing home ${ }^{1}$ & 4 & 71 \\
\hline Persons whose relative has respite care ${ }^{1}$ & 4 & 69 \\
\hline Persons whose relative has died ${ }^{1}$ & 3 & 30 \\
\hline Professionals who encounter relatives ${ }^{2}$ & 3 & 27 \\
\hline Volunteers who encounter relatives $^{2}$ & 2 & 18 \\
\hline
\end{tabular}

In your work, the following actions are connected to existential support:

Talk to relatives ${ }^{1}$

Organize discussion groups ${ }^{1}$

Visit relatives $^{1}$

\begin{tabular}{ll}
\hline Provide contact to discussion groups & 1 \\
\hline
\end{tabular}

\begin{tabular}{ll} 
Provide contact to practical support $^{1}$ & 4 \\
\hline
\end{tabular}

Provide contact to professional therapist ${ }^{1}$

Provide written information $^{1}$

Provide lectures to relatives about existential needs ${ }^{2}$

Provide support to professionals in existential needs such as existential loneliness ${ }^{2}$

Provide support to volunteers in existential needs such as existential loneliness ${ }^{3}$

Provide education to professionals about existential support ${ }^{3}$

$4 \quad 87$

$4 \quad 78$

$4 \quad 75$

$4 \quad 73$

463

$4 \quad 56$

$3 \quad 47$

$3 \quad 37$

$2 \quad 18$

$2 \quad 14$

In your work, you have the following conditions to provide existential support:

Time in your work ${ }^{1}$

Experience of encounter existential loneliness ${ }^{1}$

$3 \quad 45$

Knowledge to provide existential support to relatives ${ }^{1}$

Knowledge to encounter existential loneliness ${ }^{1}$

Knowledge to provide existential support to professionals ${ }^{1}$

Knowledge to provide existential support to volunteers ${ }^{1}$

$3 \quad 44$

$3 \quad 27$

$3 \quad 18$

216

Not enough time to provide existential support, but you provide support outside working hours ${ }^{1}$

${ }^{1}$ Missing $n=1-10,{ }^{2}$ Missing $n=11-20,{ }^{3}$ Missing $n=21-25$ 


\section{Malmö University Health and Society Doctoral Dissertations}

Ross, M. W. Typing, doing and being. A study of men who have sex with men and sexuality on the Internet. 2006:1

Stoltz, P. Searching for meaning of support in nursing. A study on support in family care of frail aged persons with examples from palliative care at home. 2006:2

Gudmundsson, P. Detection of myocardial ischemia using real-time myocardial contrasts echocardiograpy. 2006:3

Holmberg, L. Communication in palliative home care, grief and bereavement. A mother's experiences. 2007:1

Ny, P. Swedish maternal health care in a multiethnic society - including the fathers. 2007:2

Schölin, T. Etnisk mångfald som organisationsidé. Chefs- och personalpraktiker i äldreomsorgen. 2008:1

Svensson, O. Interactions of mucins with biopolymers and drug delivery particles. 2008:2

Holst, M. Self-care behaviour and daily life experiences in patients with chronic heart failure. 2008:3

Bahtsevani, C. In search of evidence-based practices. Exploring factors influencing evidence based practice and implementation of clinical practice guidelines. 2008:4

Andersson, L. Endocytosis by human dendritic cells. 2009:1

Svendsen, I. E. In vitro and in vivo studies of salivary films at solid/liquid interfaces. 2009:2

Persson, K. Oral health in an outpatient psychiatric population. Oral status, life satisfaction and support. 2009:3

Hellman, P. Human dendritic cells. A study of early events during pathogen recognition and antigen endocytosis. 2009:4

Baghir-Zada, R. Illegal aliens and health (care) wants. The cases of Sweden and the Netherlands. 2009:5

Stjernswärd, S. Designing online support for families living with depression. 2009:6

Carlsson, A. Child injuries at home - prevention, precautions and intervention with focus on scalds. 2010:1

Carlson, E. Sjuksköterskan som handledare. Innehåll i och förutsättningar för sjuksköterskors handledande funktion i verksamhetsförlagd utbildning - en etnografisk studie. 2010:2

Sinkiewicz, G. Lactobacillus reuteri in health and disease. 2010:3

Tuvesson, H. Psychiatric nursing staff and the workplace. Perceptions of the ward atmosphere, psychosocial work environment, and stress. 2011:1

Ingvarsdotter, K. Mental ill health and diversity. Researching human suffering and resilience in a multicultural context. 2011:2

Hamit-Eminovski, J. Interactions of biopolymers and metal complexes at biological interfaces. 2011:3 
Mellgren, C. What's neighbourhood got to do with it? The influence of neighbourhood context on crime and reactions to crime. 2011:4

Annersten Gershater, M. Prevention of foot ulcers in patients with diabetes mellitus. Nursing in outpatient settings. 2011:5

Pooremamali P. Culture, occupation and occupational therapy in a mental care context- the challenge of meeting the needs of Middle Eastern immigrants. 2012:1

Gustafsson A. Aspects on sepsis: treatment and markers. 2012:2

Lavant, E. Multiplex HLA-DR-DQ genotyping. For genetic epidemiology and clinical risk assessment. 2012:3

Wangel, A-M. Mental ill-health in childbearing women. Markers and risk factors. 2012:4

Scaramuzzino, R. Equal opportunities? - A cross-national comparison of immigrant organisations in Sweden and Italy. 2012:5

Ivert, A-K. Adolescent mental health and utilisation of psychiatric care - The role of parental country of birth and neighbourhood of residence 2013:1

Znamenskaya, Y. Effect of hydration on thermodynamic, rheological and structural properties of mucin. 2013:2

Andersson, F. The female offender. Patterning of antisocial and criminal activity over the life-course. 2013:3

Lindroth, M. Utsatthet och sexuell hälsa - en studie om unga på statliga ungdomshem. 2013:4

Hulusjö, A. The multiplicities of prostitution experience - narratives about power and resistance. 2013:5

Falk, M. Direct electron transfer based biofuel cells. Operation in vitro and in vivo. 2014:1

Finnbogadóttir, H. Exposure to domestic violence during pregnancy. Impact on outcome, midwives' awareness, women's experience and prevalence in the south of Sweden. 2014:2

Fagerström, A. Effects of surfactant adjuvants on barrier properties of plant leaf cuticle. 2014:3

Lamberg, P. Design and characterization of direct electron transfer based biofuel cells including tests in cell cultures. 2014:4

Richert, T. Överdoser, försörjningsstrategier och riskhantering - livsvillkor för personer som injicerar narkotika. 2014:5

Örmon, K. Experiences of abuse during the life course. - Disclosure and the care provided among women in a general psychiatric context. 2014:6

Sjöblom, I. Planerade hemförlossningar i Norden - kvinnors och barnmorskors perspektiv. 2014:7

Albèr, C. Humectants and Skin - Effects of hydration from molecule to man. 2015:1

Kisch M., A. Allogeneic stem cell transplantation. - Patients' and sibling donors' perspectives. 2015:2

Weiber, I. Children in families where the mother has an intellectual or developmental disability - incidence, support and first person perspectives. 2015:3 
Schlyter, M. Myocardial infarction, Personality factors, Coping strategies, Depression and Secondary prevention 2016:1

Carlström, C. BDSM - Paradoxernas praktiker. 2016:2

El-Schich, Z. Novel imaging technology and tools for biomarker detection in cancer. 2016:3

Boonsatean, W. Living with type 2 diabetes in Thai population: Experiences and socioeconomic characteristics. 2016:4

Vejzovic, V. Going through a colonoscopy and living with inflammatory bowel disease: Children's and parents' experiences and evaluation of the bowel cleansing quality prior to colonoscopy. 2016:5

Isma, G.E. Overweight and obesity in young children: Preventive work in child health care with focus on nurses' perceptions and parental risk factors. 2016:6

Brännvall, M. Frigörelse med förhinder - Om polisanmälan när kvinnor tar sig ur mäns våld i nära relationer. 2016:7

Pankratov, D. Self-charging biosupercapacitors. 2016:8

Guidi, P. Social work assessment of families with children at risk: Similarities and differences in Italian and Swedish public social services. 2016:9

Jakobsson, J. The process of recovery after colorectal cancer surgery: Patients' experiences and factors of influence. 2017:1

Gerell, M. Neighborhoods without community. Collective efficacy and crime in Malmö, Sweden. 2017:2

Wierzbicka, C. New fractionation tools targeting elusive post-translational modifications. 2017:3

Afzelius, M. Families with parental mental illness: Supporting children in psychiatric and social services. 2017:4

Nordgren, J. Making drugs ethnic - Khat and minority drug use in Sweden. 2017:5

Nilsson, E-L. Parental socialization and adolescent offending. 2017:6

Sixtensson, J. Härifrån till framtiden. Om gränslinjer, aktörskap och motstånd i tjejers vardagsliv. 2018:1

Vasiljevic, Z. Ambulatory risk assessment and intervention in the prison services. Using Interactive Voice Response to assess and intervene on acute dynamic risk among prisoners on parole. 2018:2

González Arribas, E. Flexible and transparent biological electric power sources based on nano-structured electrodes. 2018:3

Svalin, K. Risk assessment of intimate partner violence in a police setting. Reliability and predictive accuracy. 2018:4

Andersson, M. Hate crime victimization: consequences and interpretations. 2018:5

Djampour, P. Borders crossing bodies. The stories of eight youth with experience of migrating 2018:6 
Yeung, S.Y. Stimuli-responsive lipid bilayer mimics for protein, virus and cell recognition. 2018:7

Holst-Hansson, A. On a journey for survival: everyday life during radiation therapy from the perspectives of women with breast cancer and their families. 2018:8

Berlin Hallrup, L. Experiences of Everyday Life and Participation for People with Intellectual Disabilities - From four Perspectives. 2019:1

Aleksejeva, O. Blue copper proteins as bioelements for bioelectronics devices. 2019:2.

Wendel, L. Dokumentation, profession och hälso- och sjukvård. Rättsliga perspektiv. 2019:3

Larsson, H. Existentiell ensamhet hos sköra äldre personer - ett närståendeperspektiv. 2020:1

The publications are available on-line.

See www.mah.se/muep 

